
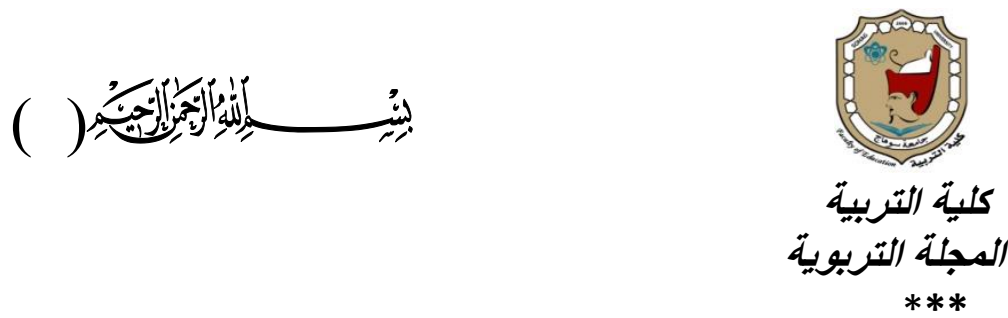

فاعلية إستراتيجية مقترحة قائمة على التعلم بالخبرات المباشرة في تدريس التربية الفنية لتنمية مهارات المات الأداء الفني لدى التي المبات تلاميذ المرحلة المتوسطة

\title{
إع داء
}

د دمعد عبدالعزيز سليمان التمبيمي

قسم المناهج وطرق التدريس- كلية التربية- جامعة حئية حائل المملكة العربية السعودية البة التربية

DOI: 10.12816/EDUSOHAG. 2020.

المجلة التزبوية ـ العدد الخامس و السبعون - يوليو 2020م

Print:(ISSN 1687-2649) Online:(ISSN 2536-9091)

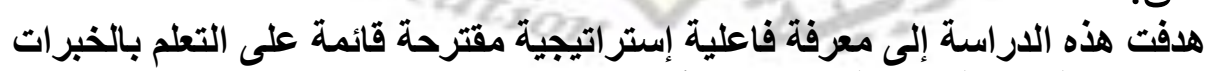

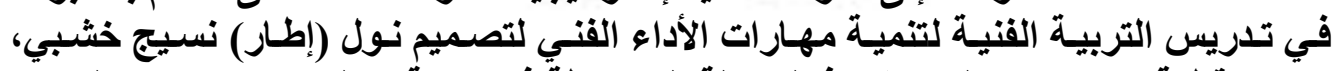

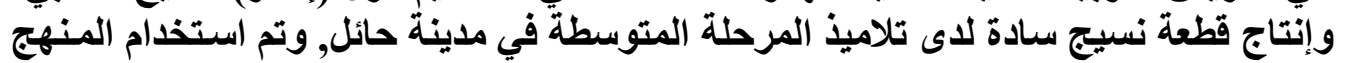

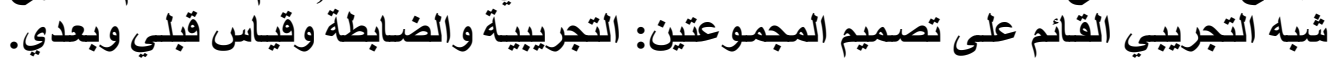




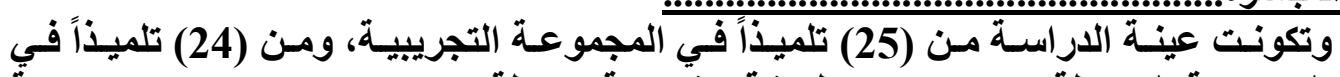

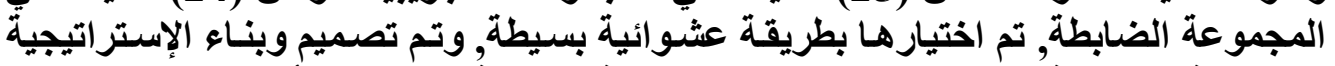

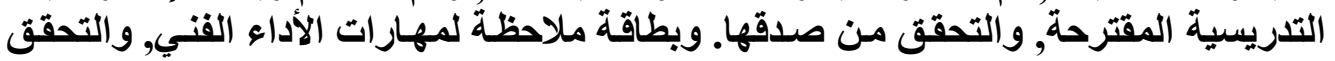

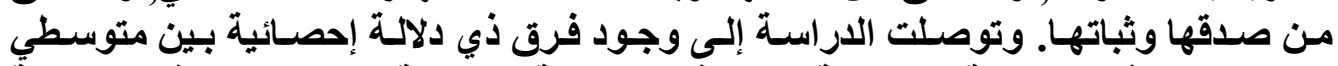

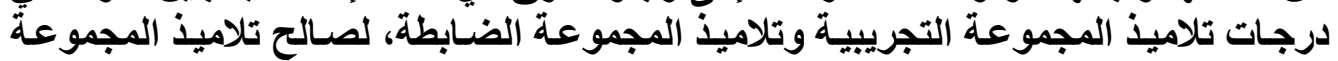

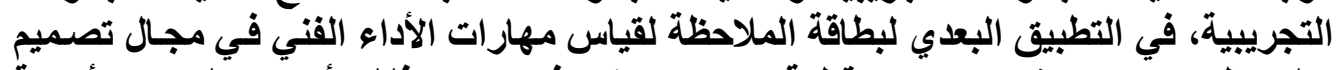

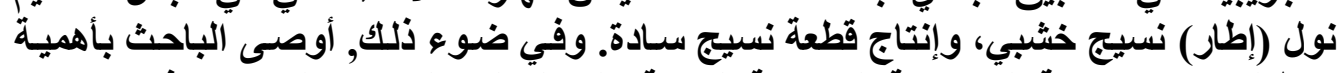

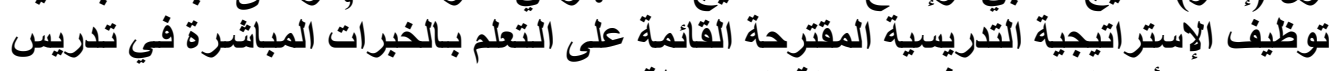

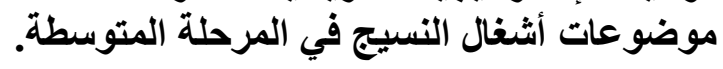
الكلمات المفتاحية: إستراتيجية تلديسية، التعلم بالخبرات المباشرة، مهارات الأداء القني. 


\title{
The Effectiveness of a Proposed Teaching Strategy Based on
} Learning with Direct Experiences in Teaching Art Education to Developing Technical Performance Skills for middle school students

\author{
Mohammad Abdulaziz Altamimi \\ Department of Curriculum and Instruction \\ , Faculty of Education, University of Ha'il
}

\begin{abstract}
:
This study aimed to identify the effectiveness of a proposed teaching strategy based on learning with direct experiences in developing technical performance skills among third-grade students in Hail. The quasi-experimental approach, based on the design of the two groups, was used: experimental and control; pre and post measurement. The sample of the study consisted of (25) students in the experimental group, and (24) students in the control group; chosen in a simple random manner. The proposed teaching strategy was designed, built, and validated. An observation checklist was used for technical performance skills; it was made valid and reliable. The study found out that there is a statistically significant difference between the mean scores of the experimental group students and the control group students, in favor of the experimental group students, in the post application of the observation checklist to measure the technical performance skills. In the light of this, the researcher recommended the importance of employing the proposed teaching strategy based on learning with direct experiences in teaching technical works topics at the intermediate stage.
\end{abstract}

Key words: teaching strategy, learning with first-hand experience, technical performance skills. 


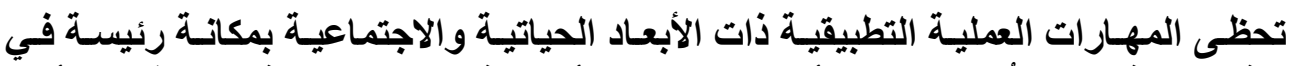

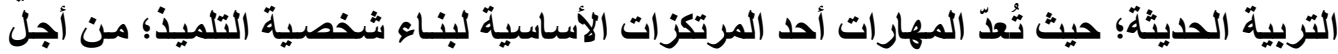

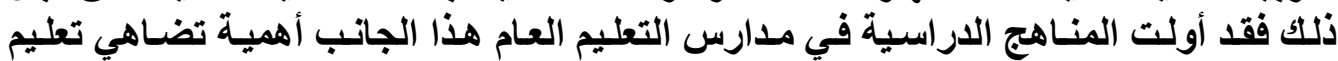

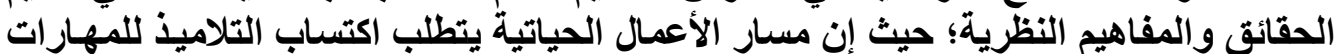

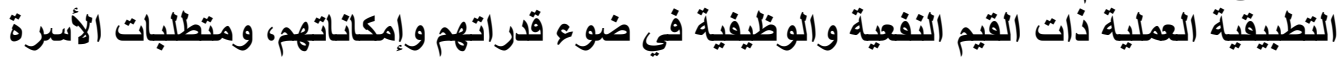

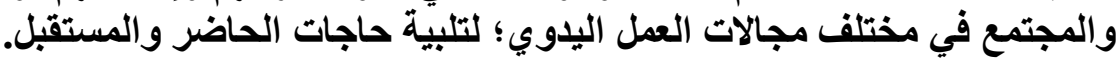

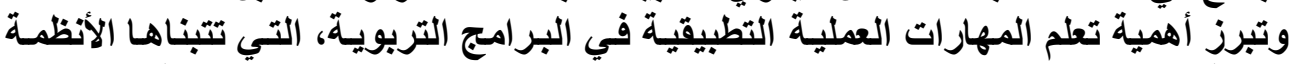

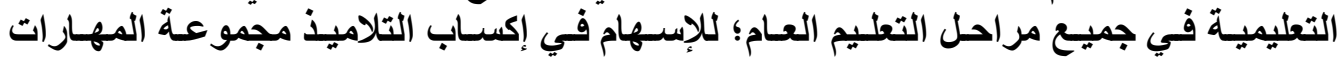

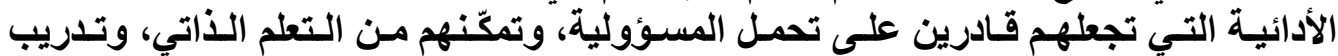

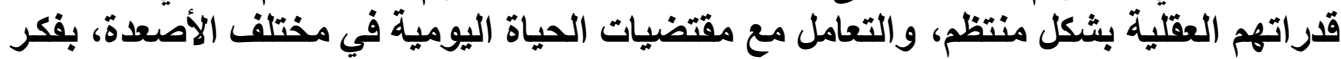

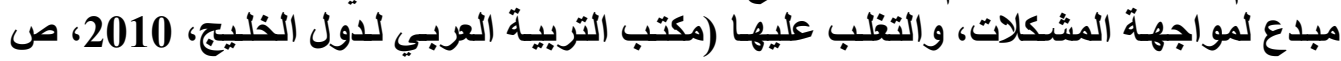

وقد نادى المربي الأمريكي جون ديوي John Dewey في باية القرن العشرين لاستخدام

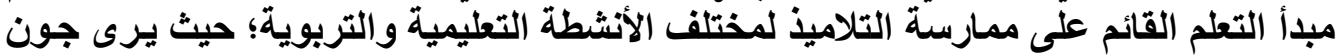

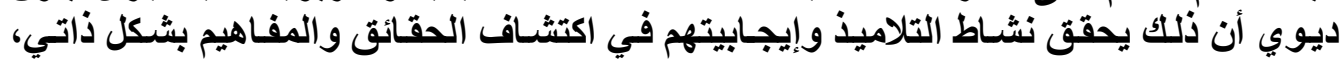

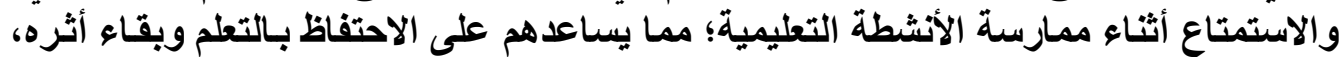

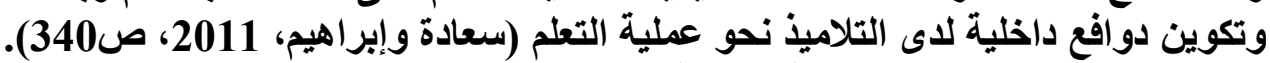

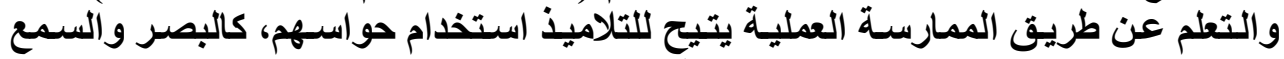

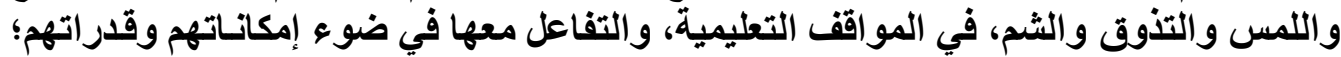

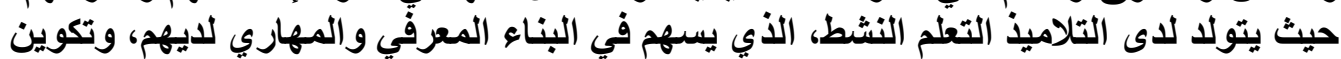

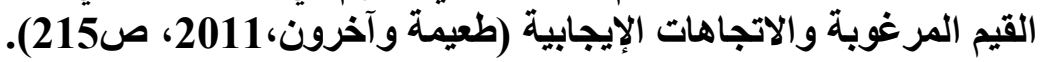




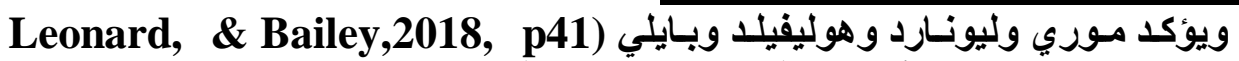
(Moore, Holifield

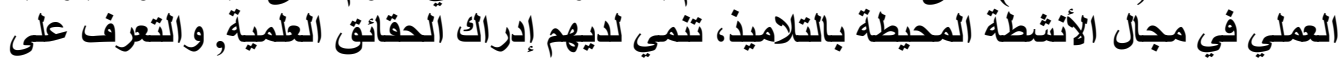

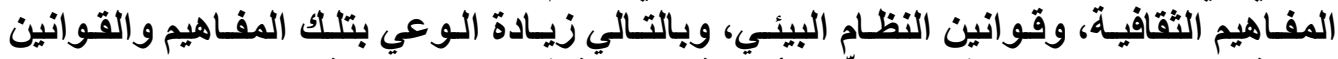

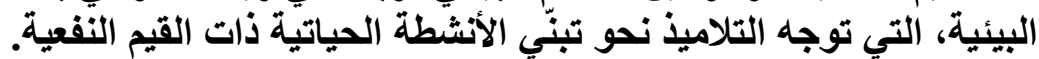

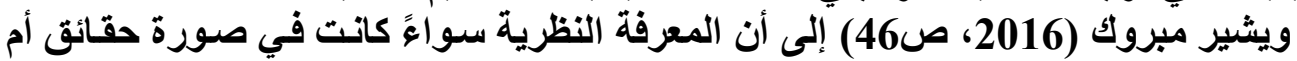

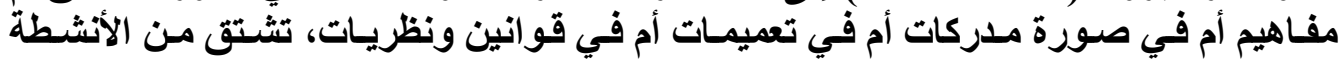

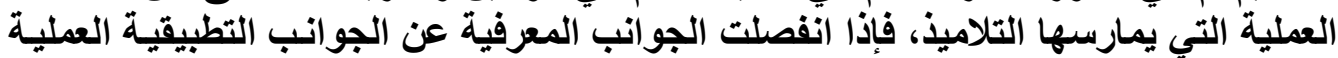

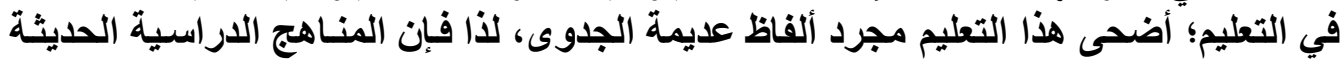

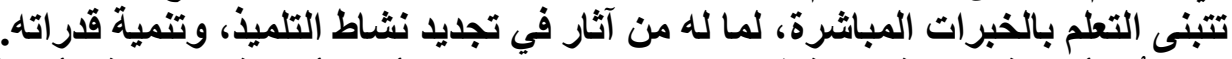

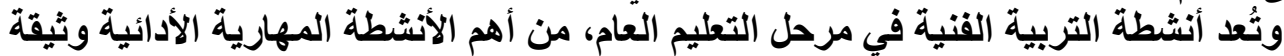

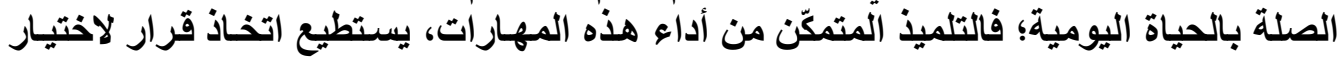

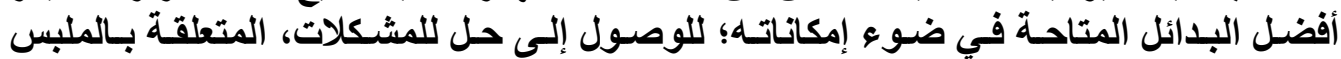

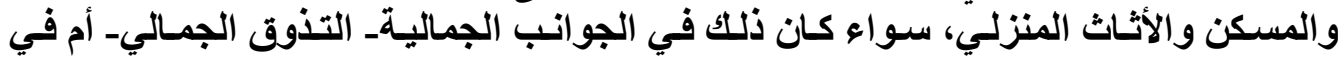

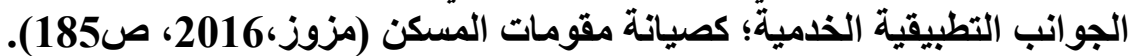

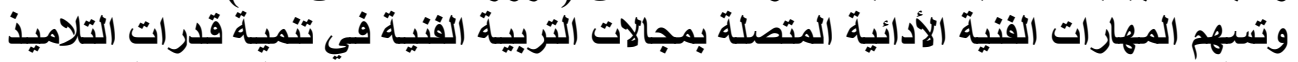

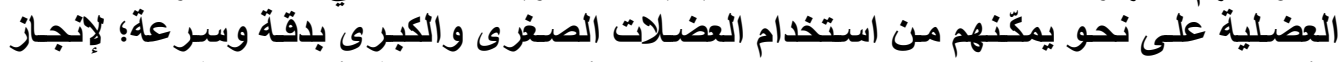

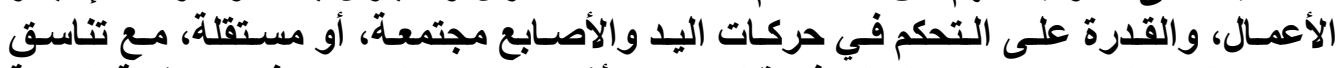

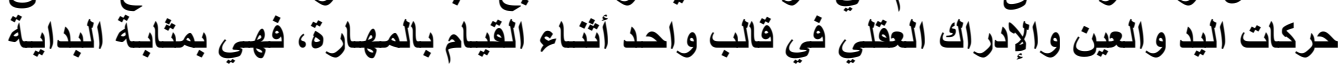

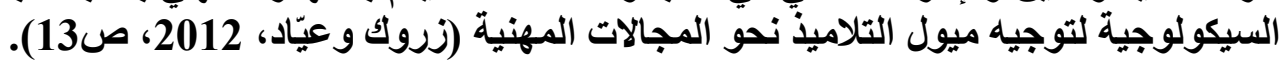

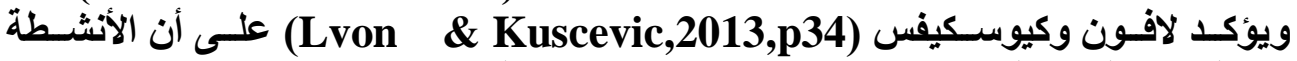

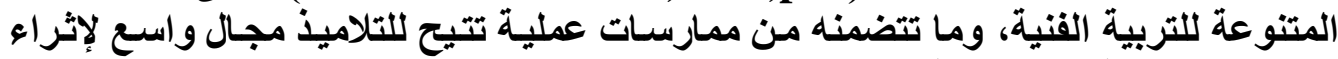

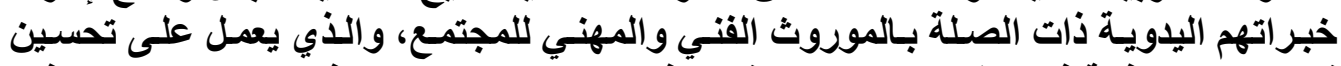

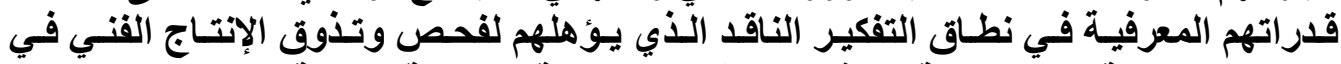

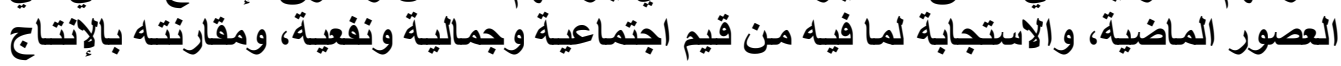

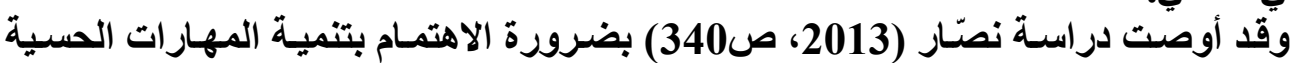

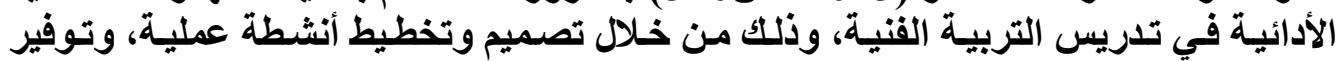

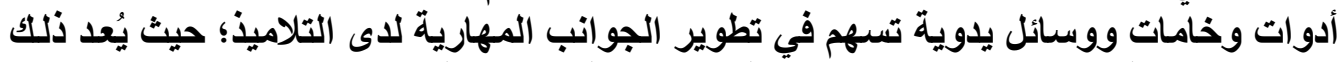

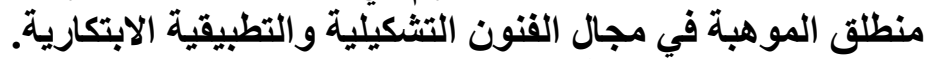

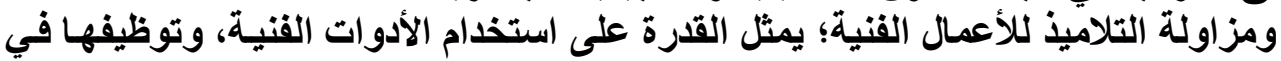

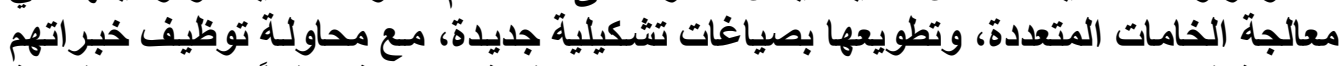

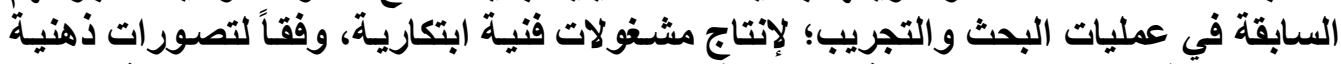

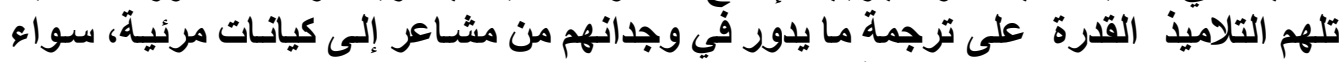

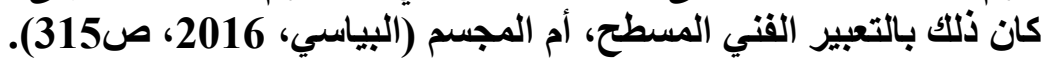

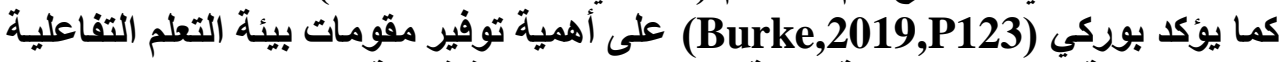

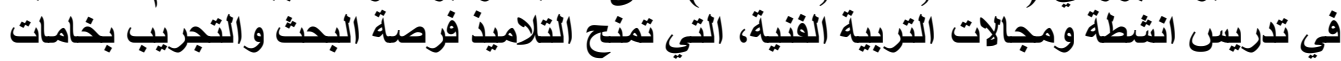

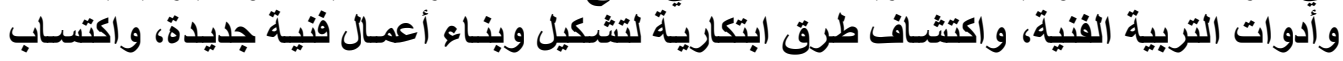




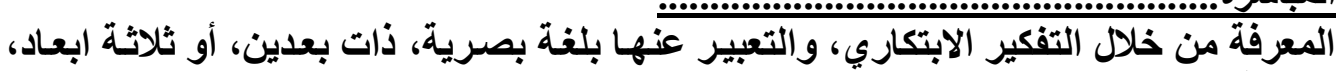

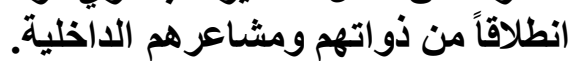
وقد أشـارت دراسـة هورسن وآيسيلك (Hursen \& Islek,2017,P13) إلى أن بيأنسة

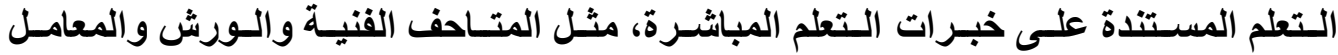

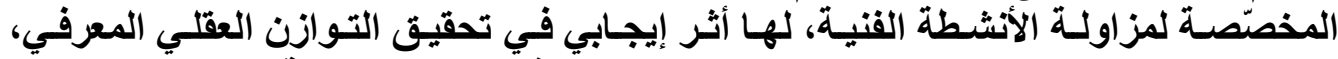

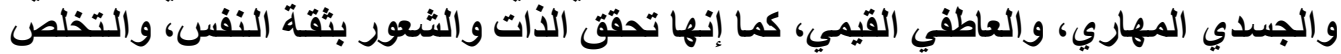

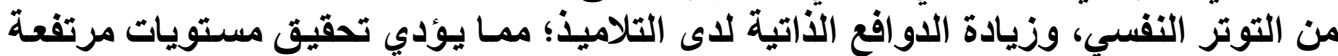

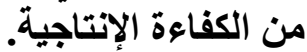

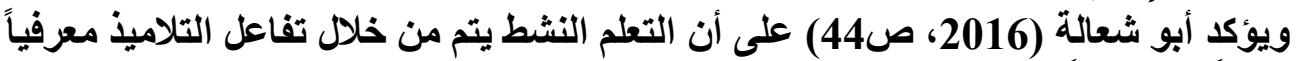

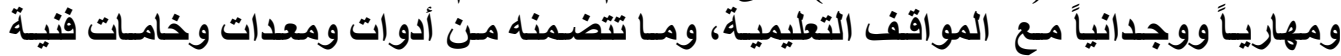

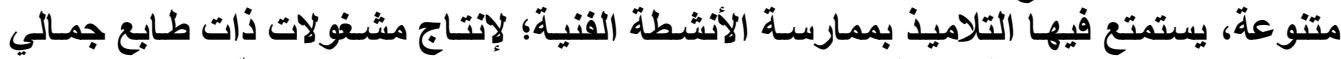

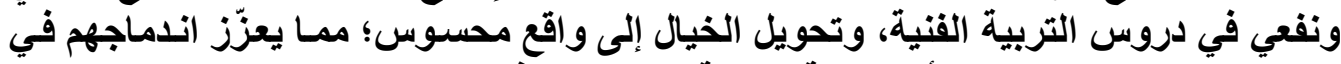

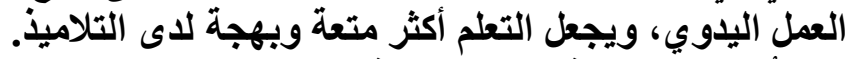

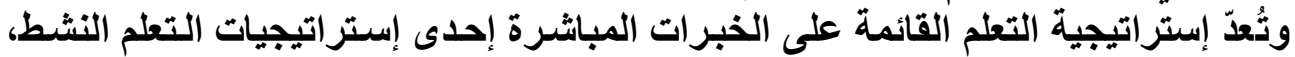

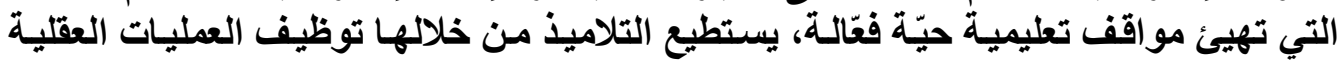

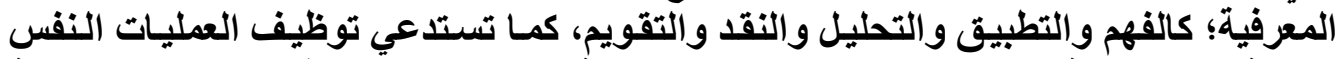

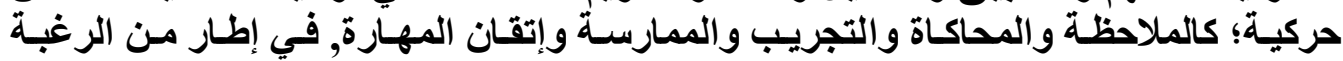

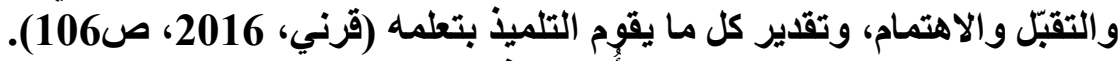

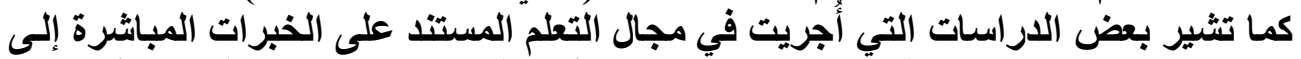

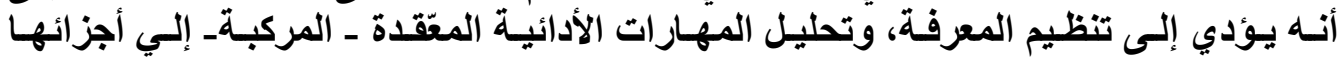

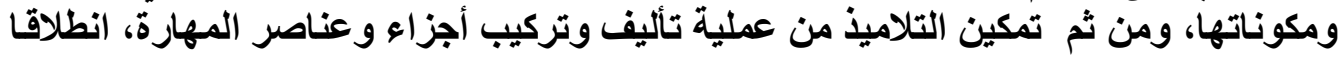

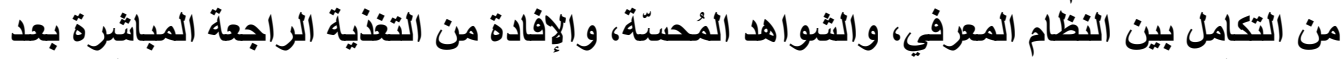

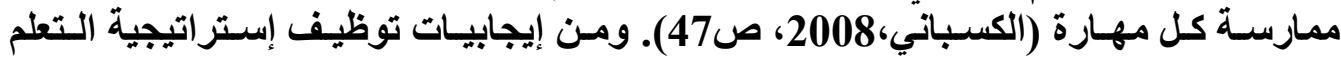

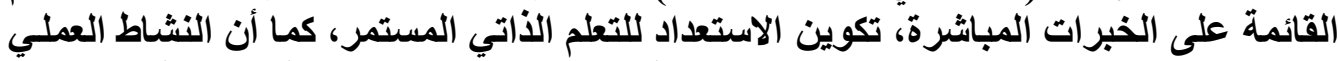

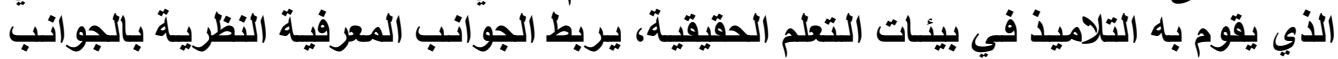

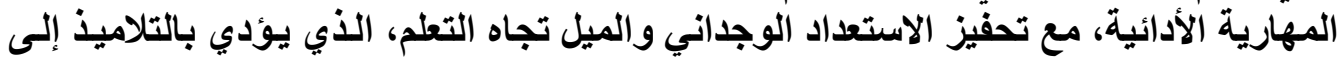

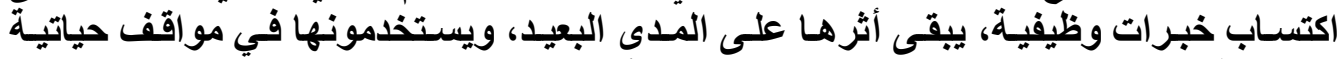

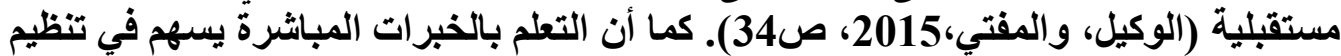

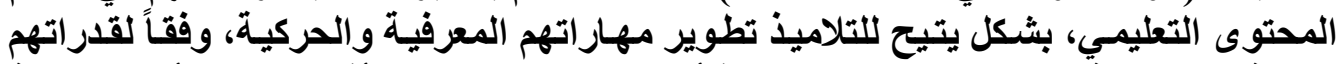

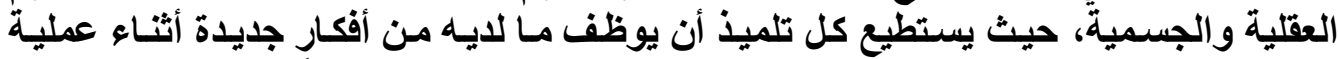

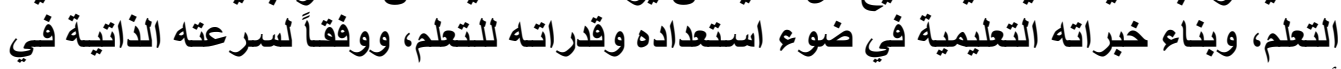

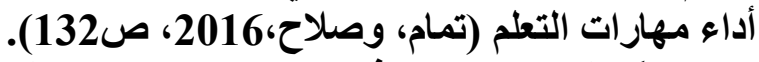

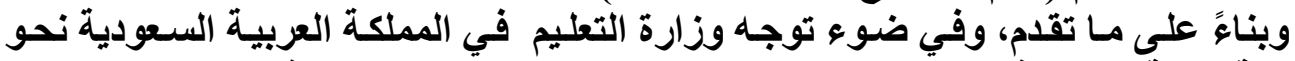

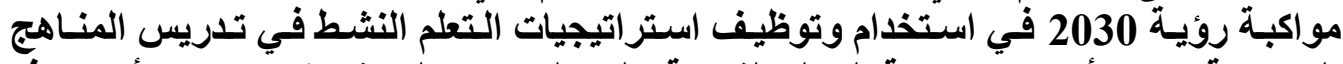

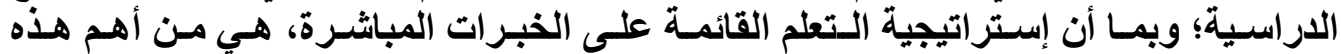

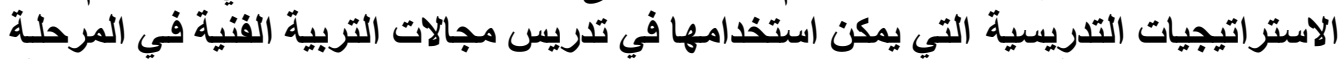

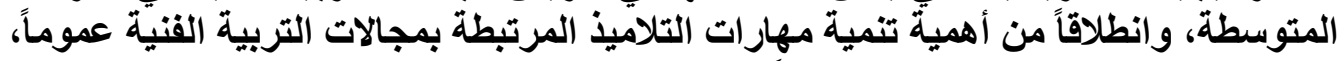

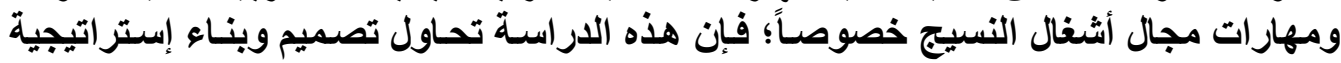




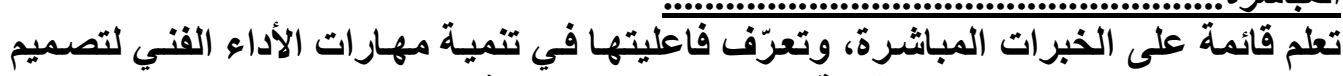

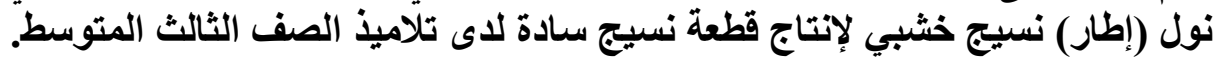

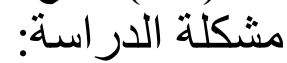

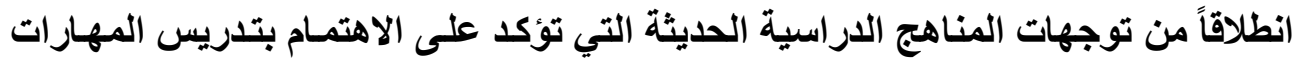

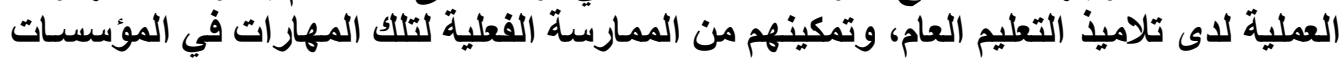

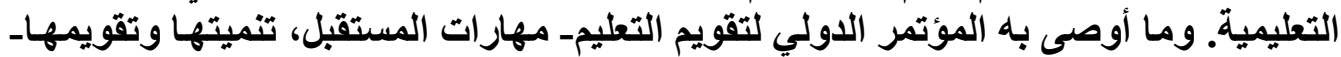

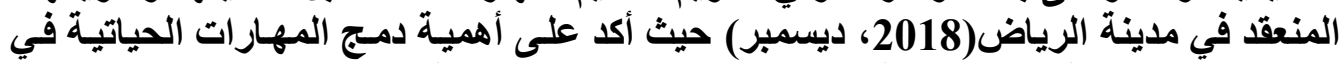

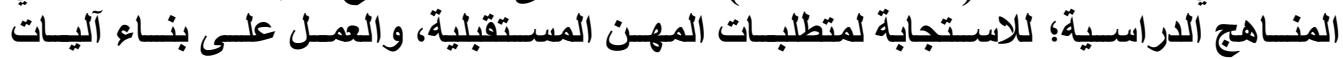

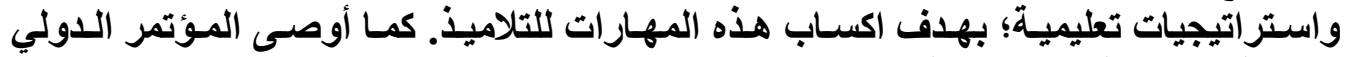

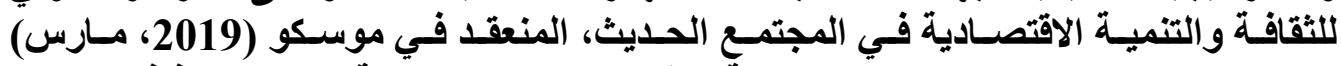

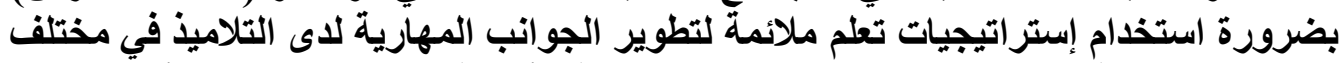

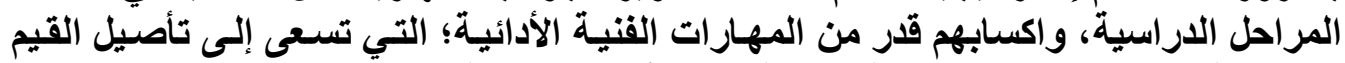

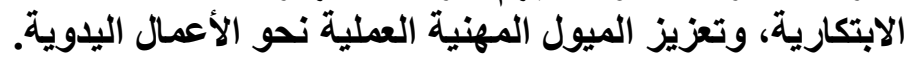

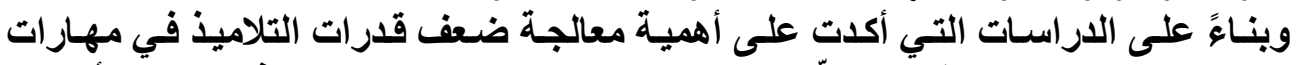

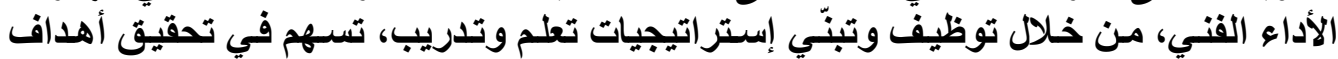

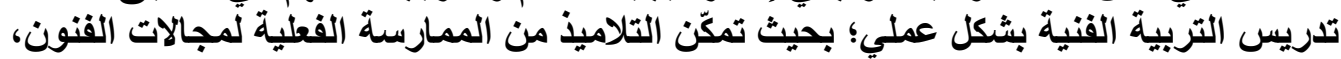

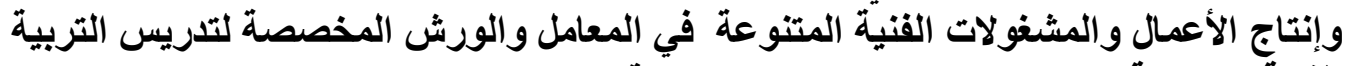

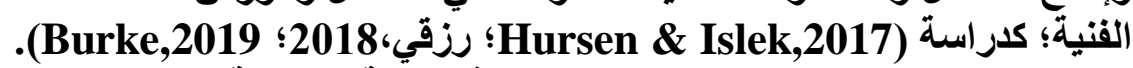

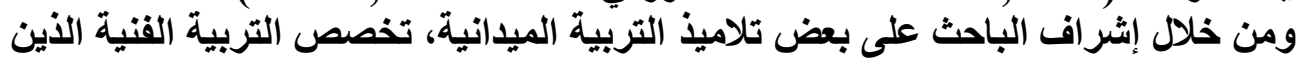

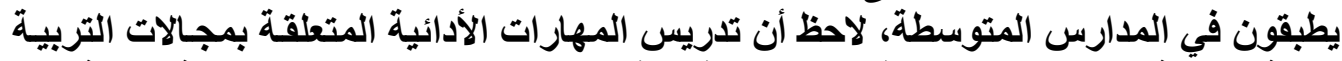

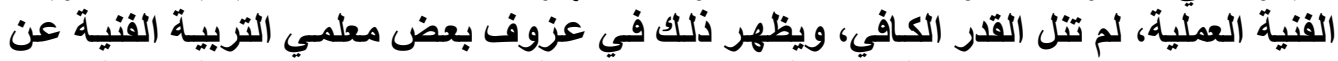

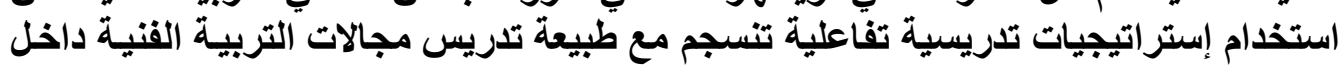

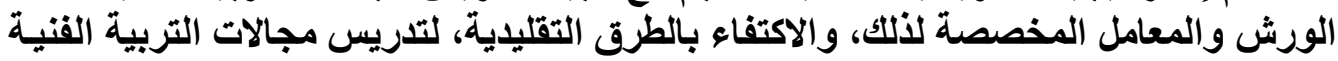

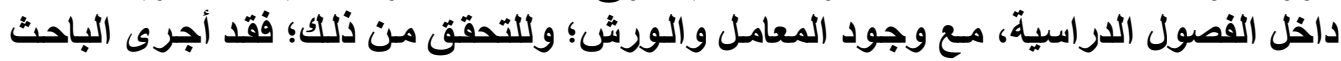

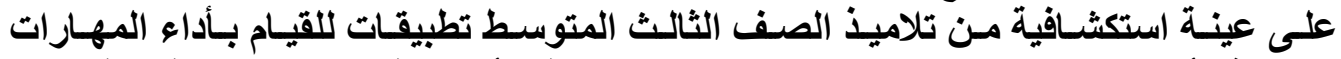

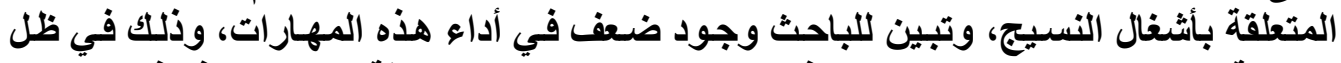

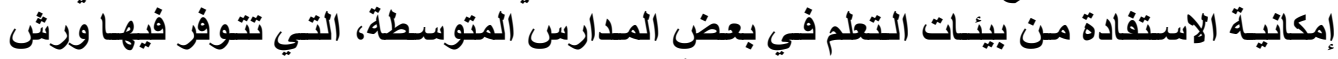

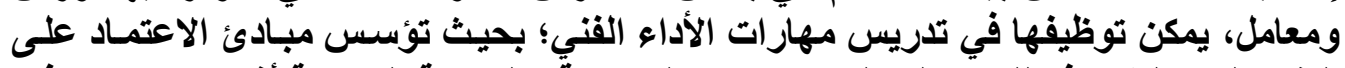

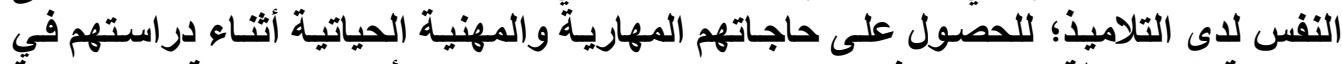

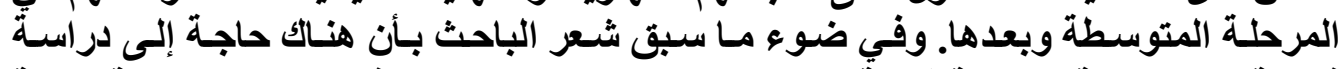

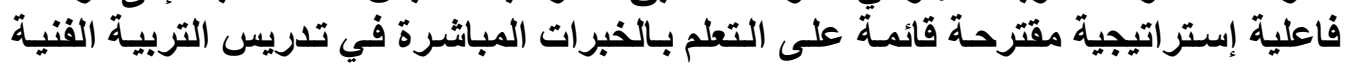

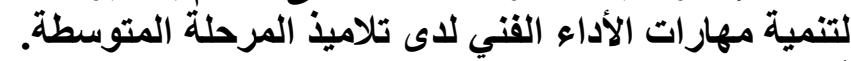

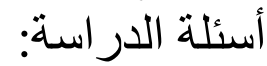

في ضوء مشكلة الاراسة؛ فقد جاءت للإجابة عن السؤال الرئيس الآتي:

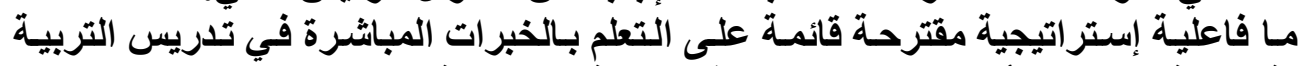

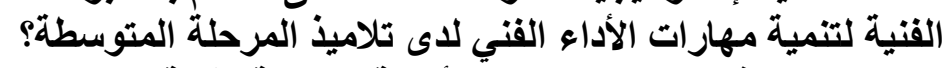
ويتفرع من هذا السؤال الرئيس، الأسئلة الفرعية الآتية: 


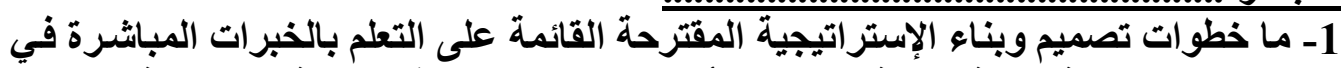

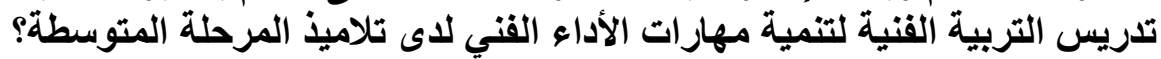

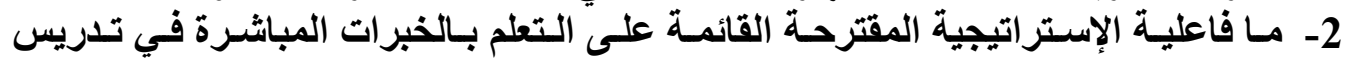

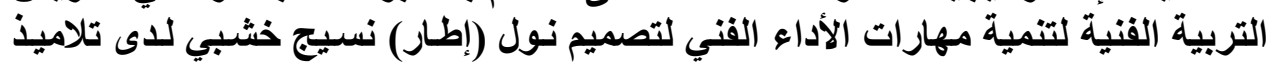

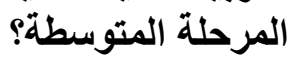

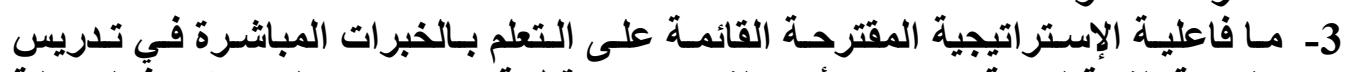

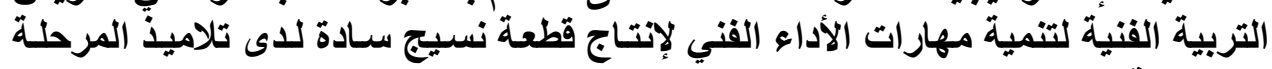

$$
\text { أهداف الدتوسطة؛ التة }
$$

تهـف الاراسـة الحالية إلى الى تصميم وينـاء إستراتيجية مقترحة قائمسة على التعلم بـالخبرات

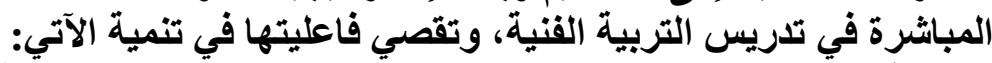

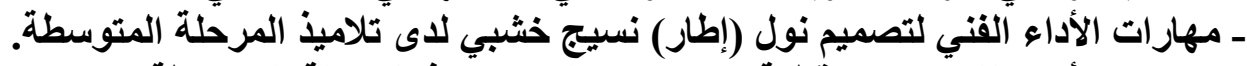

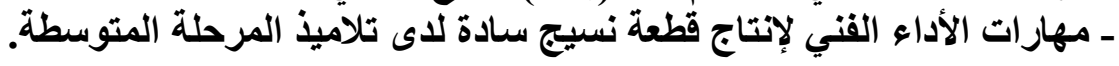




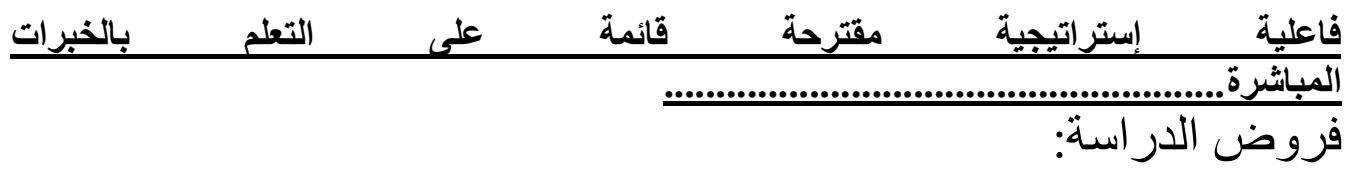

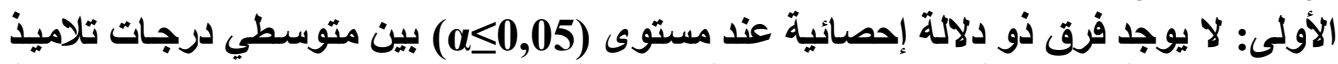

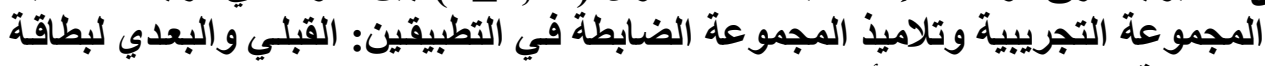

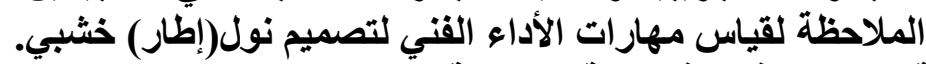

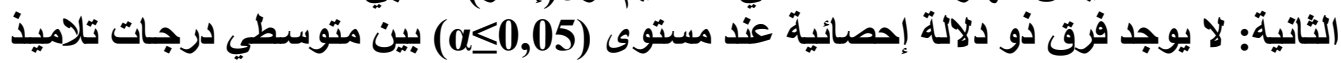

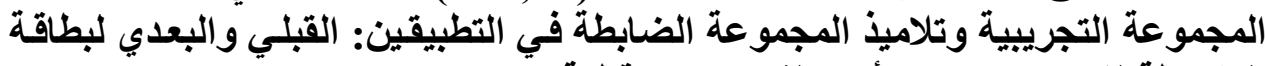

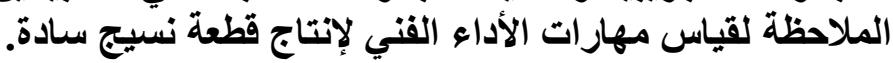

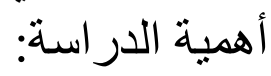
تكمن أهية الاراسة في الجواتب الآتية:

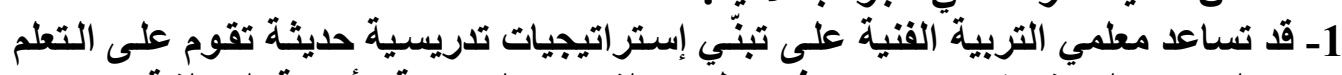

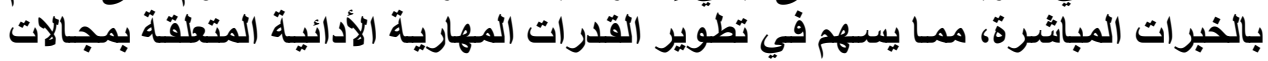
التربية القنية لاى التباتلاميذ.

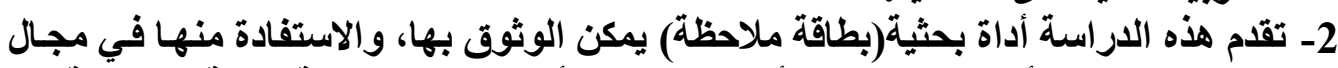

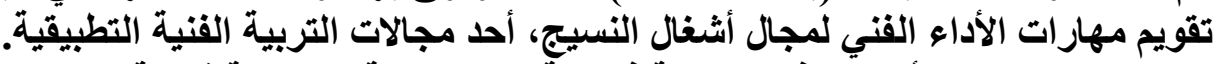

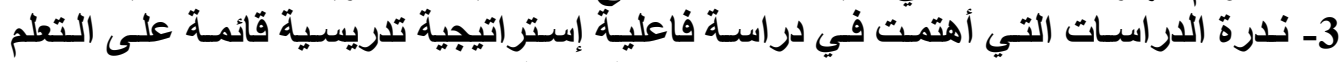

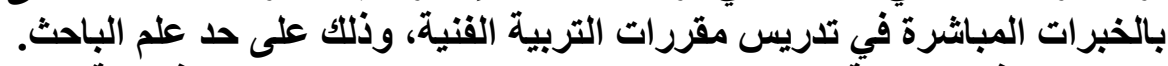

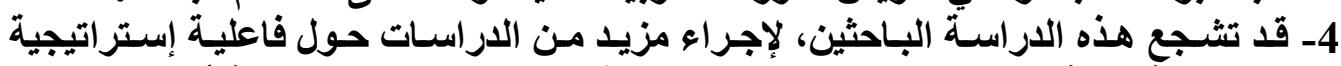

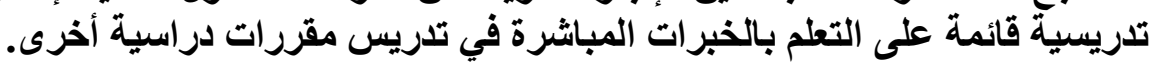




على

عرّف شحاتة وزينب النجار (2011، صأ230) الفاعلية بأنها مدى حجم التغيير الذي يمكن

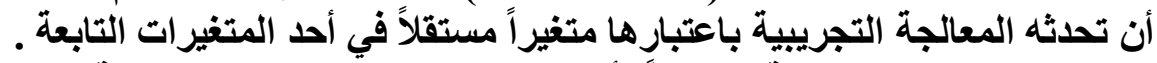

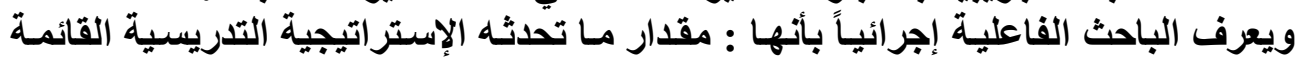

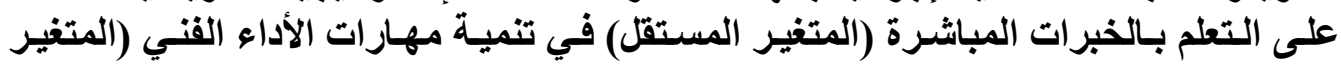
التابع).

الإستر اتيجية القائمة على التعلم بالخبر ات المباشرة:

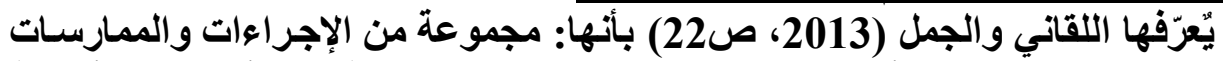

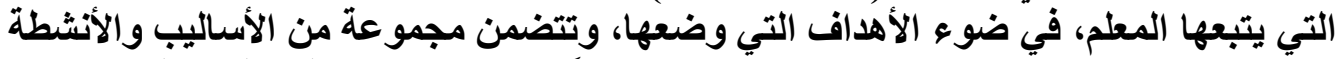

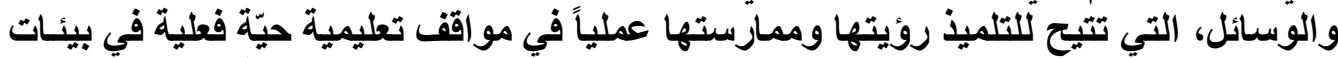

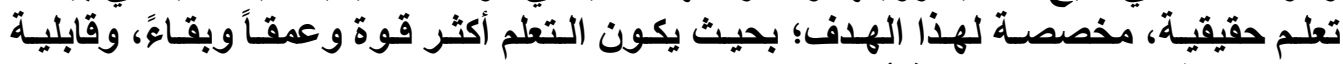

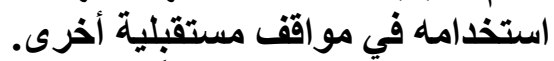

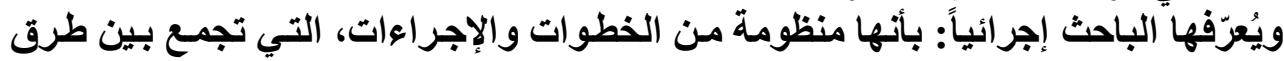

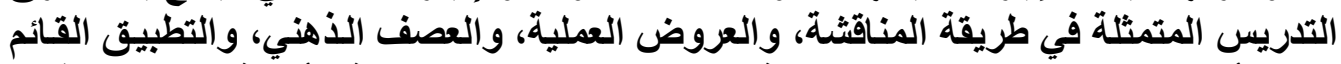

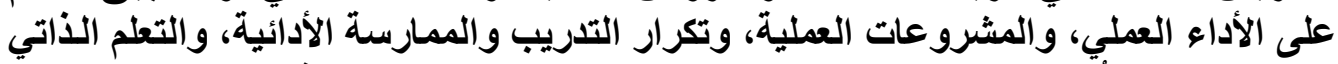

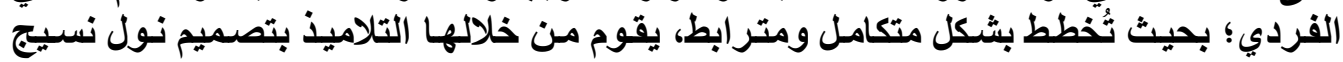

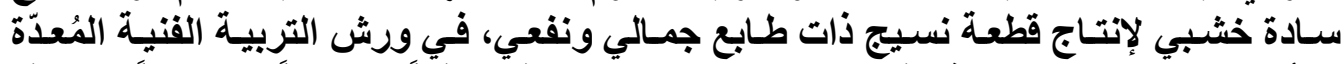

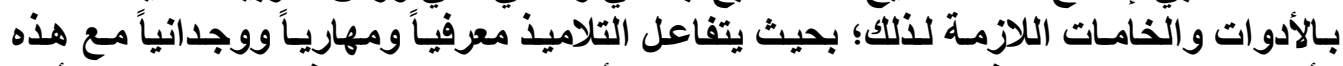

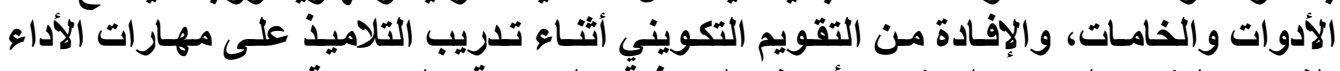

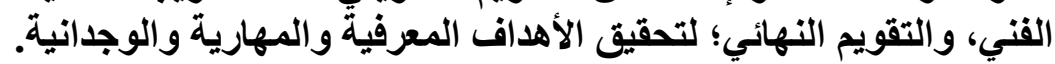
التربية الفنية:

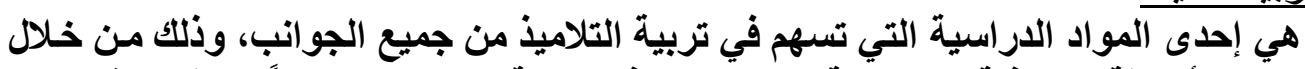

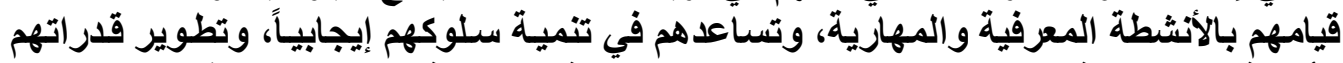

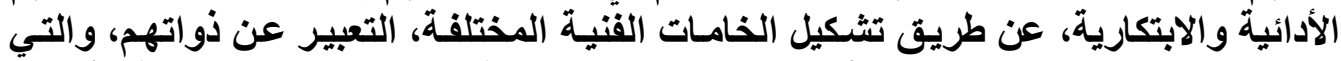

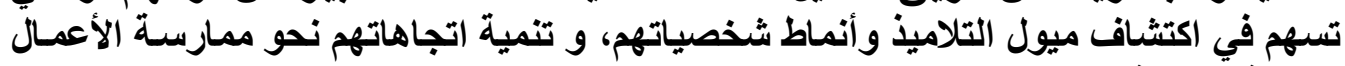

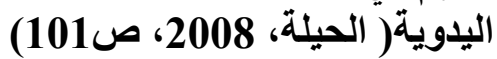
ويرى الباحث أن هذا التعريف هو الأنسب إجرائياً.

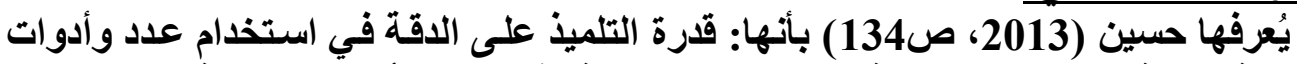

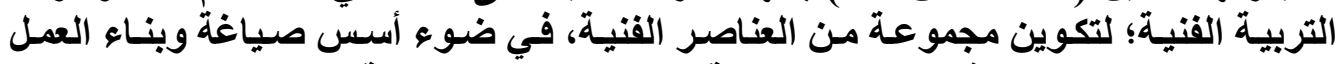

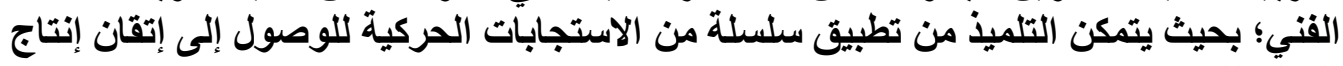

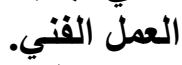

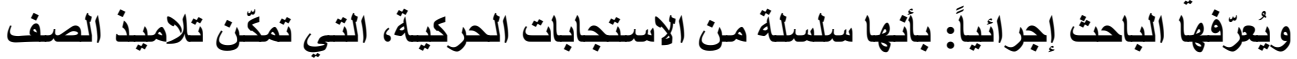

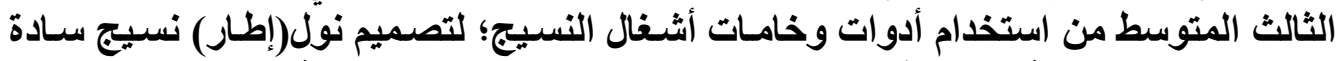

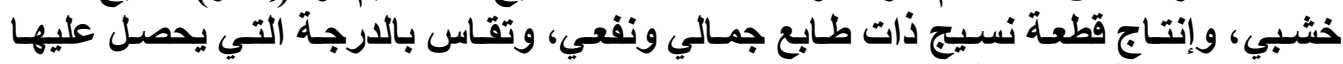

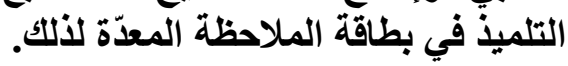




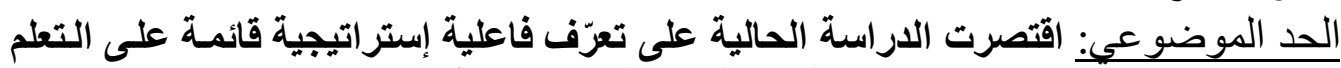

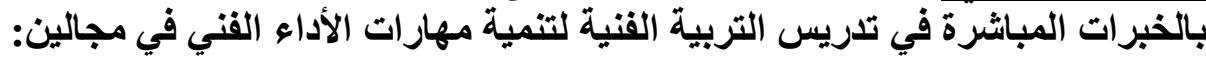

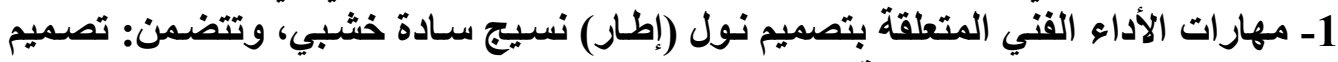

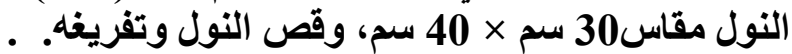

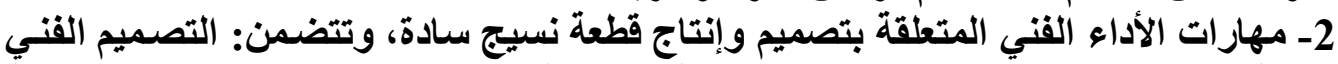

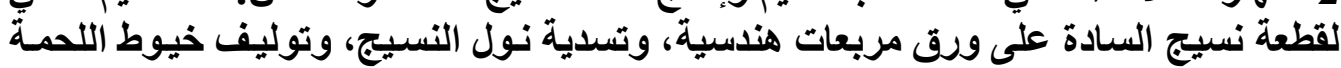
لإنتاج قطعة نسيج السادة.

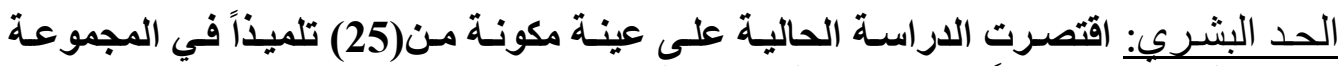
التجريبية، و(24) تلميذاً في المجموعة الضابطة، من تلاميذ الصف الثالث المتوسطة الحد الزماني: تم تطبيق هذه الدراسة في الفصل الدراسي الثاني من عام 1440هـ/1441هــــ

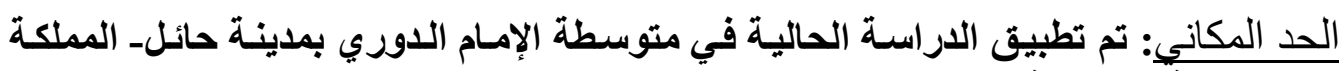
العربية السعودية. تمبية.

الإطار النظري للار اسة: تصميم وبناء الإستر اتيجية المقترحة القائمة على

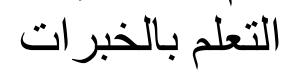

\section{المباشرة في تدريس التربية الفنية:}

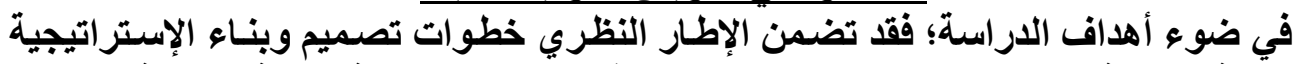

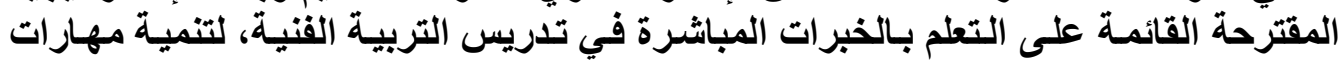

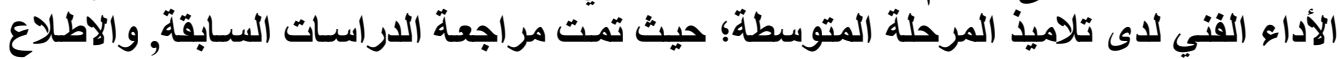

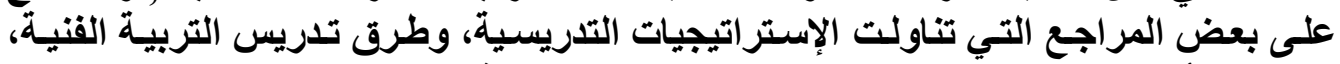

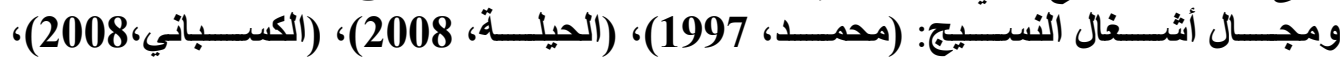

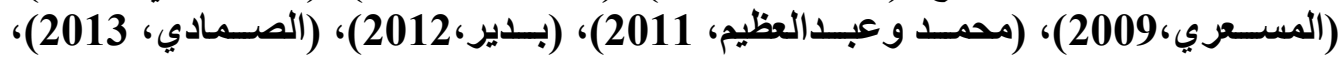

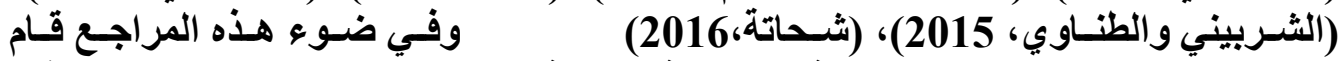

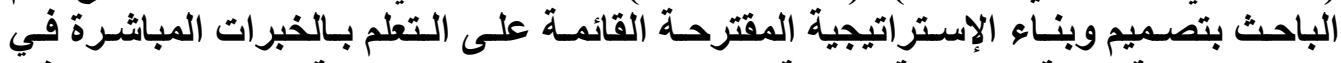

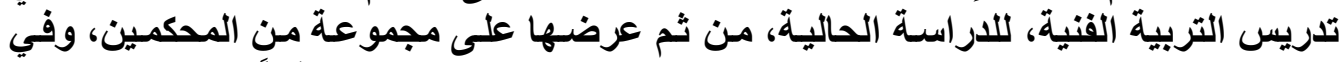

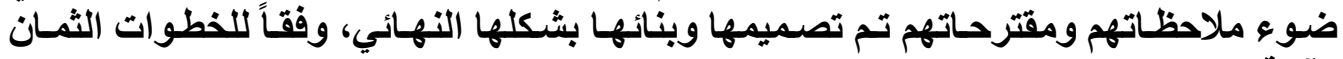

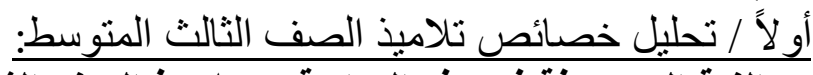

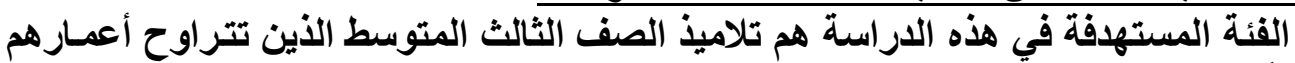

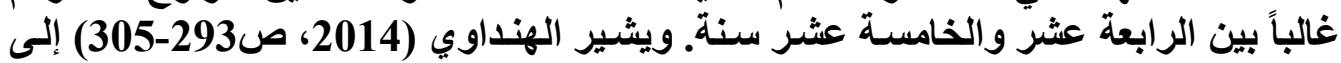

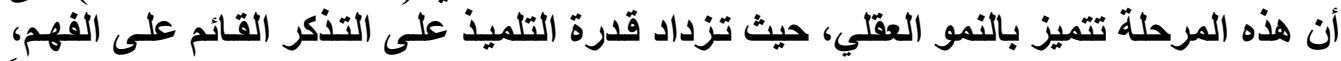

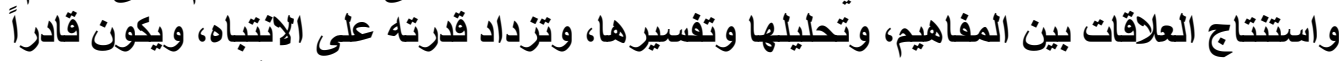

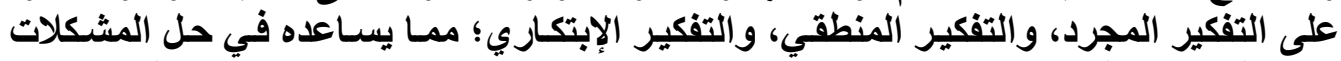

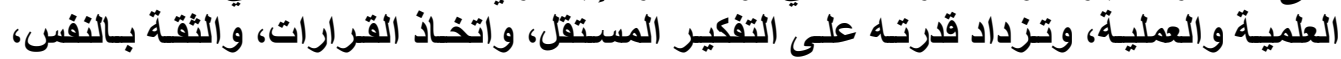

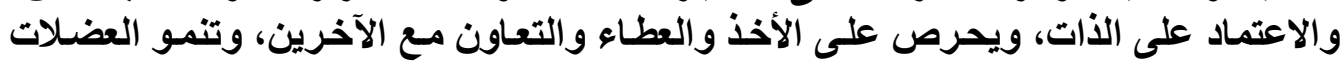




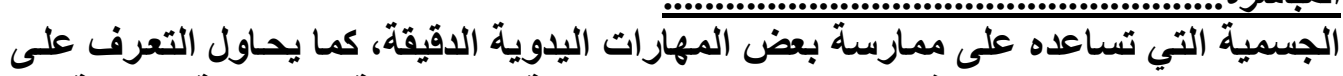

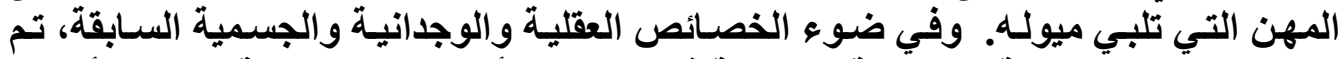
تحديد الخبرات التعليمية والتربوية، المتمثلة في مهارات الأداء الفني المتصلة بدروس أشئلة الثغال

ثانياً / تحديد الحاجات التعليمية و التربوية لتلاميذ الصف الثالث المتوسط:

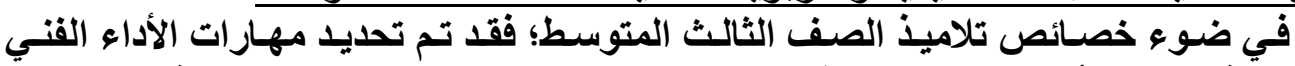

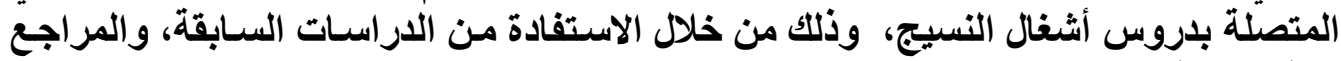

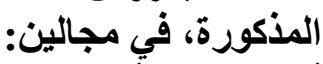
أـ مهارات الأَداء الفني المتعلقة بتصميم نول (إطار) النسيج الخشبي.

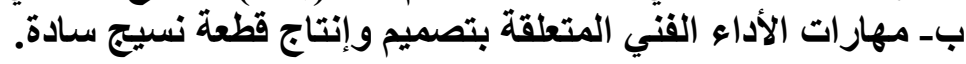

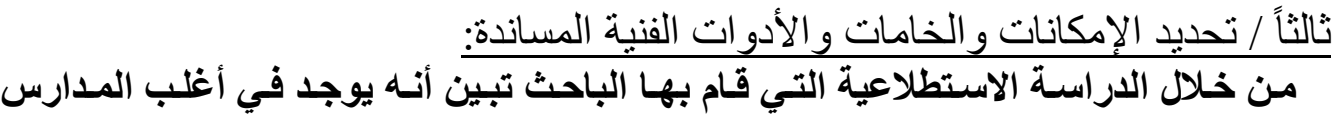

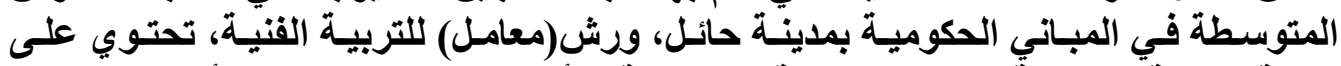

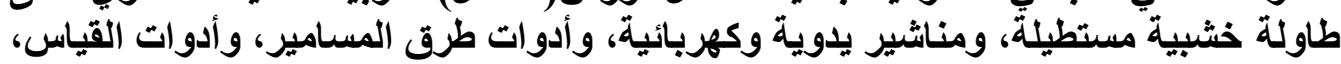

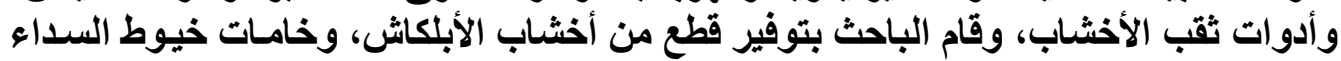

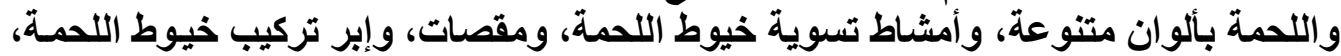

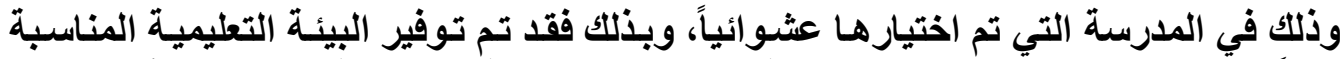

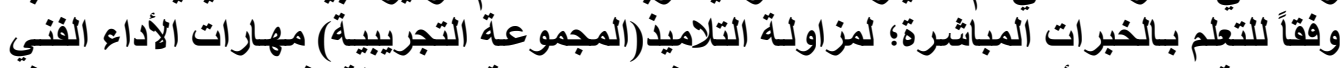

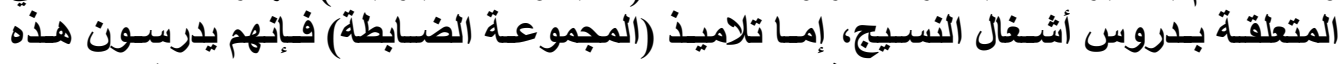

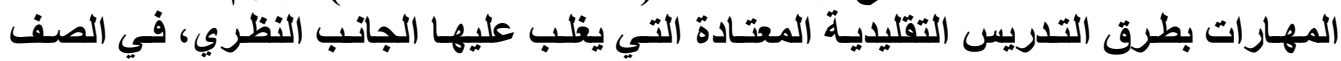

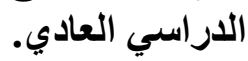
رِ رابعاً / تحديد الهدف العام للإسـتر اتيجية المقترحة القائهـة على التعلم بـالخبر ات المباثـرة

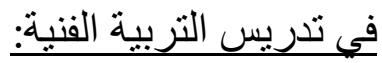

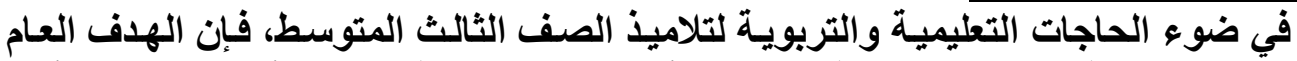

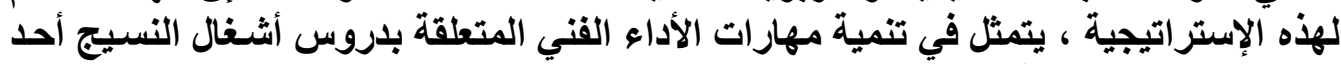

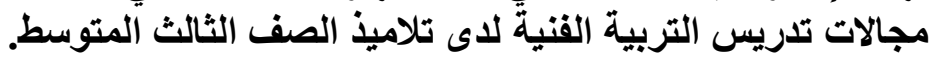




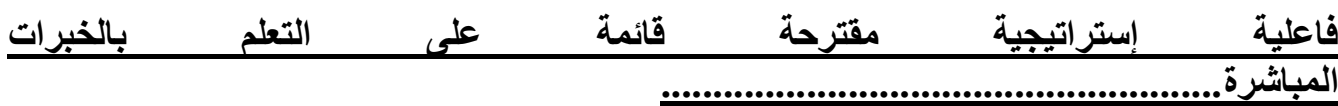

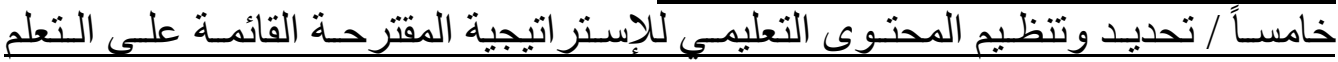

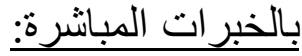

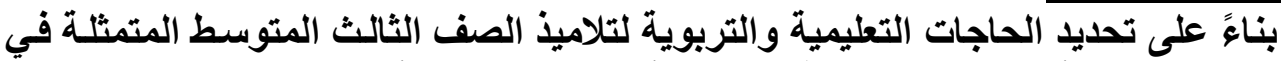

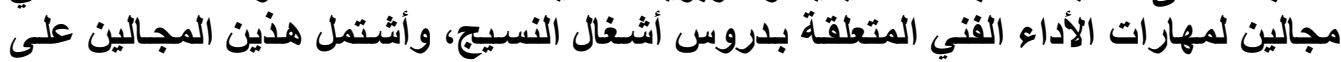

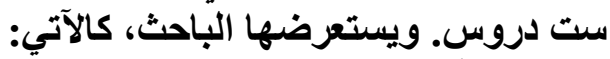

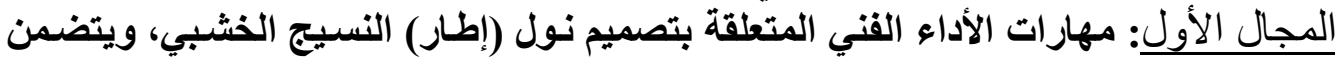

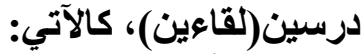

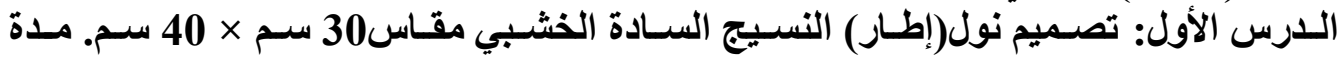

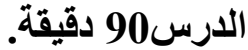
الأهداف التعليمية الإجرائية للارس الأولة الأول: ـ أن يفرّق التلميذ بين وحدات القياس الكبيرة ووحدات القياس الصغيرة المستخدمة في تصميم نول النسيج السادة. ـ أن يحدّد التلميذ أطوال مقاس النول النول 30 سم×40 سم على قطعة خثب أبلكاش ملائمة.

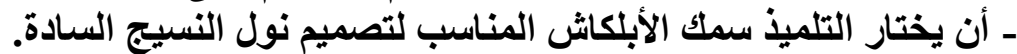

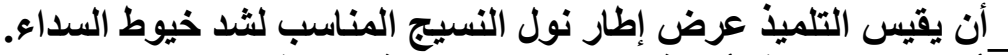

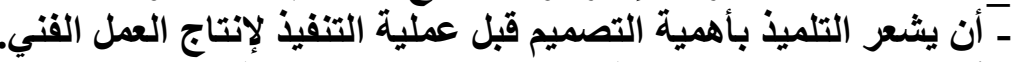
ـ أن يقّر التلميذ فوائد خامة الخشب فئمئ فئ الحياة اليومية.

الارس الثاني: قص وتفريغ نول(إطار) النسيج الخثبي. مدة الدرس 90 دقيقة.

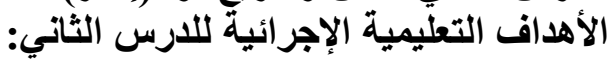

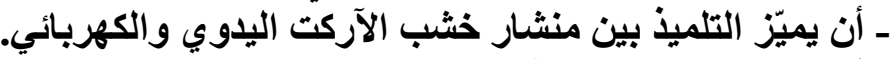

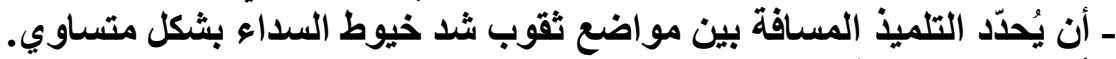

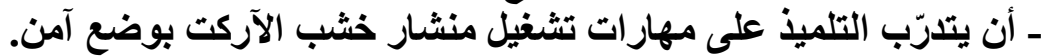

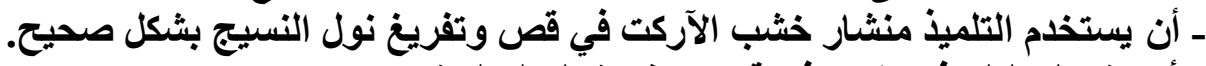

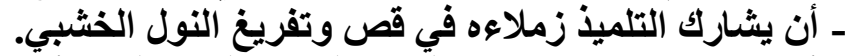

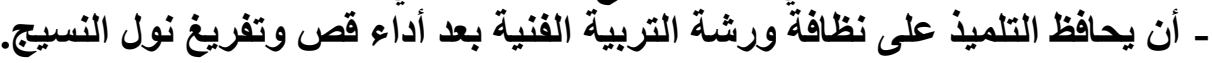

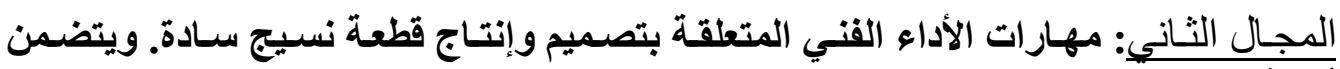

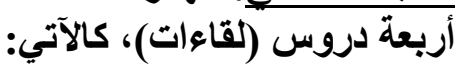
الارس الثالث: التصميم الفني لقطعة نسيج السادة على ورق مربعات هندسية. مدة الدرس90

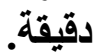
الأهداف التعليمية الإجرائية للارس الثالث: ـ أن يميّز التلميذ بين ألتئ أوراق المربعـات الهندسية المناسبة لتصميم وحدات زخرفية لتكوين وإنتاج قطعة نسيج أنس السادة. ـ أن يعدّد التلميذ عناصر تصميم وحدات زخرفية هندسية لتكوين وإنتاج قطعة نسيج السادة.

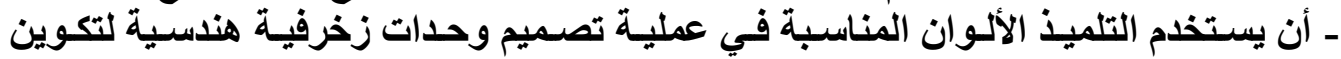
وإنتاج قطعة نسيج السادة. ـ أن يصمّم التلميذّ وحدات زخرفية هندسية على ورق المربعات في ضوء عدد خيوط السداء. 


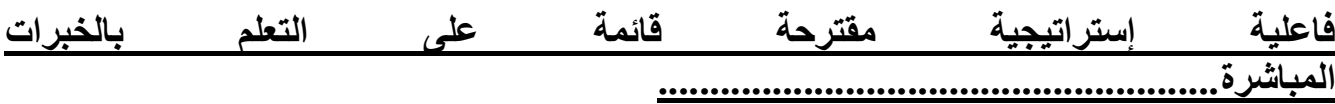

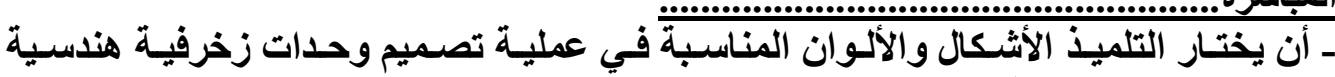
لتكوين وإنتاج قطعة نسيج السادة الناد. ـ أن يقدرّ التلميذ أراء زمـلاءه في تولئ فيد أفكار ابتكاريـة ملائمسة في تصميم وحدات زخرفيـة

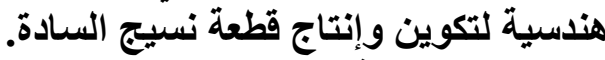

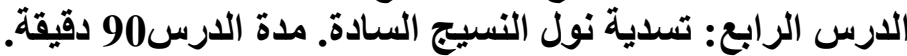

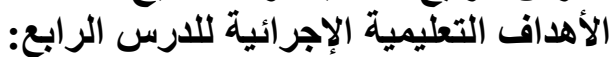

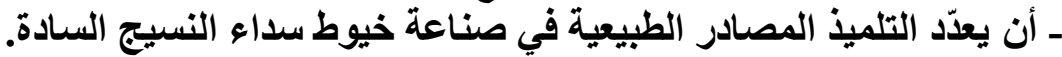

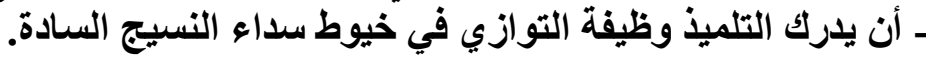
ـ أن يستخدم التلميذ المثاقب المخصّّة في في النول الخشبي لتركيب خيوط سداء النسيج بطريقة

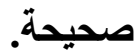
ـ أن يشُدّ التلميذ خيوط سداء النسيج بتوازي ويشكل صحيح.

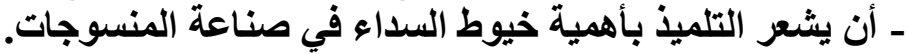

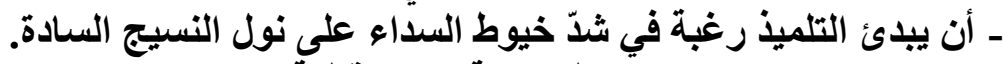

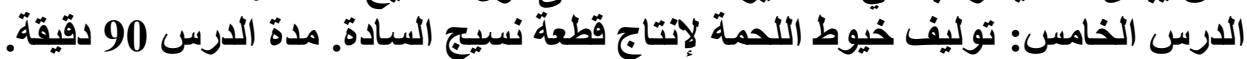
الأهداف التعليمية الإجرائية للارس التوس الخامس: لإنتاج:

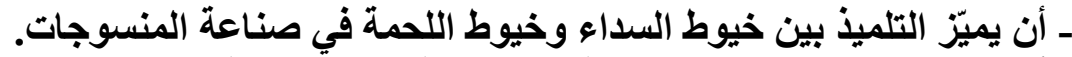

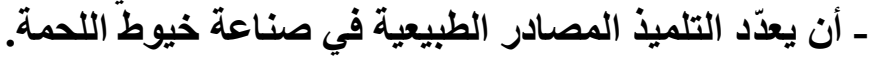

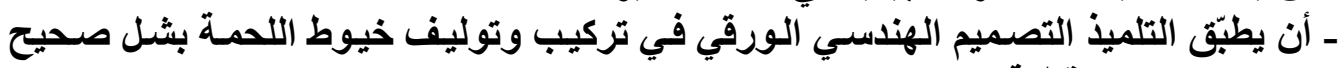

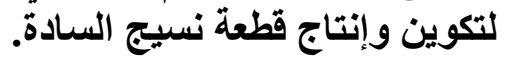
ـ أن يستخدم التلميذ الميير في تركيب وتئ فئليف خيوط اللحمة بثل صحيح لتكوين وإنتاج قطعة نسيج السنادة. ـ أن يثمّن التلميذ جهود الأجداد في صناعة المنسوجات بشكل جمالي ونفعي.

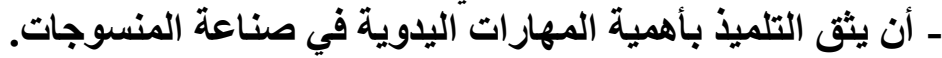

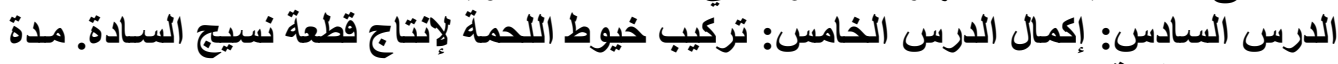
الارس 90 دقيقة. سالادساً تحديد طرق التدريس المستخدمة في الإستر اتيجية المقترحة القائمـة على التعلد

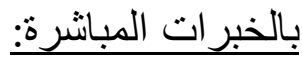

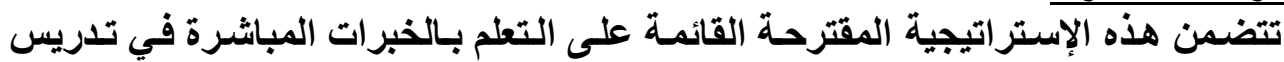

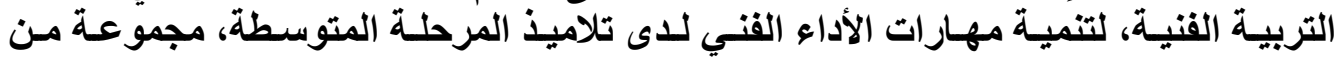

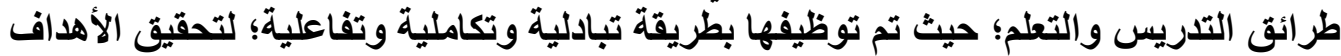

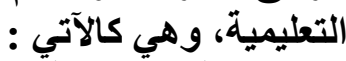

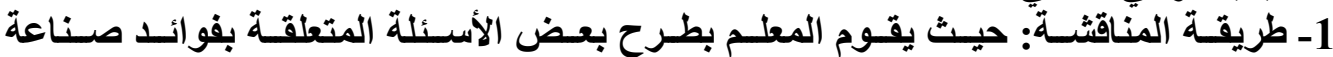

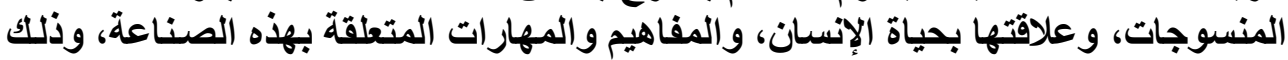

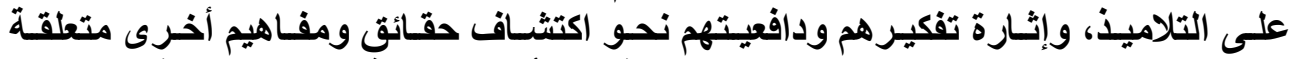

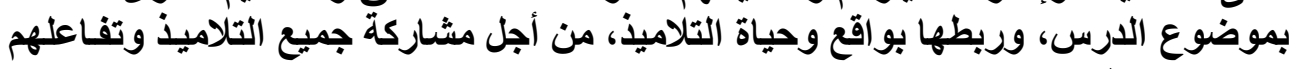
مع عناصر الارس. 


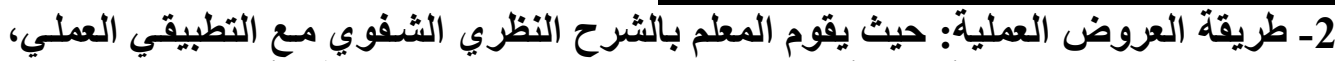

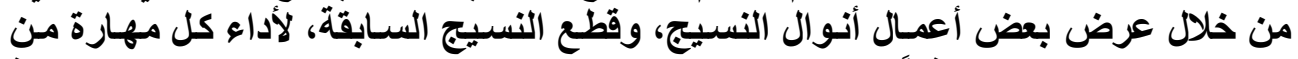

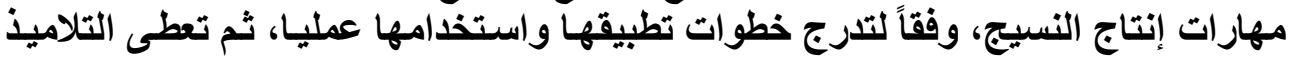

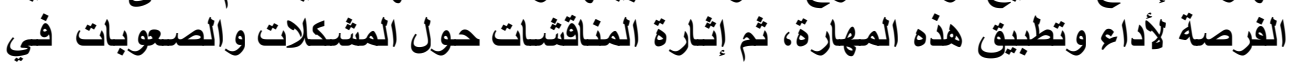
عمليات التطبيث.

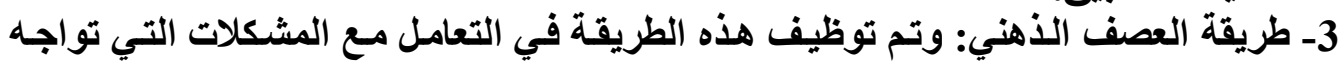

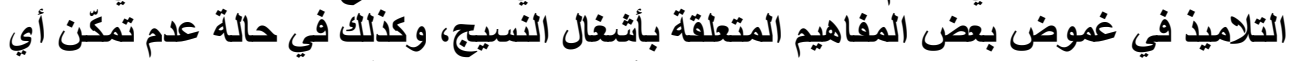

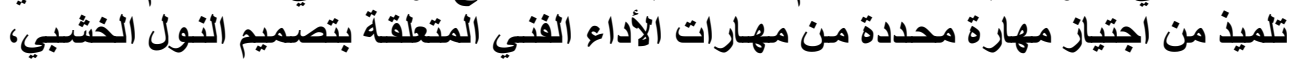

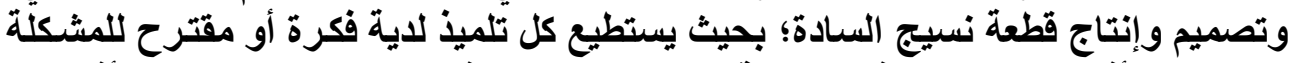

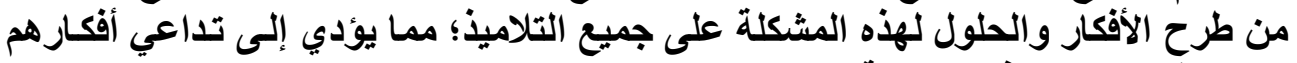
واستمطار ها لحل هذه المشكلة.

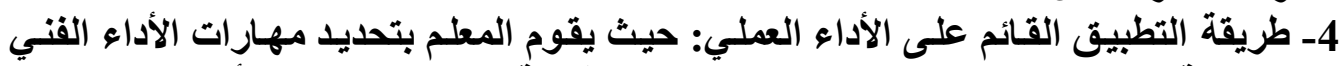

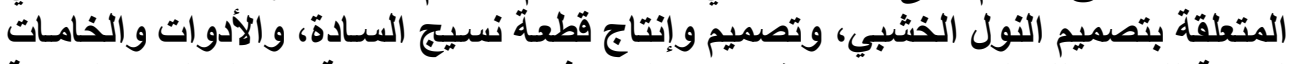

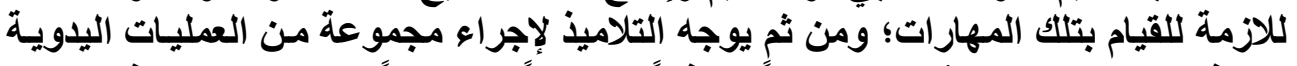

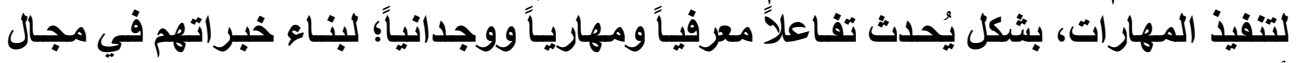

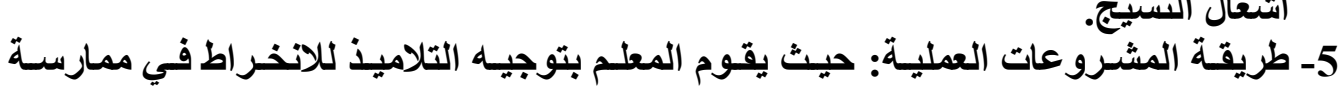

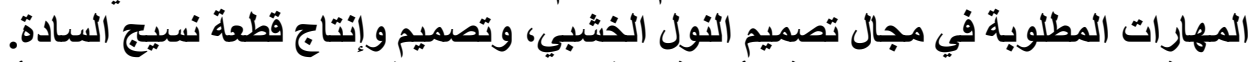

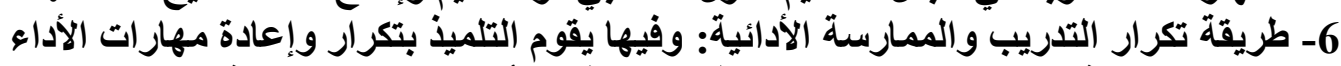

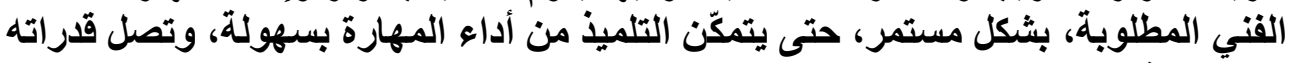

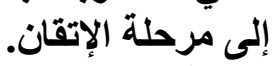

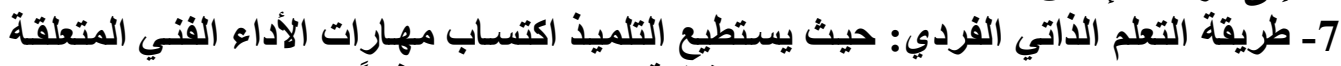

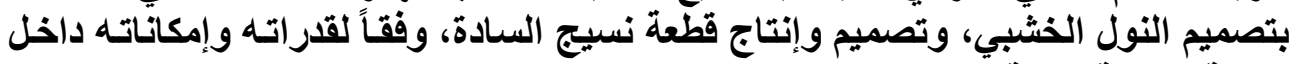

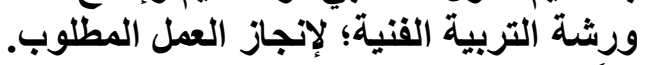

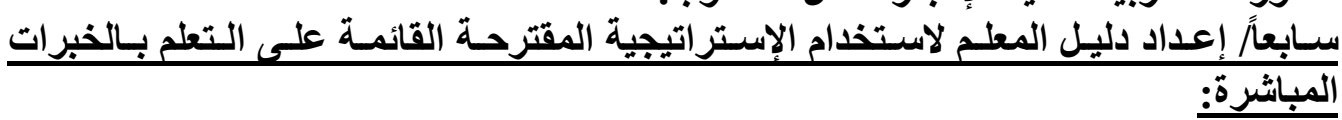
قام الباحِّث بإعداد دليل المعلم لاستخدام وتدريس مهارات الأداء الفني المتعلقة بتصميم

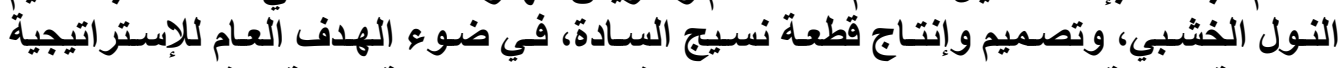

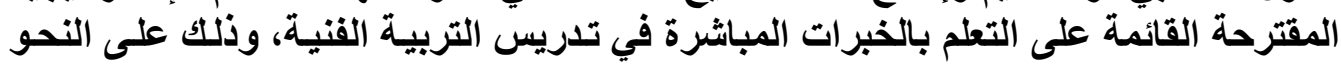


يهـف دليل المعلم إلى تحديد الأدوار التدريسية؛ لاستخدام وتوظيف الإستراتيجية التدريسية

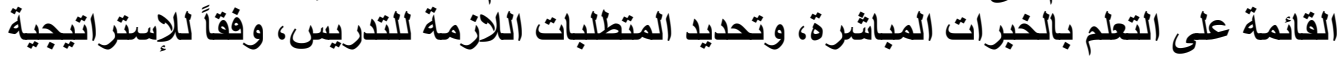

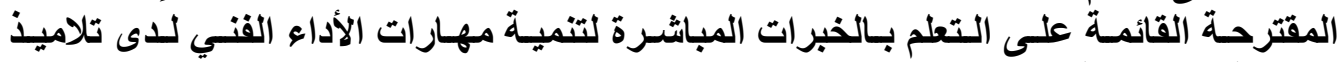
المرحلة المتوسطة.

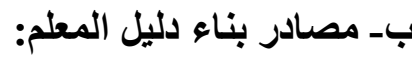
اعتمد الباحث على مجموعة من المعلى المصادر عند بناء دليل المعلم، وهي كالآتي :

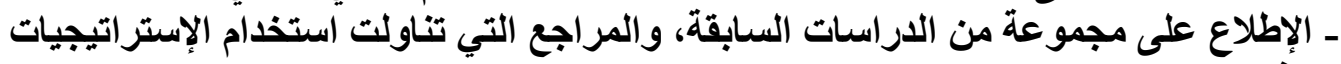

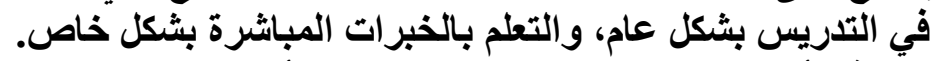
ـ ـ مراجعة الأدب التربوي المتعلق بتدريس مجال أثنغال النسيج.

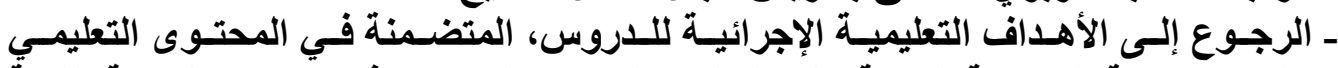

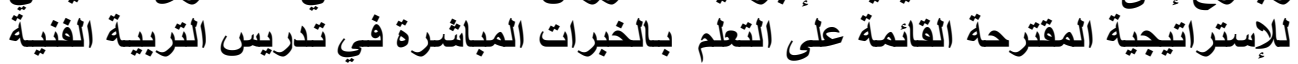

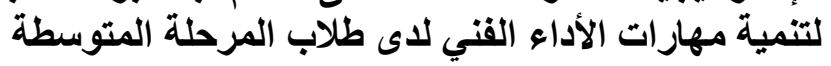

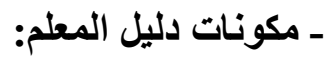
تكوّن دليل المعلم لتدريس مهار المعات الأداء القني المتعلقة بتصميم النول الخشبي، وتصميم

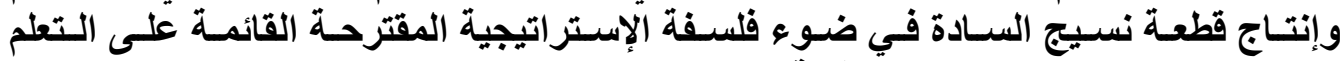

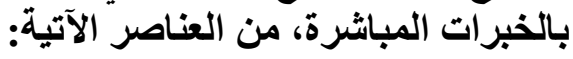

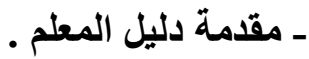
ـ ـ الأهداف العامة لاليل المعلم المعلم.

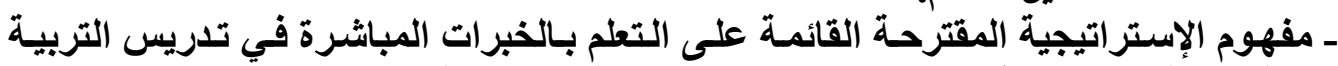

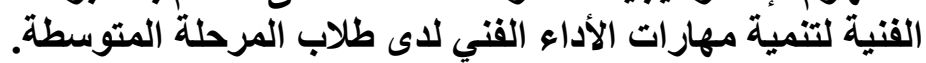

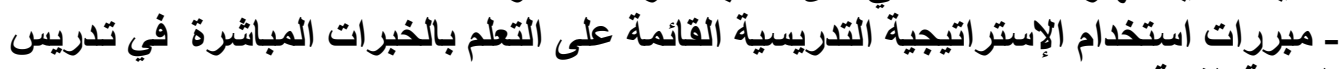
التربية القنية.

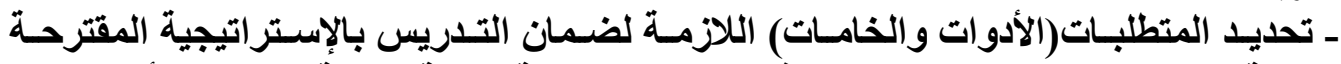

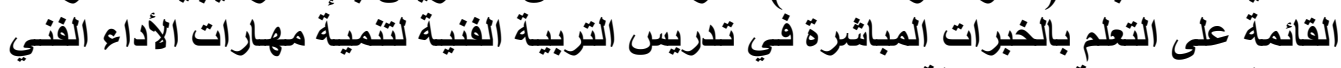

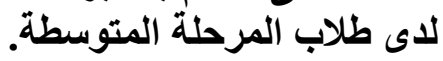
ـ تحديد أدوار المعلم في إدارة تعلم التلاميذ في بيئة التعلم القائمة على الخبرات المباشرة في

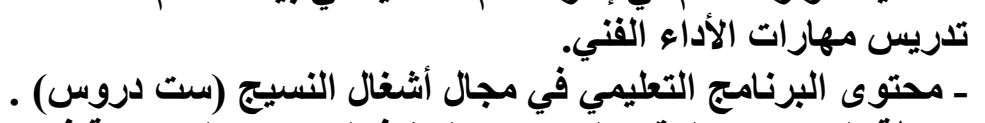

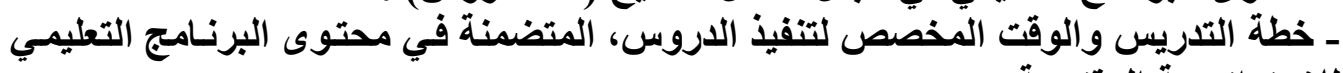
لـلإستر اتيجية المقترحة.

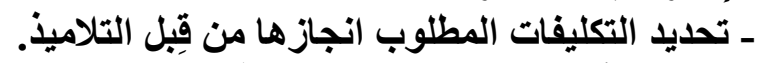

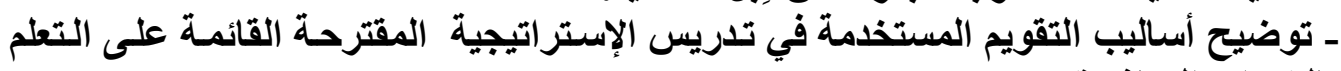
بالخبرات المباشرة.

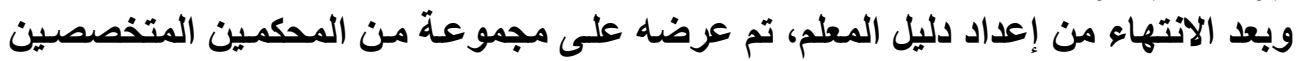

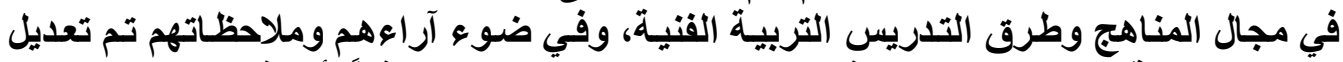

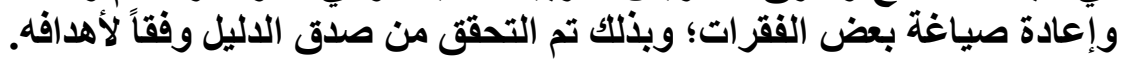


ثامناً تحديد طرق وأساليب التقويم في الإستر اتيجية المقترحة القائمة على التعلم بالخبر ات

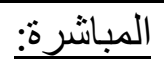

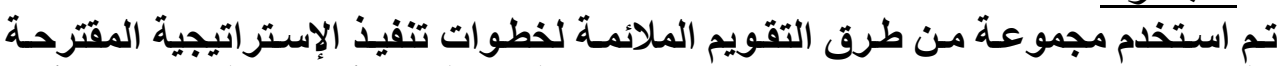

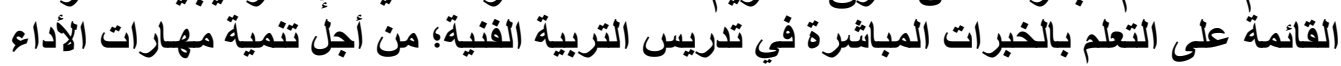

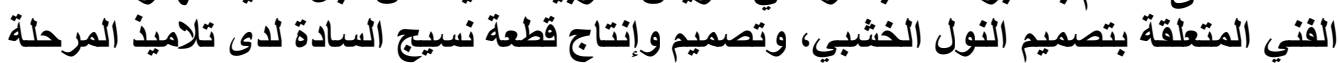

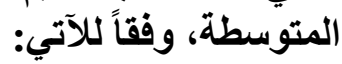

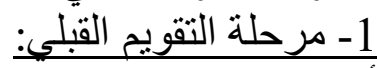

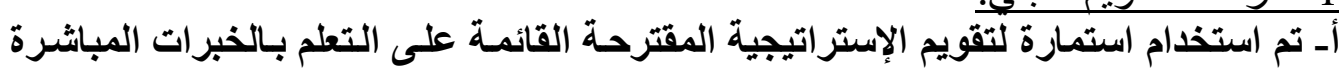

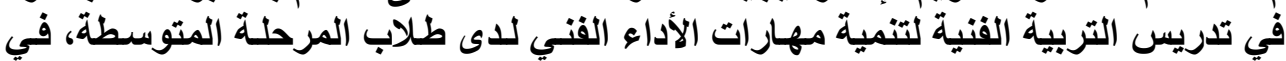

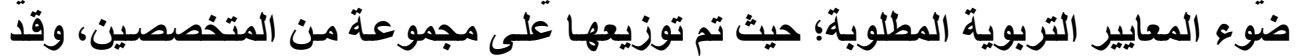

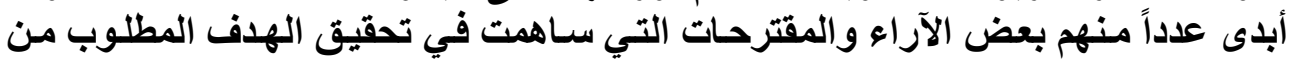

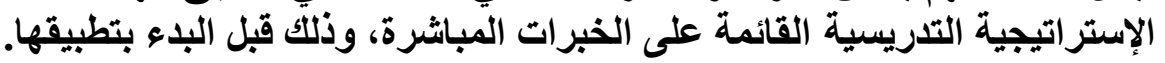




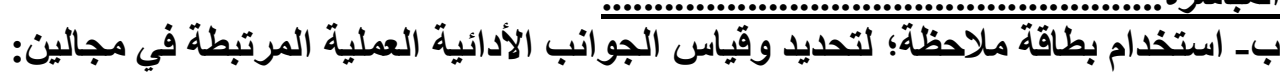

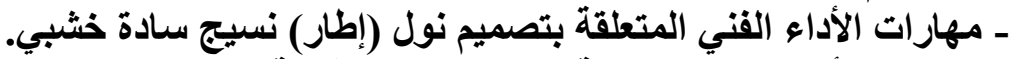

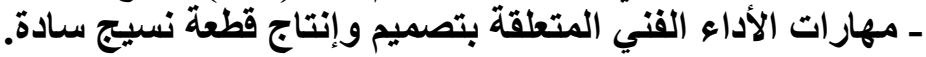

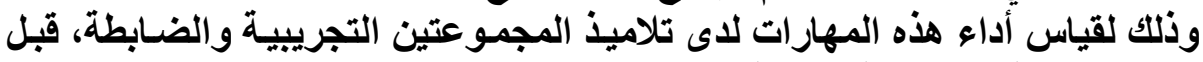

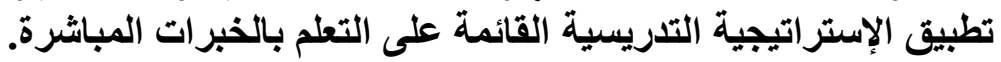

$$
\text { 2- مرحلة التقويم التكويني (البنائي): }
$$

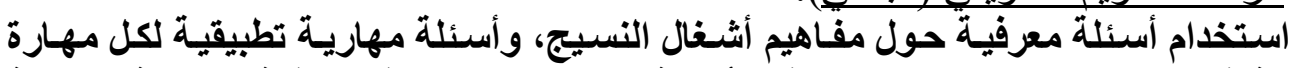

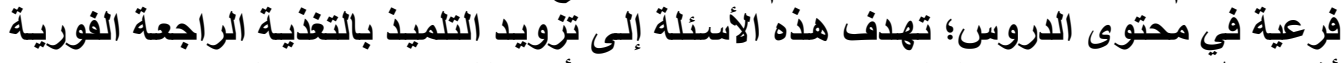

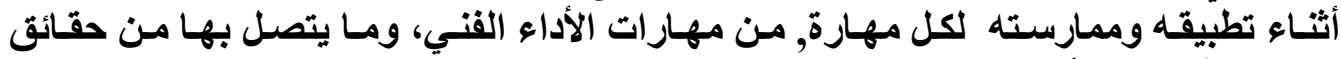
ومفاهيم في مجال أشغال النسيج.

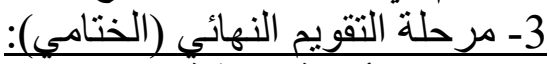

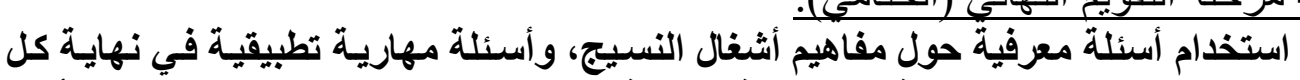

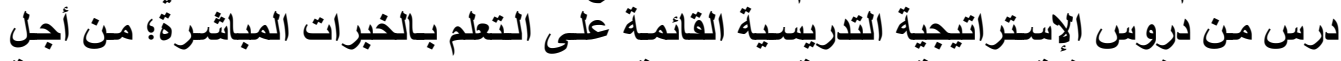

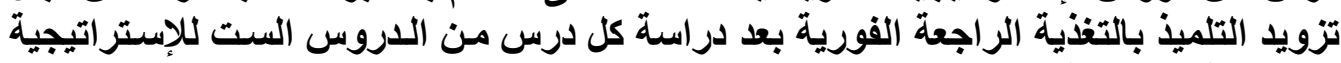
التربيسية المقترحة. 4- درحلة التقويم البعدي: تم استخدام بطاقة ملاحظة؛ لتحديد التعائ وقياس الجوانب الأدائية العملية المرتبطة في مجالين:

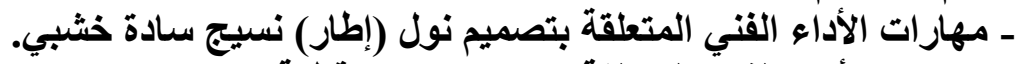

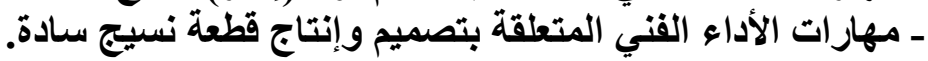

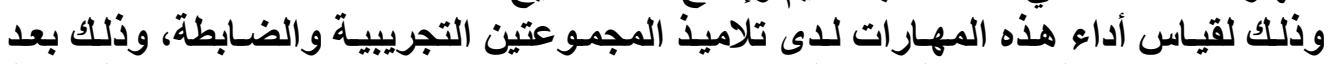

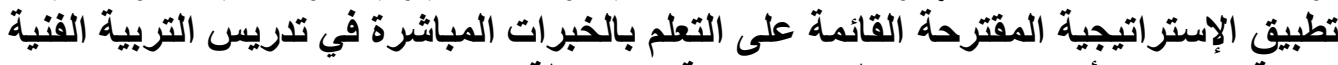

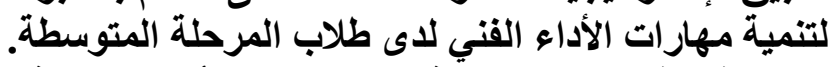

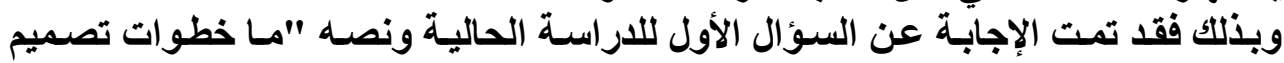

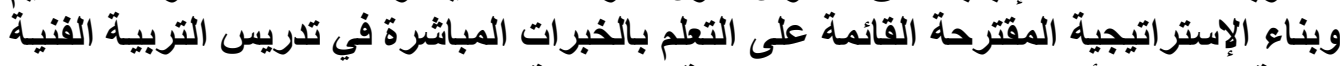

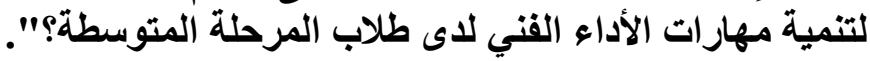

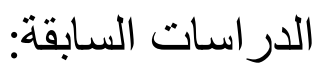

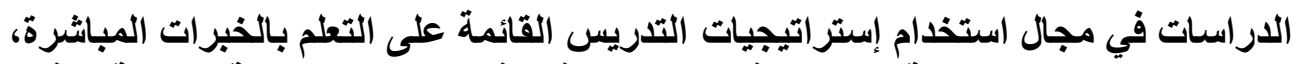

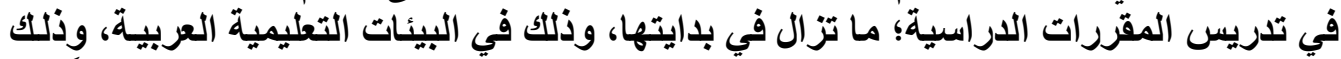

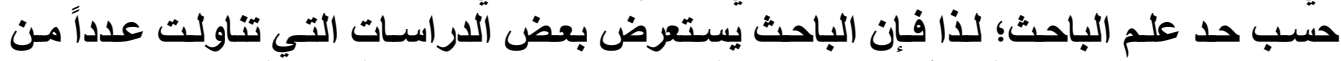

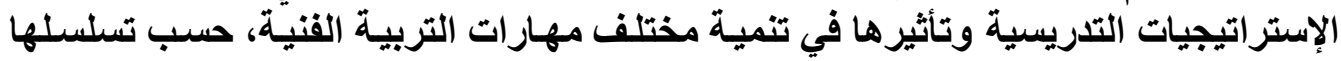

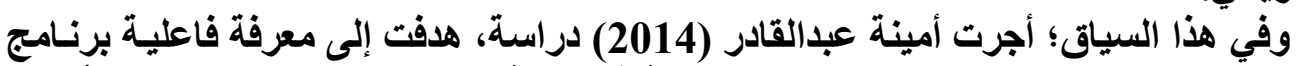

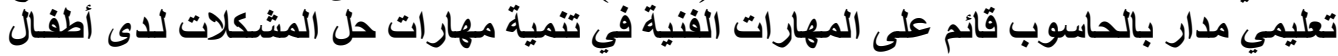

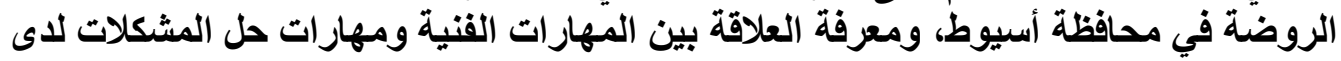

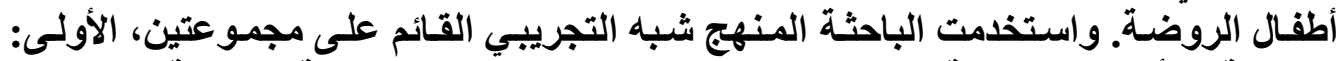

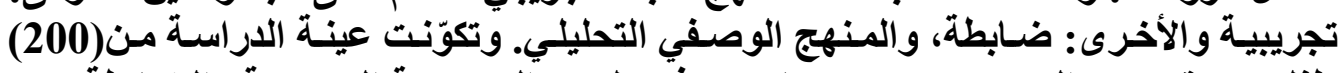

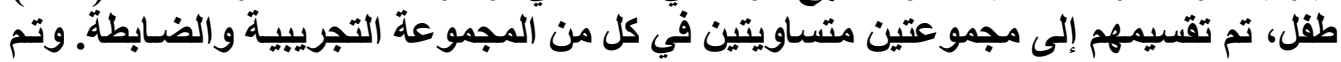




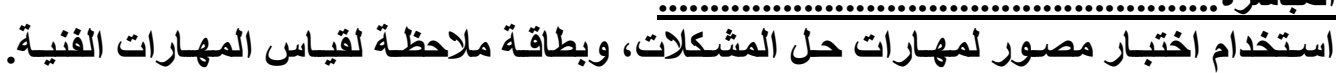

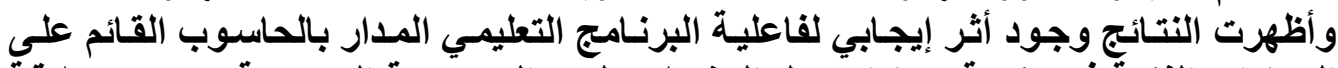

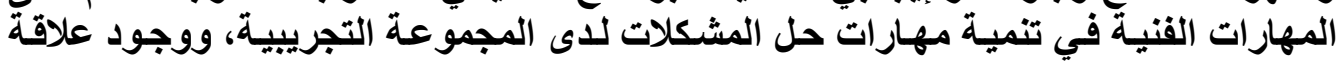

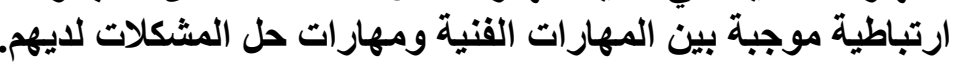

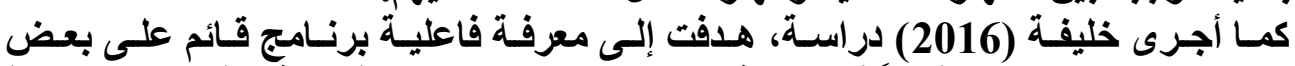

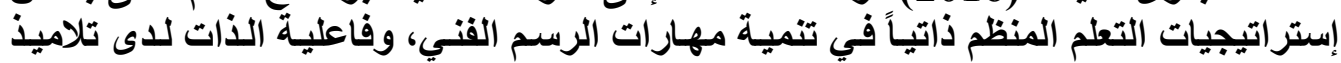

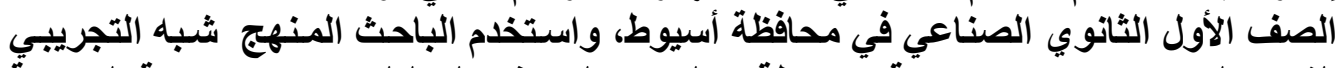

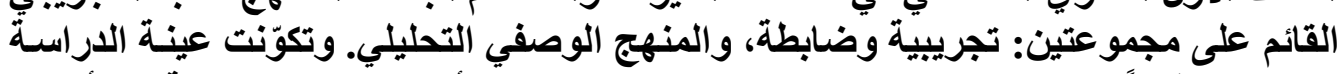

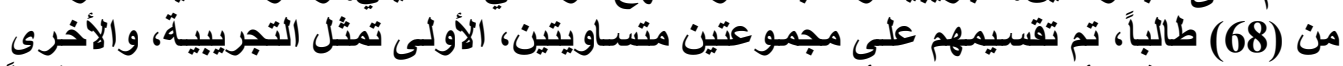

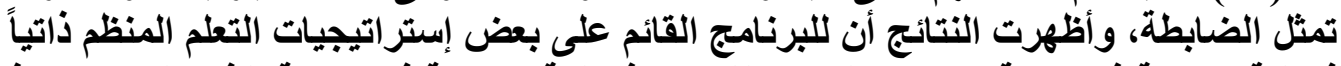

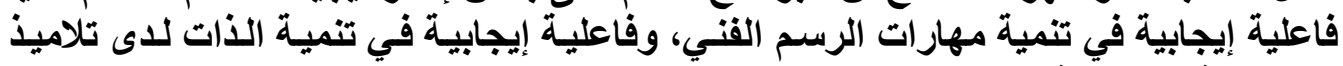
المجموعة التجريبية. 


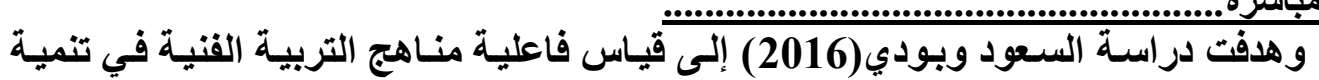

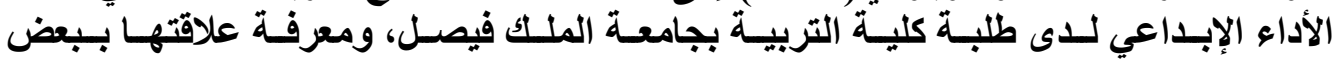

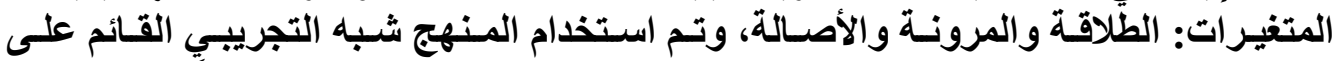

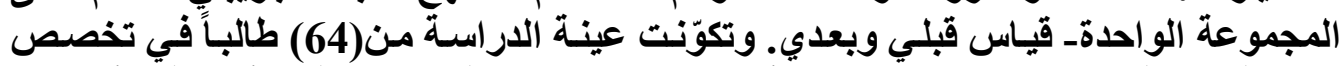

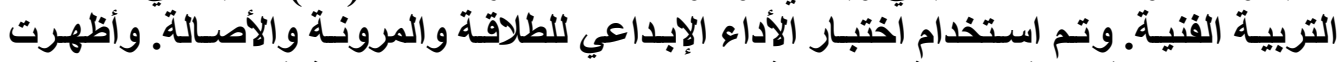

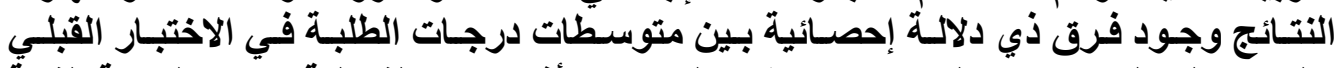

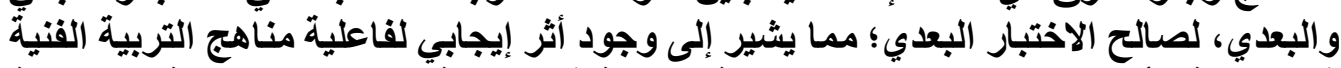

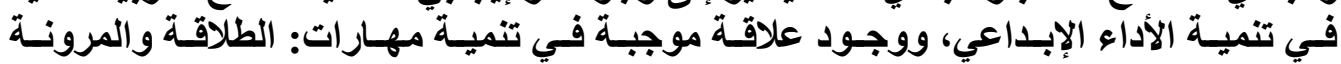

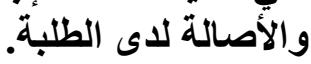

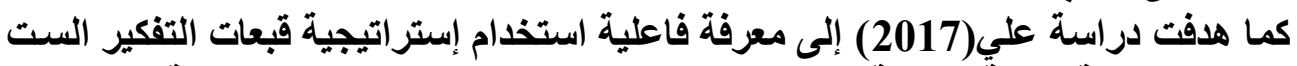

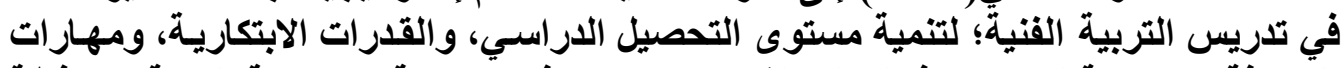

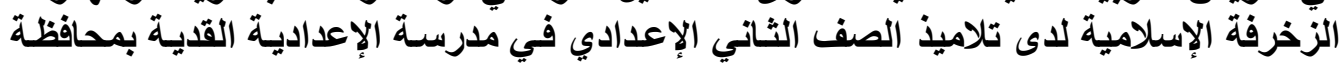

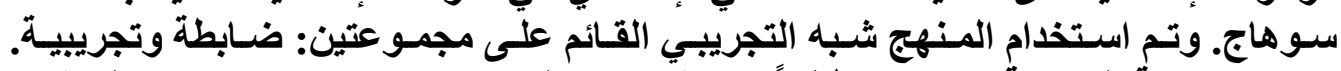

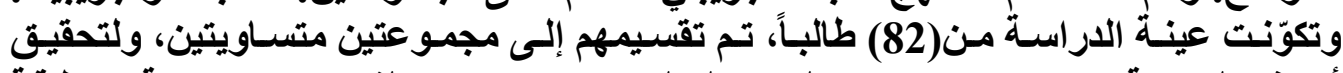

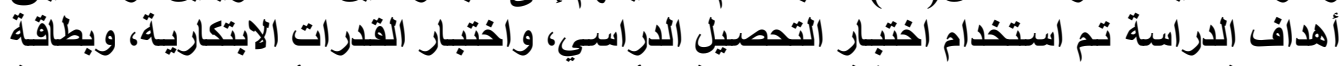

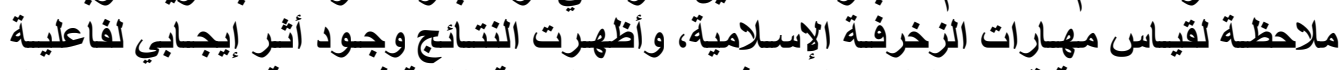

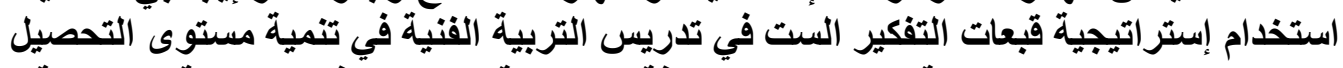

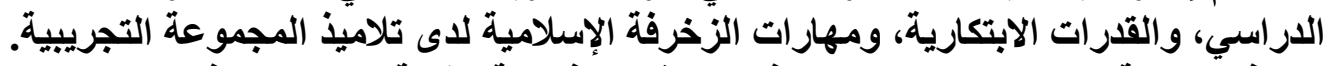

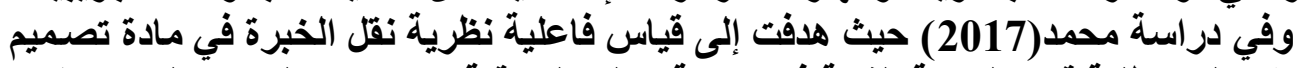

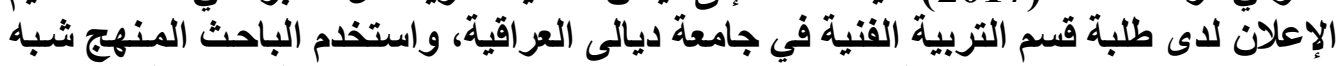

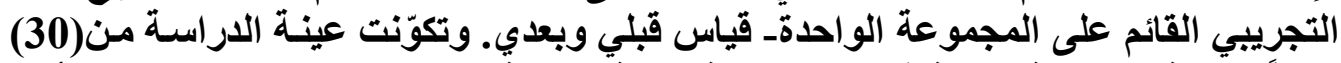

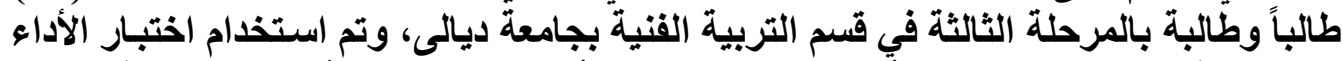

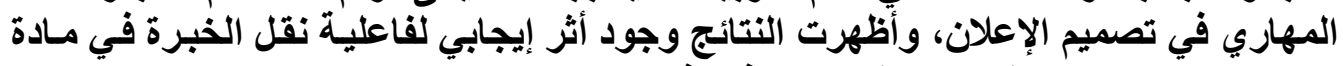

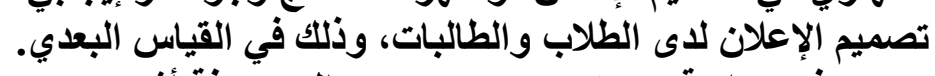

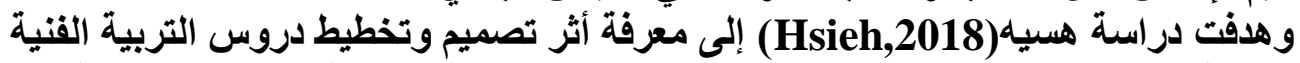

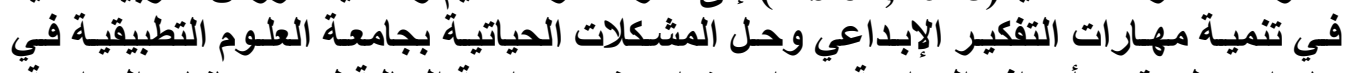

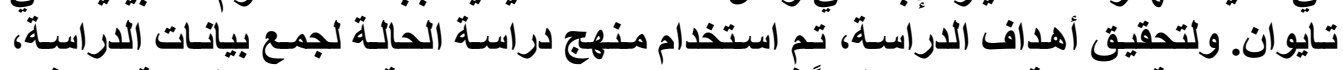

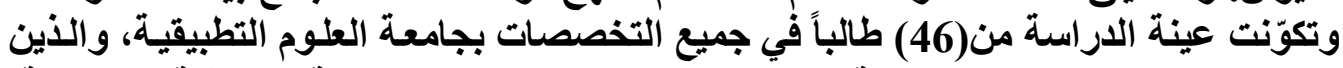

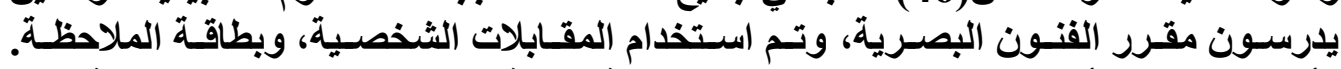

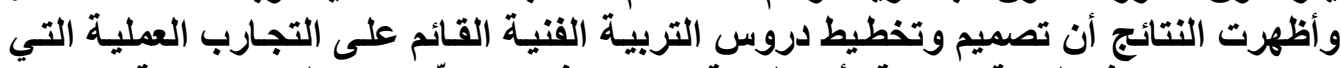

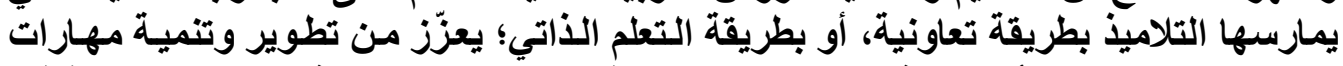

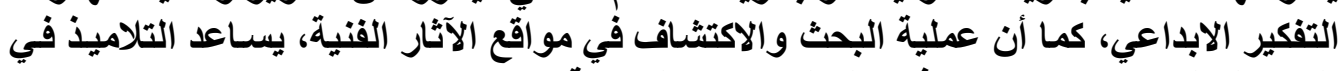

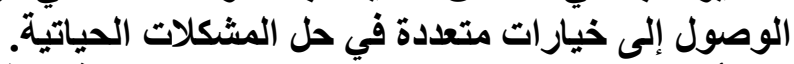

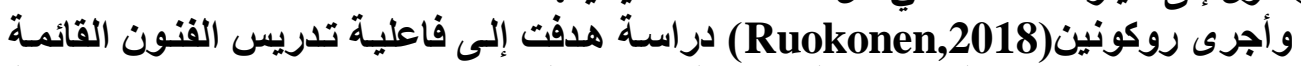

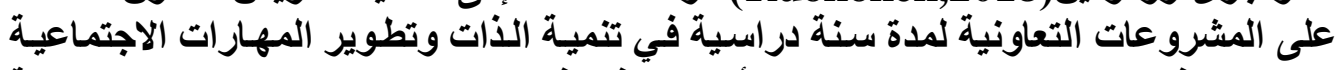

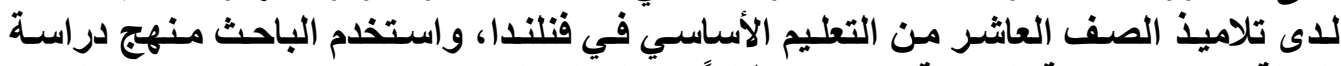

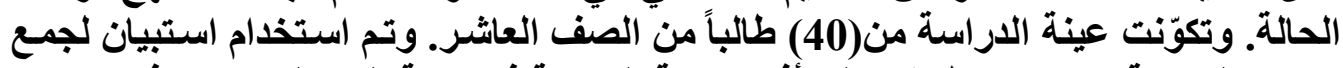
بيانات الدراسة؛ حيث تم تطبيقه على أفراد عينة الدراسة مينة في بداية العام الدراسي وفي نهايته، 


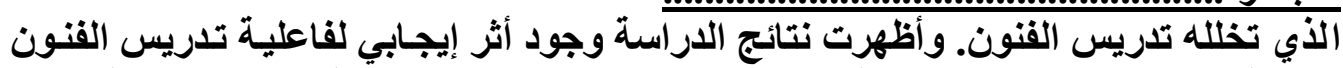

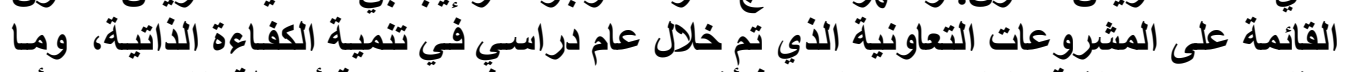

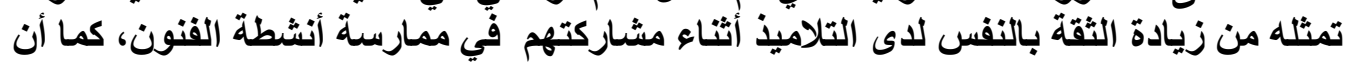

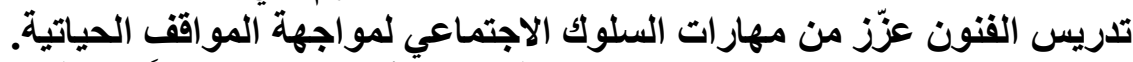

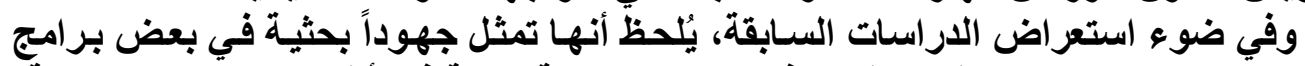

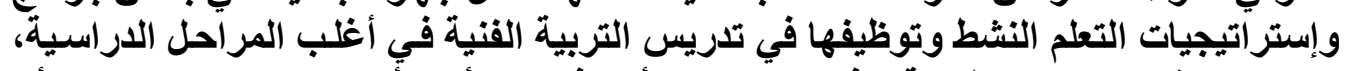

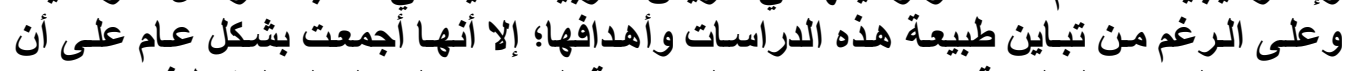

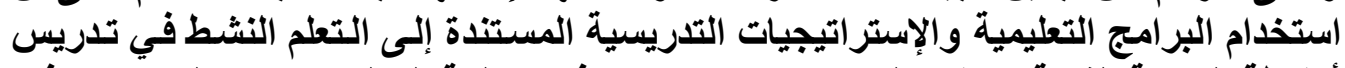

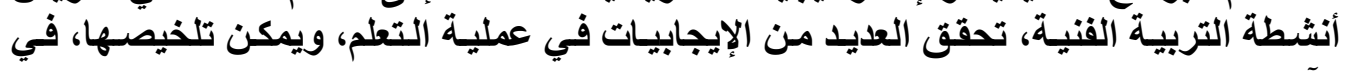




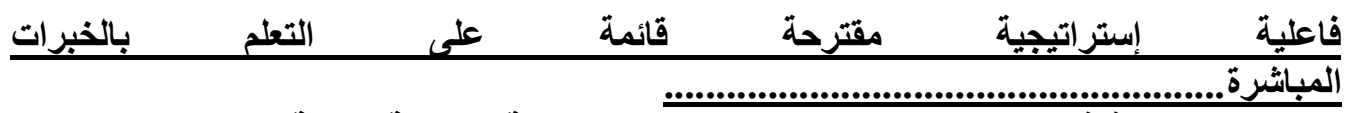

ـ تساعد التلاميذ في اكتساب مهارات حل المشكلات بطريقة تطبيقية عملية.

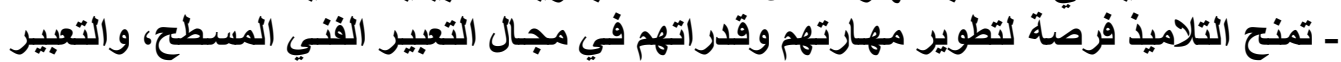
الفني المجسم، بثنكل إيجابي.

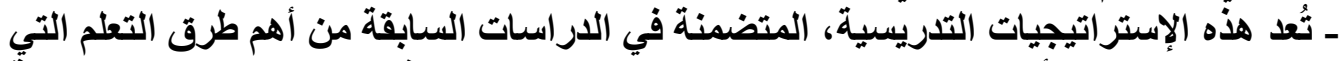

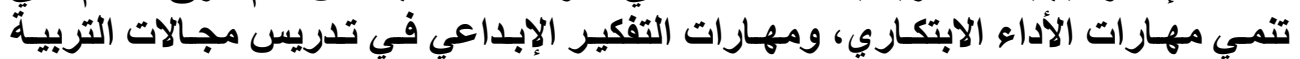
القنية. ـ تُعزز من تطوير القدرات الذاتية، والاعتماد على النفس في قيـام التلاميذ بالأعمـال اليدويـة، وزيادة الثقة بالنفس، والاستمتاع بممارسة الأعمال الفتية وإنية إنجازها.

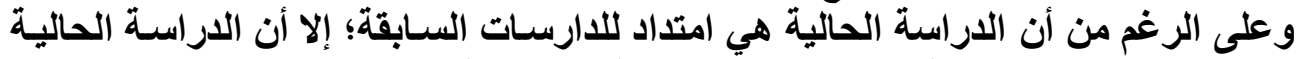

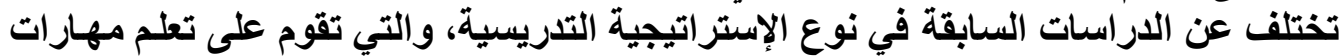

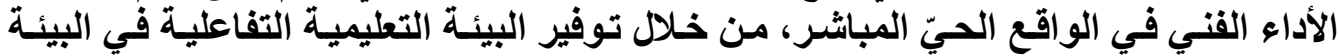

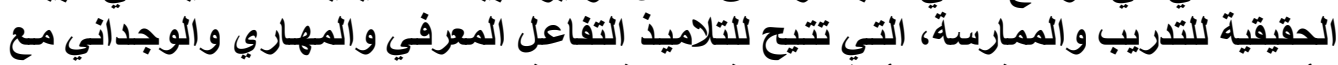
الأدوات والخامات الفتية، المهيأة في ورشية المئة التربية الفنية.

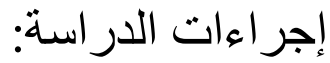

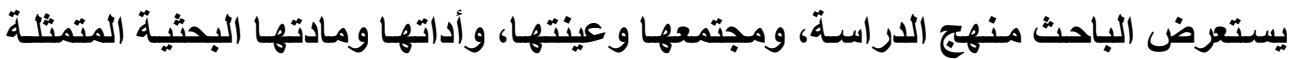

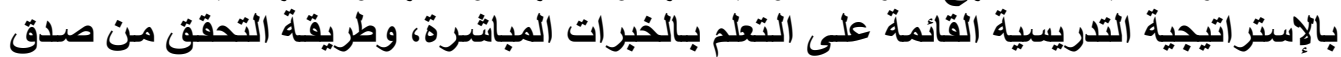

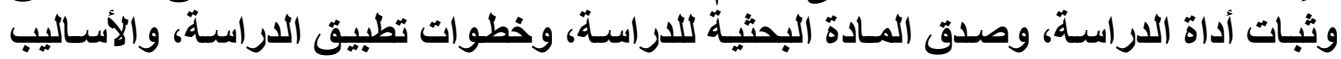

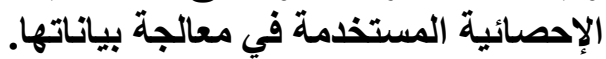

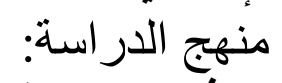

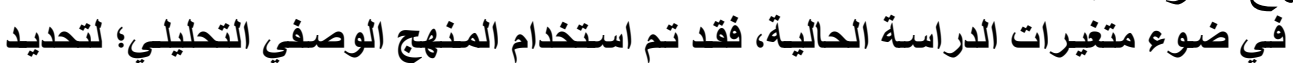

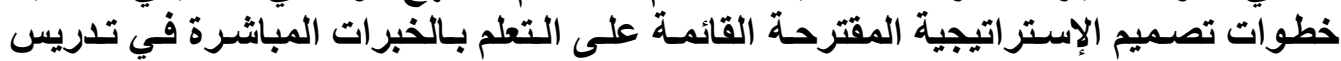

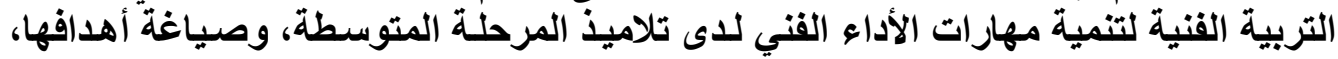

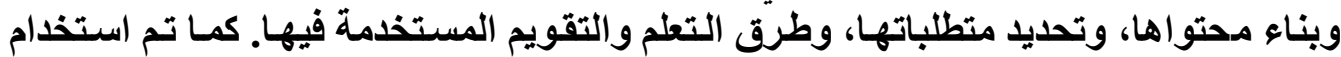

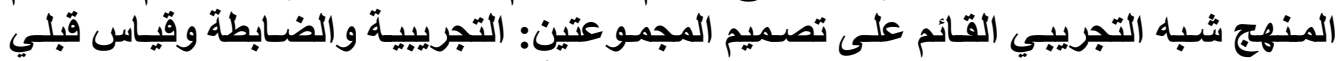

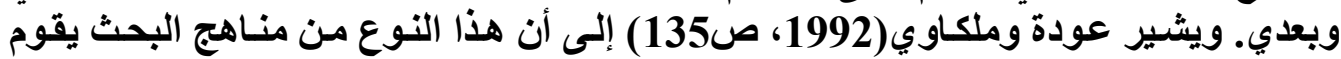

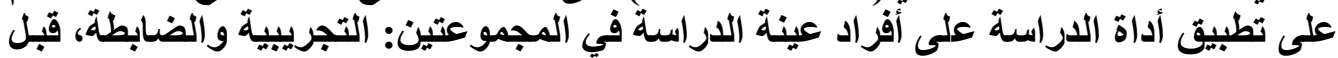

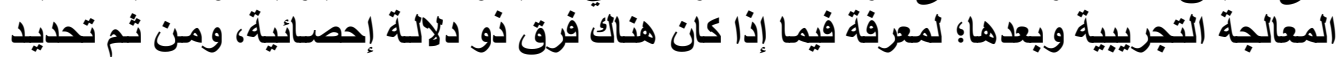
الفرق لصالح أي من المجموعتين. مجتمع الدر استة:

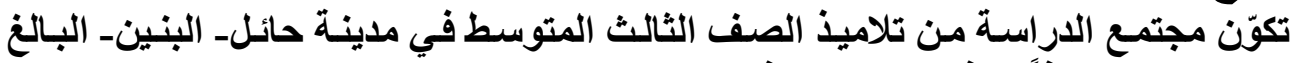

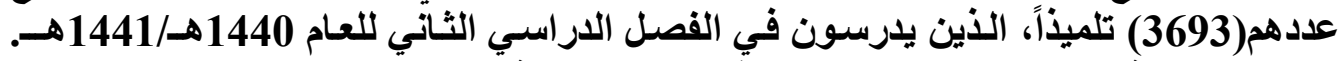

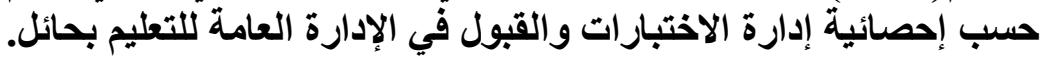

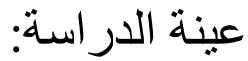
أ - عينة الدر اسة الاستطلة العية:

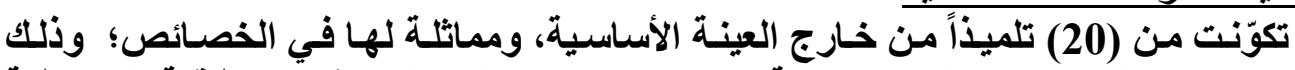

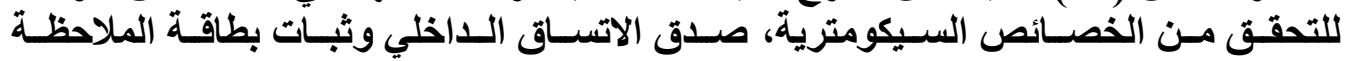
المستخدمة في الاراسة الحالية. 


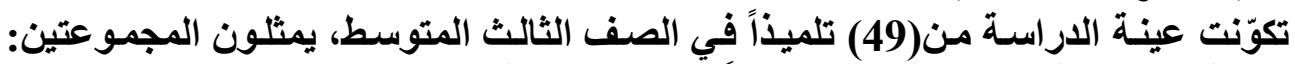

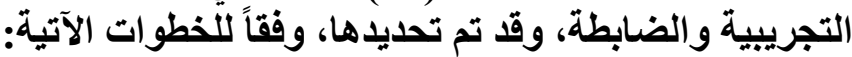

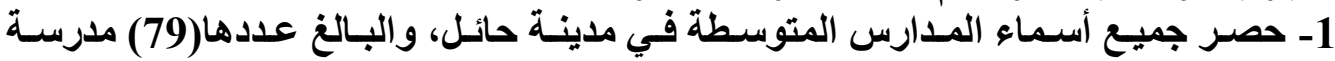
متوسطة.

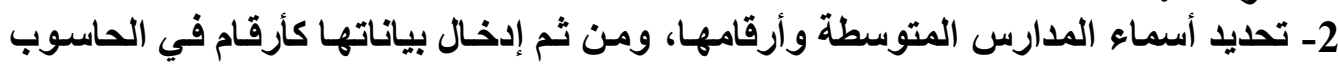

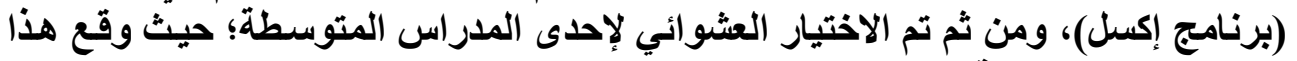

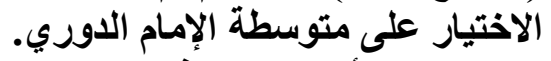

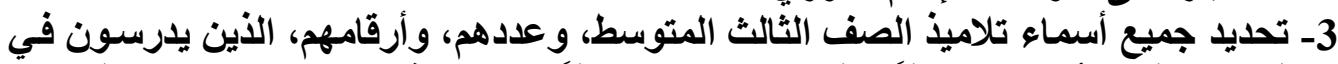

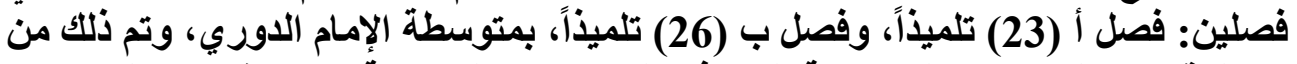

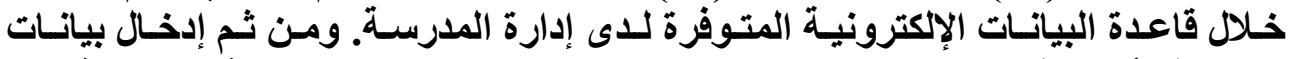

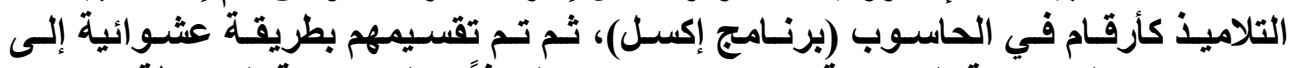

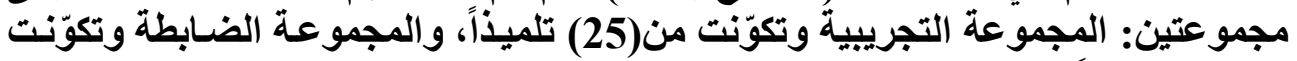
من(24) تلميذاً.

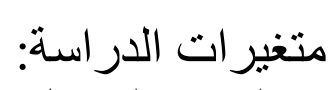

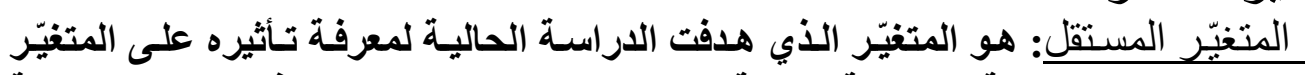

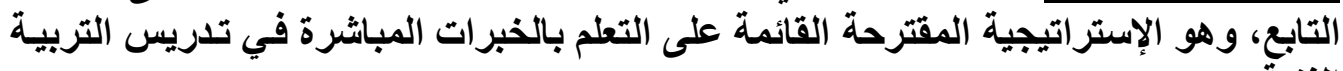
القنية.

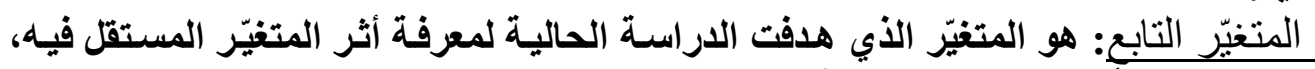

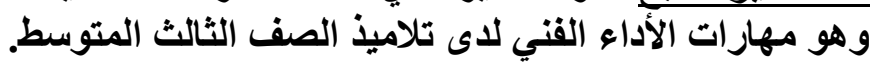

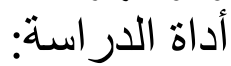
التحقيق أهداف الدراسة، قام الباحث بإعداد بطاقة ملاحظة لقياس الجواتب البأب الأدائية لمهارات

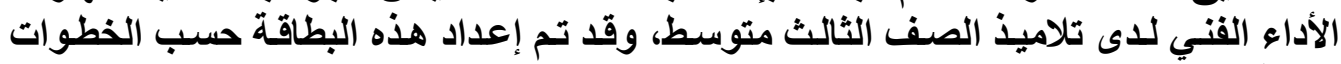
التالية: أـ تحديد هدفة بطاقة الملاحظة:

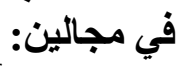
- مهار ـ مهات الأداء الفني المتعلقة بتصميم نول (إطار) نسيج سادة خشبي.

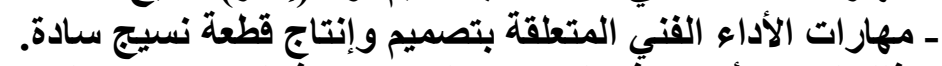

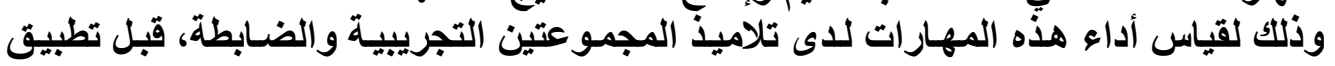

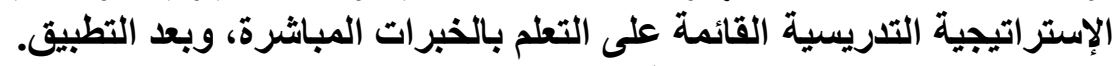

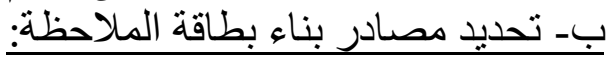
اعتمد الباحث على مجموعة من المصادر لإعداد الاعداد بطاقة ملاحظة الجواتب العملية لمهارات

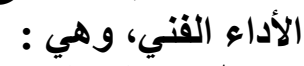
ـ الإطلاع على الأراسات السابقة التي قامت بإعداد بطاقـات ملاحظة لقياس الجوانب الأدائية المهارية. 


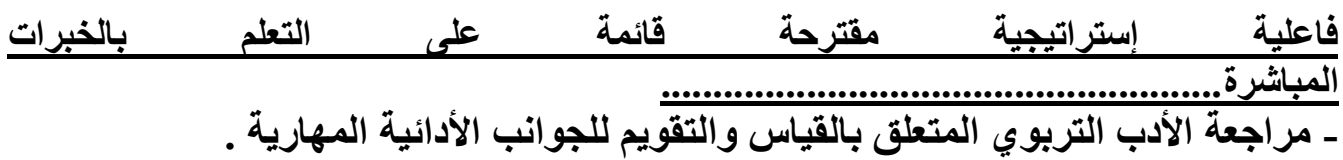




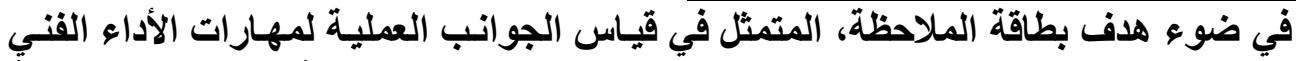

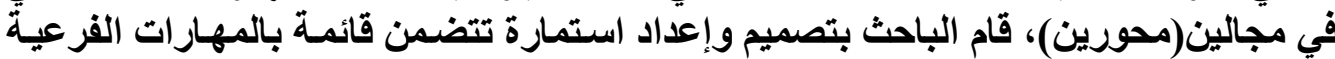

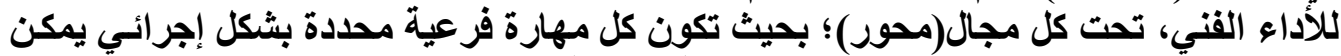

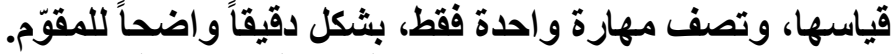

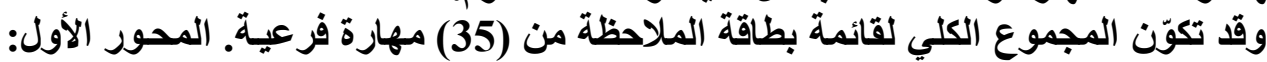

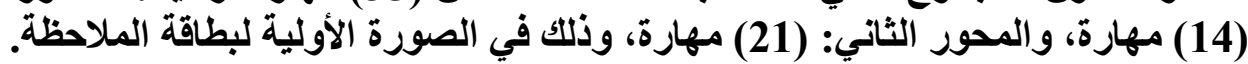
دـ صدق بطاقة الملاحظة:

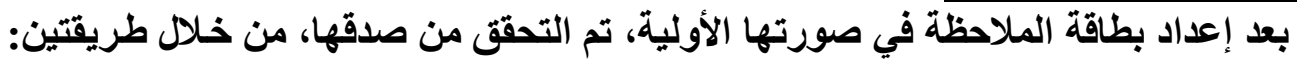

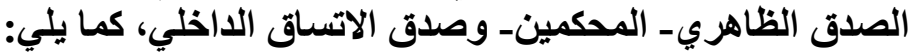

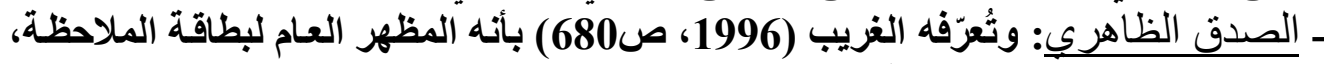

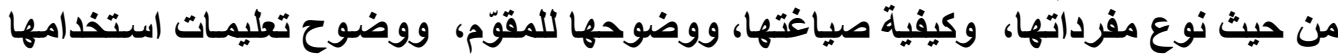

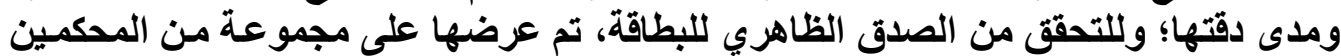

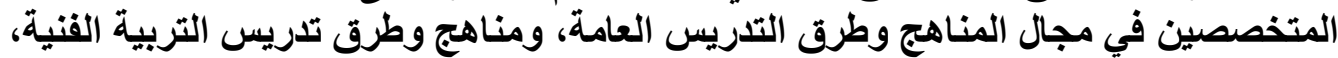

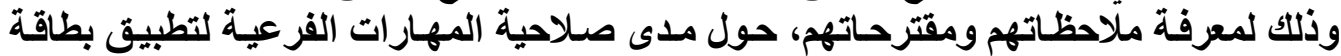

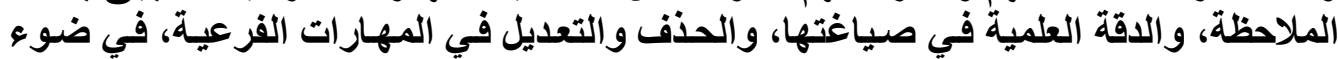

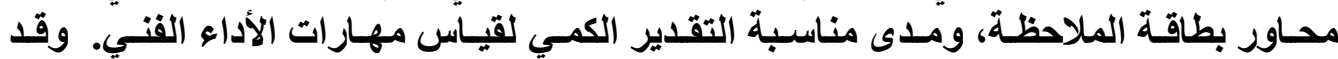

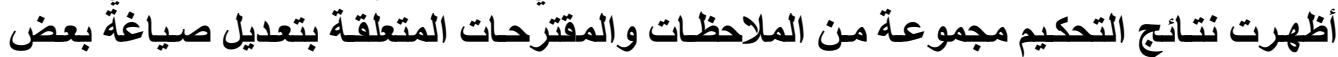

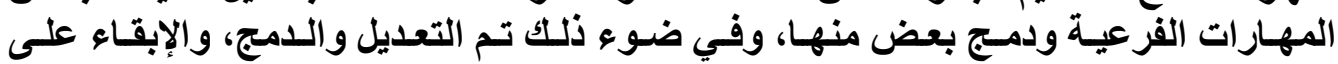

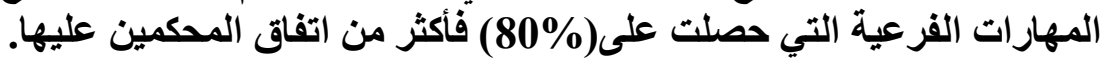

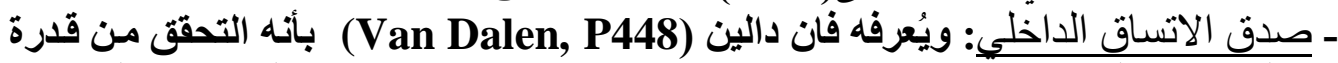

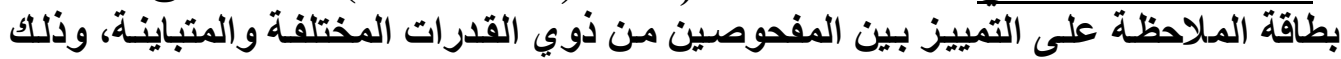

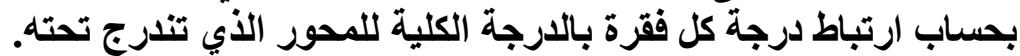

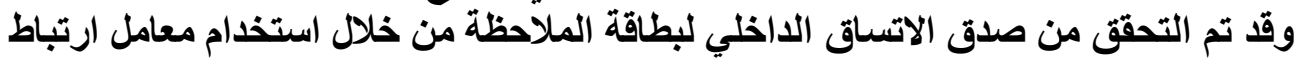

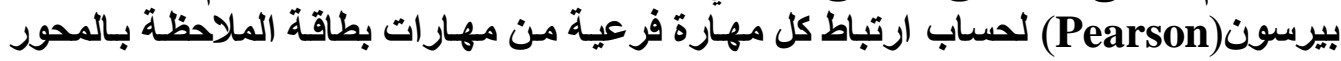
الأني تنتمي إليه.

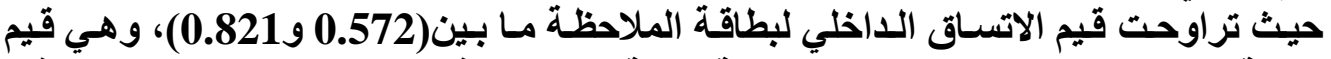

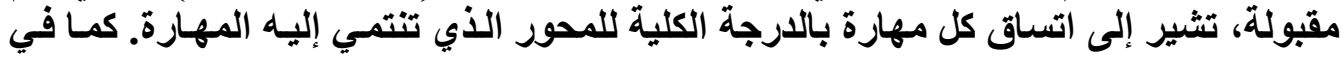

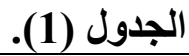

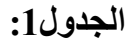

\begin{tabular}{|c|c|c|c|c|c|c|c|}
\hline \multicolumn{8}{|c|}{ معامل ارتباط بيزسون بين درجة مهارة فرعية من مهارات بطاقة الملاحظة بالمحور الذي تنتمي إليه } \\
\hline \multicolumn{4}{|c|}{ المهارات الفرعية للمحور الثاني } & \multicolumn{4}{|c|}{ المهارات الفرعية للمحور الأول } \\
\hline معامل ارتباط & رقم & معامل ارتباط & 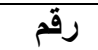 & معامل ارتباط & رقم & معامل ارتباط & رقم \\
\hline بيرسون & المهارة & بيرسون & المهارة & بيرسون & المهارة & بيزسون & المهارة \\
\hline$* * 0.802$ & 10 & $* * 0.590$ & 1 & $* * 0.697$ & 10 & $* * 0.781$ & 1 \\
\hline$* * 0.689$ & 11 & $* * 0.672$ & 2 & $* * 0.705$ & 11 & $* * \mathbf{0 . 8 2 1}$ & 2 \\
\hline$* * 0.729$ & 12 & $* * 0.630$ & 3 & $* * 0.813$ & 12 & $* * 0.764$ & 3 \\
\hline$* * 0.765$ & 13 & $* * 0.708$ & 4 & & & $* * 0.792$ & 4 \\
\hline
\end{tabular}




\begin{tabular}{|c|c|c|c|c|c|c|}
\hline بالخبرات & التعلم & على & قائمة & مقترحة & إستر اتيجية & فاعلية \\
\hline & & & & & 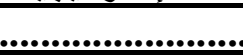 & المباشر \\
\hline$* * 0.619$ & 14 & $* * 0.814$ & 5 & & $* * 0.809$ & 5 \\
\hline$* * 0.597$ & 15 & $* * 0.766$ & 6 & & $* * 0.780$ & 6 \\
\hline$* * 0.732$ & 16 & $* * 0.572$ & 7 & & $* * 0.735$ & 7 \\
\hline$* * 0.812$ & 17 & $* * 0.620$ & 8 & & $* * 0.711$ & 8 \\
\hline$* * 0.685$ & 18 & $* * 0.710$ & 9 & & $* * 0.802$ & 9 \\
\hline
\end{tabular}

* * الارتباط ذو دلالة إحصائية عند مستوى دلالة (0.01)

هـ ثبات بطاقة الملاحظة:

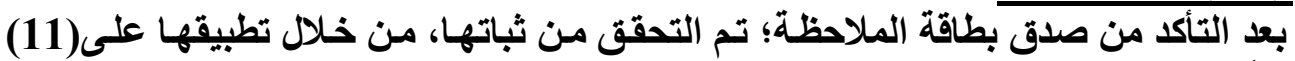

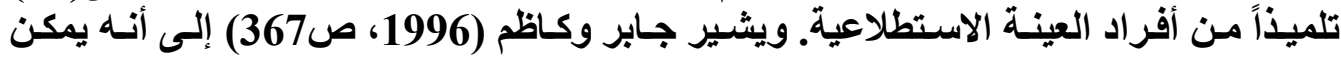

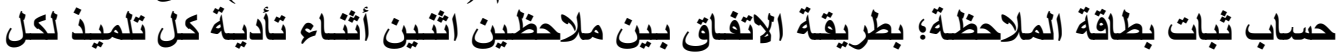

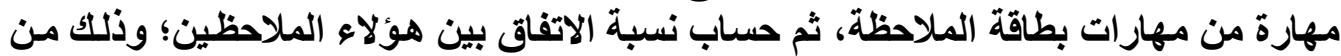

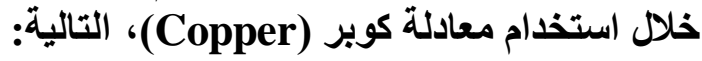

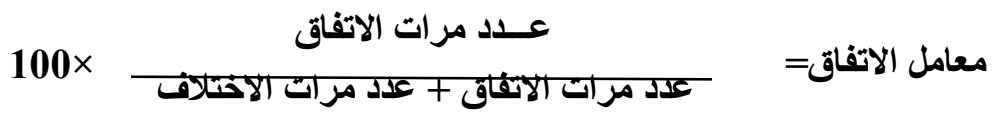

وبناءً على ما سبق، تمث الاستعانة بأثنين من معلمي التربية الفتية، وتم الاتفاق على معايير

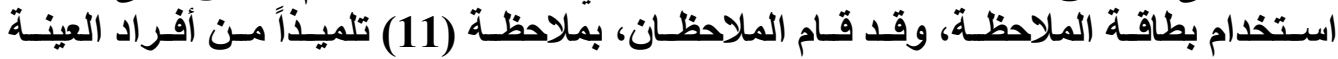

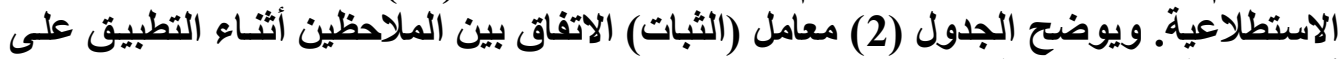

أفراد العينة الاستطلاعية.

\begin{tabular}{|c|c|c|c|c|}
\hline \multicolumn{5}{|c|}{ معامل ثبات بطاقة الملاحظة: } \\
\hline المتوسط العام & (لنسبة المئوية & رقلميذ & (لنسبة المئوية & راتميذ \\
\hline \multirow{6}{*}{$\% 89.90$} & $\% 86.60$ & 7 & $\% 95.56$ & 1 \\
\hline & $\% 91.22$ & 8 & \%92.87 & 2 \\
\hline & $\% 88.03$ & 9 & $\% 88.62$ & 3 \\
\hline & $\% 89.19$ & 10 & $\% 93.15$ & 4 \\
\hline & \multirow{2}{*}{$\% 87.71$} & \multirow{2}{*}{11} & \%85.92 & 5 \\
\hline & & & $\% 90.09$ & 6 \\
\hline
\end{tabular}

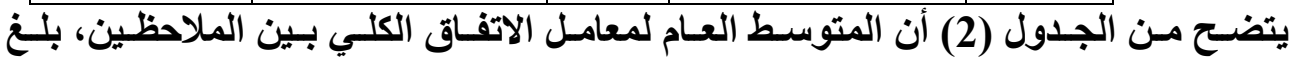

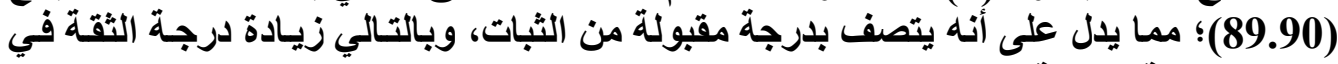
نتائج الاراسة الحالية.

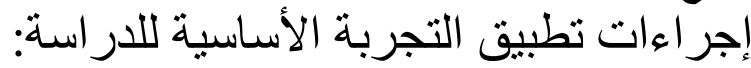

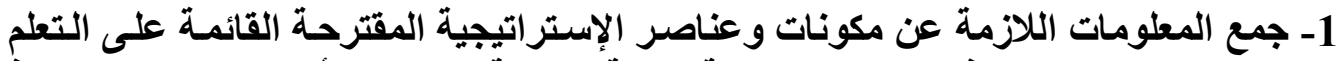

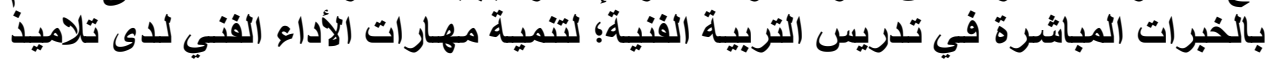




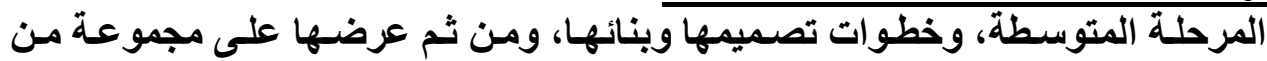

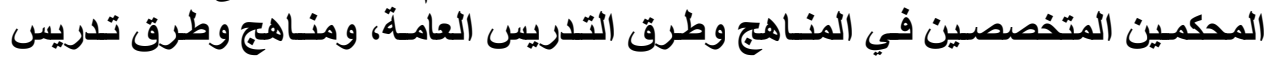

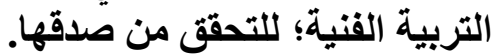

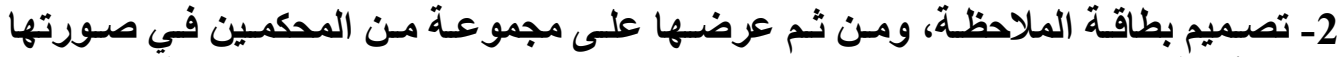

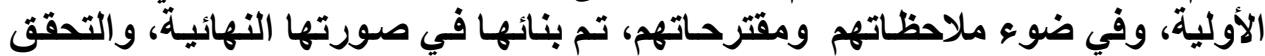
من صدقها وخثباتها. 3- اختيار عينة الدراسة بالطريقة العشوائية, وقد تكونت من (49) تلميذاً يمثلون المجموعتين

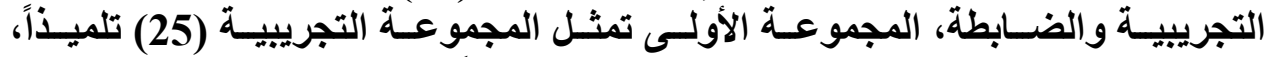

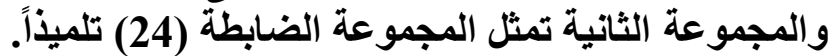

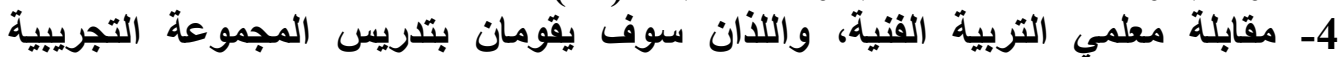

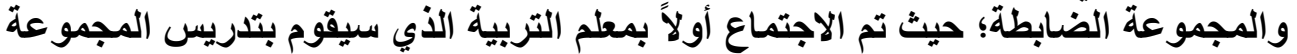

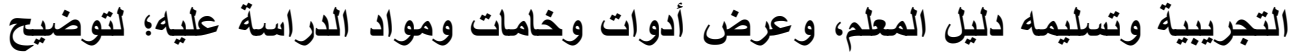

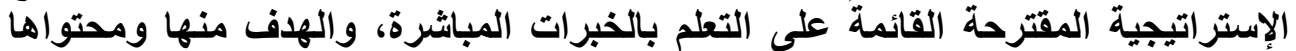

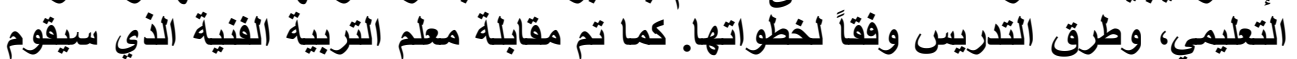

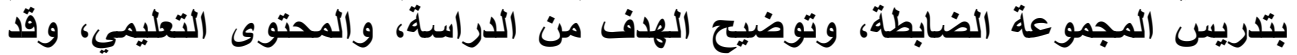
أبلى كل منهما تعاونه التام واستعداده في تتفيذ الإستراتيجية التدريسية المقترحة؛ لتحقيق والتيق

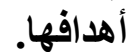
5- تطبيق القياس القبلي- بمساعد معلمي التربية الفنيةـ للجوانب العملية لمهارات الأداء

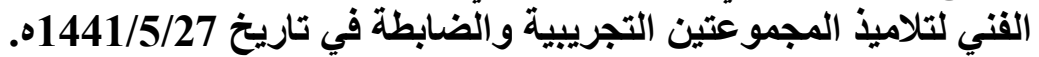

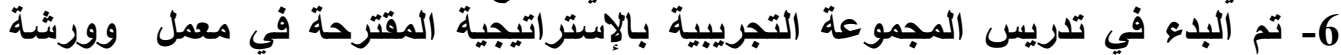

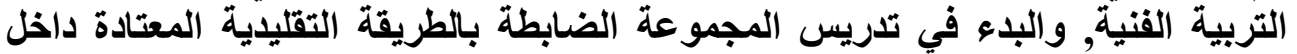

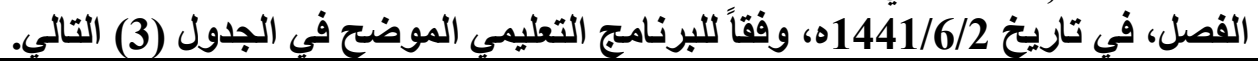

\begin{tabular}{|c|c|c|c|}
\hline \multicolumn{4}{|c|}{ البرنامج التعليمى لتطبيق التجربة الأساسية للاراسة } \\
\hline الموضوع & الز الزمنية & التاريخ & اللقاء \\
\hline تطبيق القياس القبلي لمهارات الأداء الفني(بطاقة الملاحظة) & ثلاث ساعات & $01441 / 5 / 27$ & الأول \\
\hline تصميم نول(إطار) النسيج السادة الخشبي مقاس30 سم × 40 & 90 دقيقة & $01441 / 6 / 2$ & الثاني \\
\hline قص وتفريغ نول(إطار) النسيج الخشبي. & 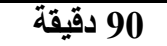 & $01441 / 6 / 9$ & الثالث \\
\hline هندسية. & 90 دقيقة & $\bullet 1441 / 6 / 16$ & 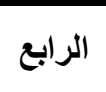 \\
\hline تسدية نول النسيج السادة. & 90 دقيقة & $01441 / 6 / 23$ & الخامس \\
\hline توليف خيوط اللحمة لإتتاج قطعة نسيج السادة. & م0 90 دقيقة & $\Delta 1441 / 6 / 30$ & الساس \\
\hline إكمال الدارس الخامس: توليف خيوط اللحمة لإتتاج قطعة & 90 & ه1441/7/7 & 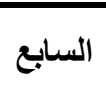 \\
\hline تطبيق القياس البعدي لمهارات الأداء القني(بطاقة الملاحظة). & ثلاث ساعات & 01441/7/9 & الثامن \\
\hline
\end{tabular}




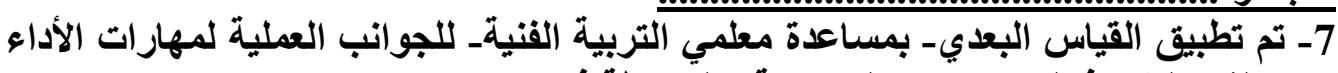

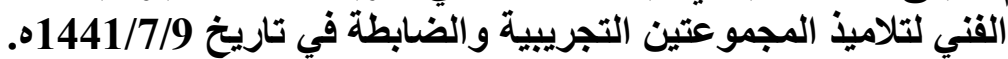

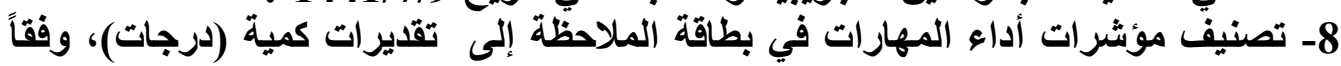

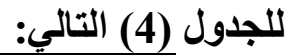

\begin{tabular}{|c|c|}
\hline \multicolumn{2}{|c|}{ تصنيف مؤشرات أداء المهارات إلى تقليرات كمية (درجات) } \\
\hline التقاير الكمي( اللارجات) & مستوى أداء التلميذ للمهارة \\
\hline صفر & لم يتقن \\
\hline 1 & أتقن بشكل متوسط \\
\hline 2 & أتقن بشكل تام \\
\hline
\end{tabular}

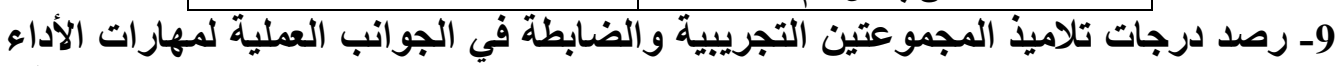

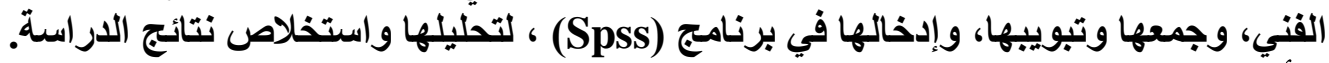

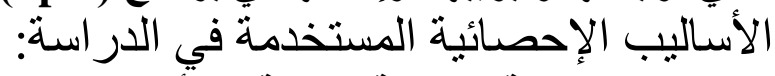

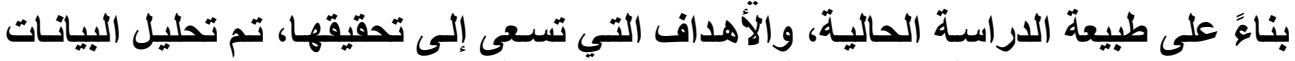

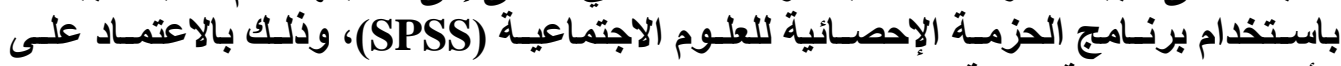
الأساليب الإحصائية التالية: - معامل ارتباط بيرسون (Pearson)؛ للتحقق من صدالية الإحتة الاتساق الداخلي لبطاقة الملاحظة.

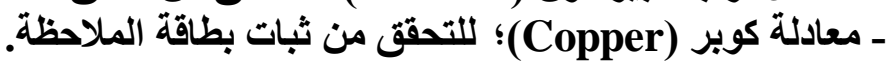

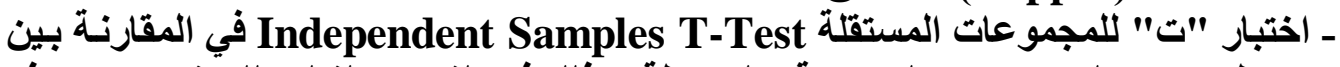

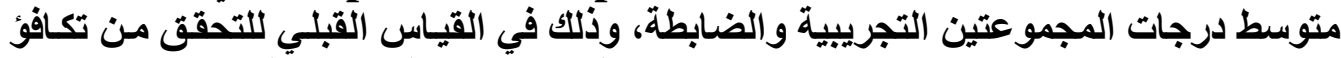
المجموعتين، وفي القياس البعدي للتحقق من فاعلية التئية الاستر اتيجية المقترحة.

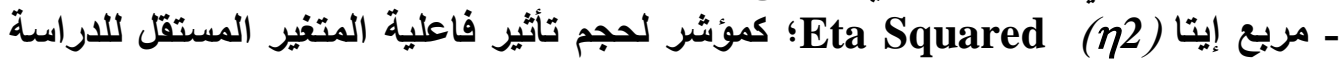

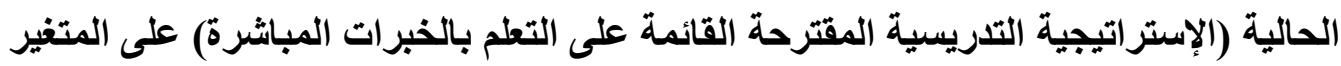

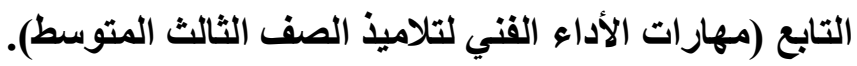




\begin{tabular}{|c|c|c|c|c|c|c|}
\hline بالخبرات & التعلم & على & قائمة & مقترحة & إستر اتيجية & فاعلية \\
\hline
\end{tabular}

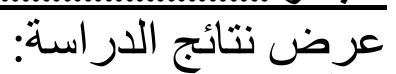

أولاً/ عرض نتائج السؤال الأول: مـا خطوات تصميم وبنـاء الإسـتراتيجية المقترحة القائمسة

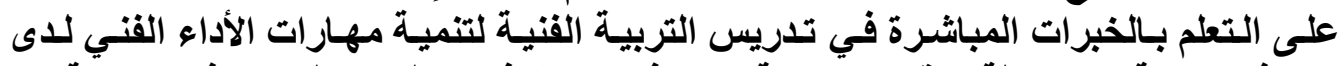

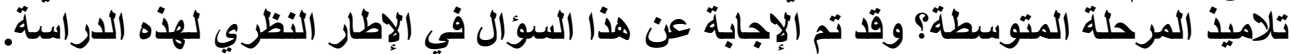

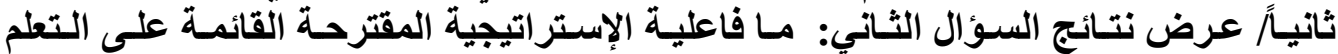
بالخبرات المباشرة في تدريس التربية الفنية لتنمية مهارات الأداء الفني لتصميم نـول (إطلار)

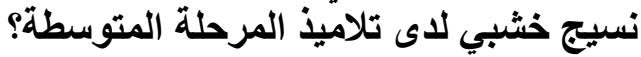

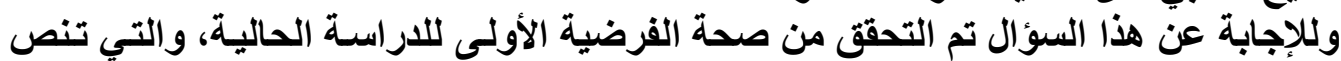

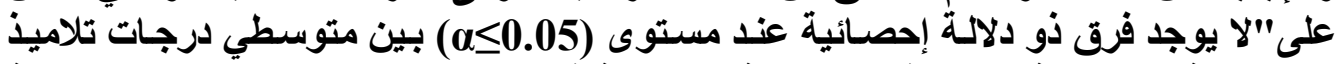

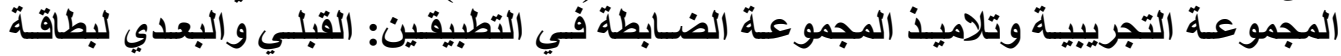

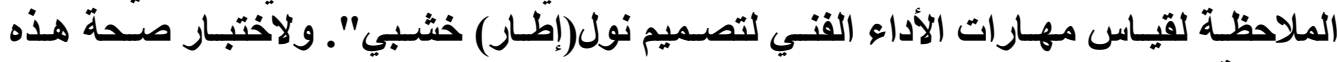

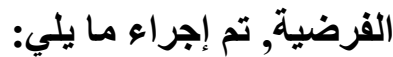
1- التحقق من تكاقؤ المجموعتين التجريبية والضابطة في القياس القبلي لمهارات الأداء القني

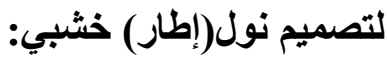

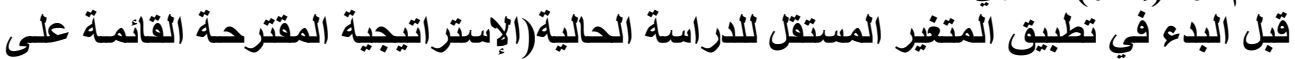

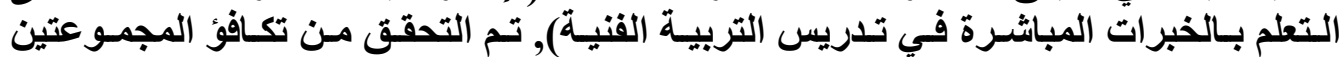

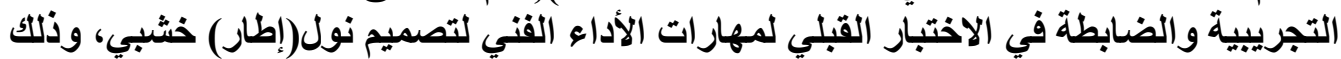

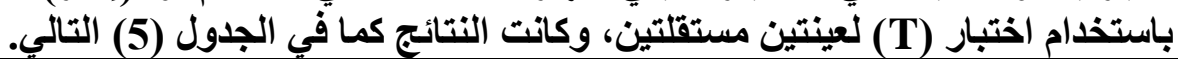

\begin{tabular}{|c|c|c|c|c|c|c|c|}
\hline غابطة في & تجريبي & جمو عتير & جات تلامبي & 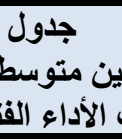 & لمقهار & لقيتقاس القين & نتائج اختبار(T) \\
\hline الإحصائية & الحرية & قيمة & الاتحرياري & الحستوسط & العدد & المجموعة & المقارنة \\
\hline \multirow{2}{*}{0.906} & \multirow{2}{*}{47} & \multirow{2}{*}{0.119} & 0.831 & 2.760 & 25 & التجريبية & \multirow{2}{*}{ لتصهيم نول خثار الأداء القني } \\
\hline & & & 1.021 & 2.792 & 24 & الضابطة & \\
\hline
\end{tabular}




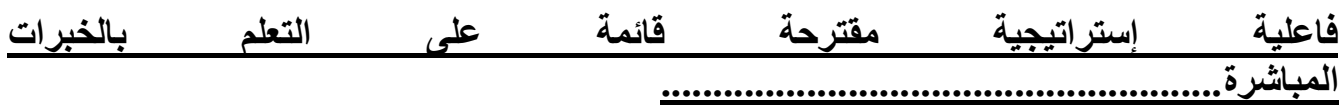

يتضـح من الجدول (5) أن المتوسط الحسبابي لدرجات تلاميذ المجموعة التجريبية يسـاوي

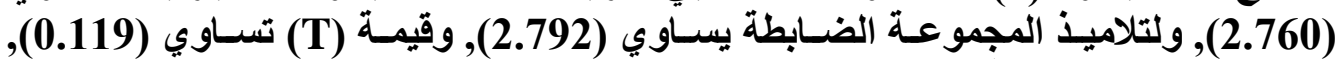

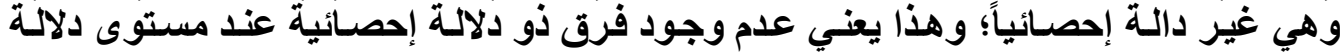

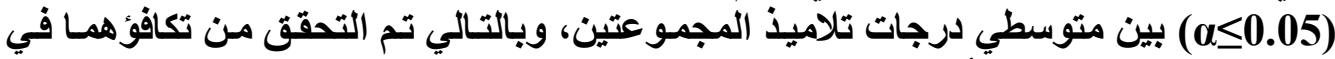

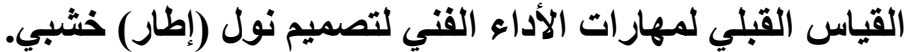

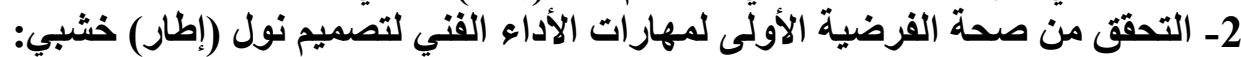

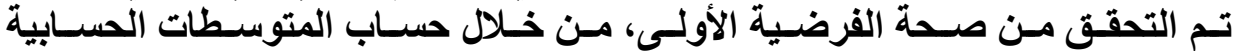

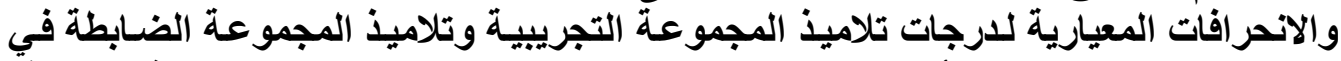

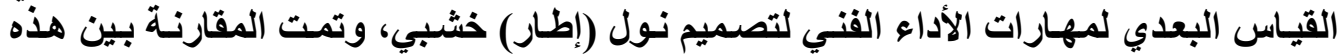

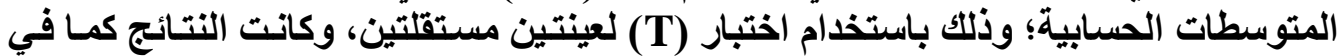
الجدول (6) التالّي.

\begin{tabular}{|c|c|c|c|c|c|c|c|}
\hline بية والضابطة في & خشبين الت & خميذ المجا & ول6 & لمهارنة بين & البين لا & لعينتين مسد & تتائج اختبار(5) \\
\hline الدلالة الإحصائية & الحرية & قيمة & الالمعراف & الحستوسطي & العدد & المجموعة & المقارنة \\
\hline \multirow[b]{2}{*}{0.01} & \multirow[b]{2}{*}{47} & \multirow[b]{2}{*}{28.923} & 1.964 & 15.240 & 25 & التجريبية & \multirow{2}{*}{ مهنار ات الأداء إطار) } \\
\hline & & & 0.741 & 2.875 & 24 & الضابطة & \\
\hline
\end{tabular}

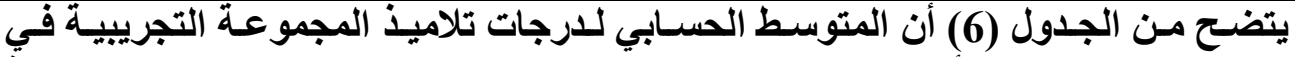

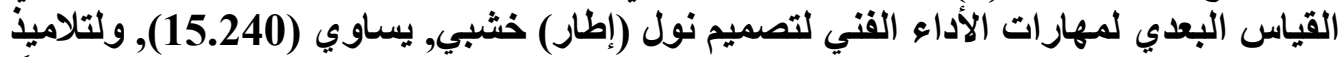

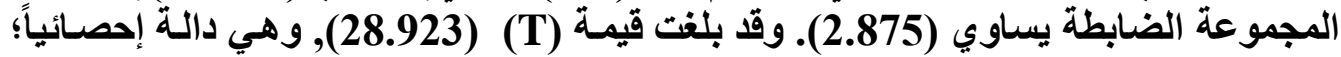

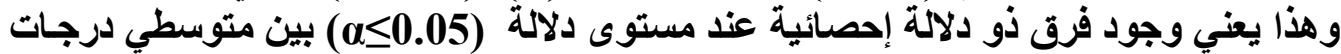
تلاميذ المجموعتين التجريبية والضابطة في التطبيق البعدي لبطاقة الملاحظة لمهـار آت الأداء

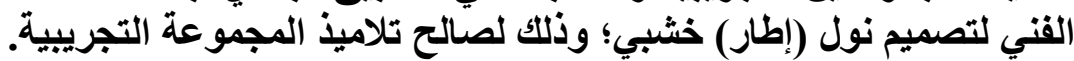

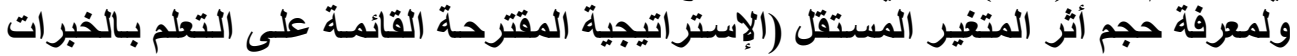

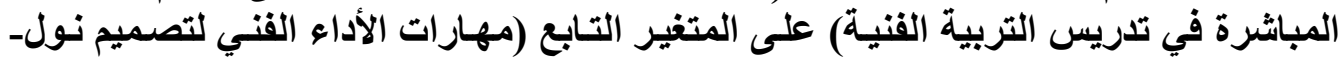

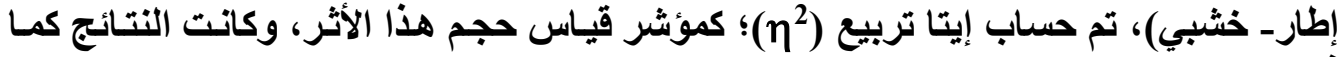
في الجدول (7) التالي.

\section{جدول7:}

حجم وتأثير فاعلية الإستراتيجية التدريسية المقترحة في تتمية مهارات الأداء الفني لتصميم نول(إطار) خشبي 


\begin{tabular}{|c|c|c|c|c|}
\hline بالخبرات & 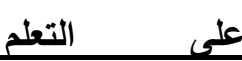 & قائمة & مقترحة & إستر اتيجية \\
\hline & & \multicolumn{3}{|c|}{ 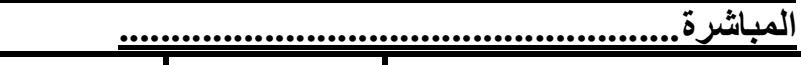 } \\
\hline 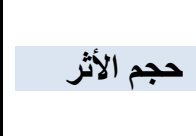 & 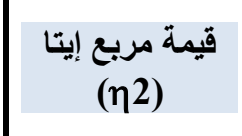 & المسابي البعديط & الحستوسي القبلي & مهارات الأداء الفني \\
\hline كبير & 0.976 & 15.240 & 2.760 & لتصميم نول(إطار) خشّبي \\
\hline
\end{tabular}

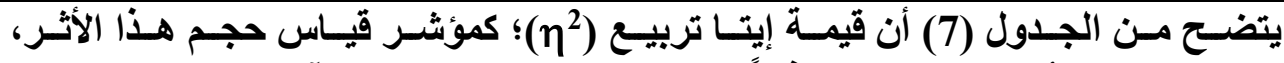

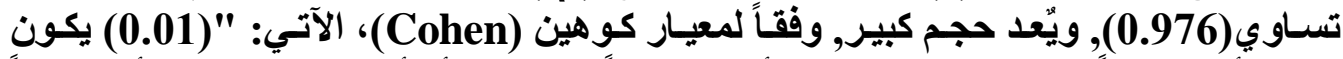

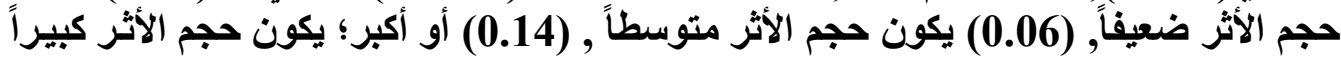

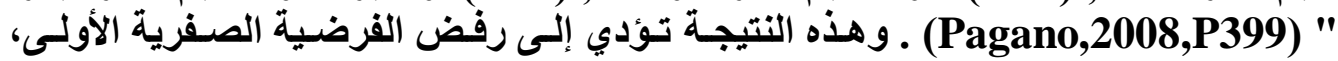

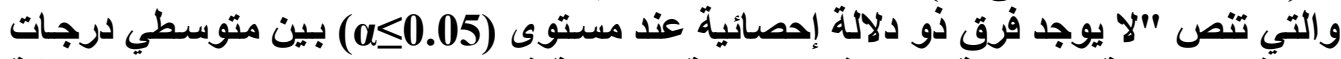

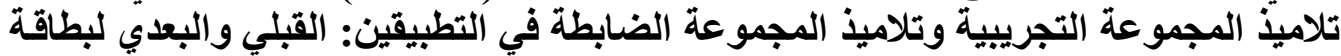

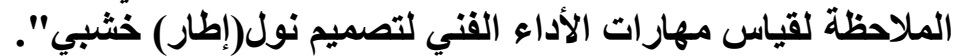

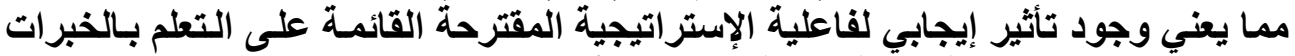

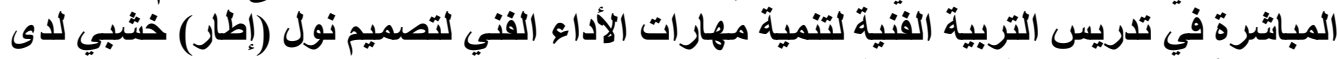
التلاميذ أفراد المجموعة تورينة التجريبية.

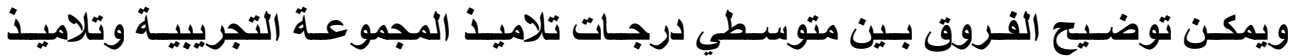

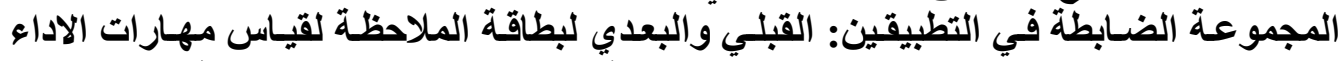

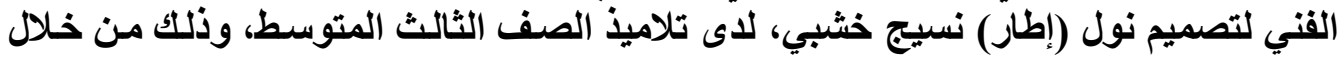

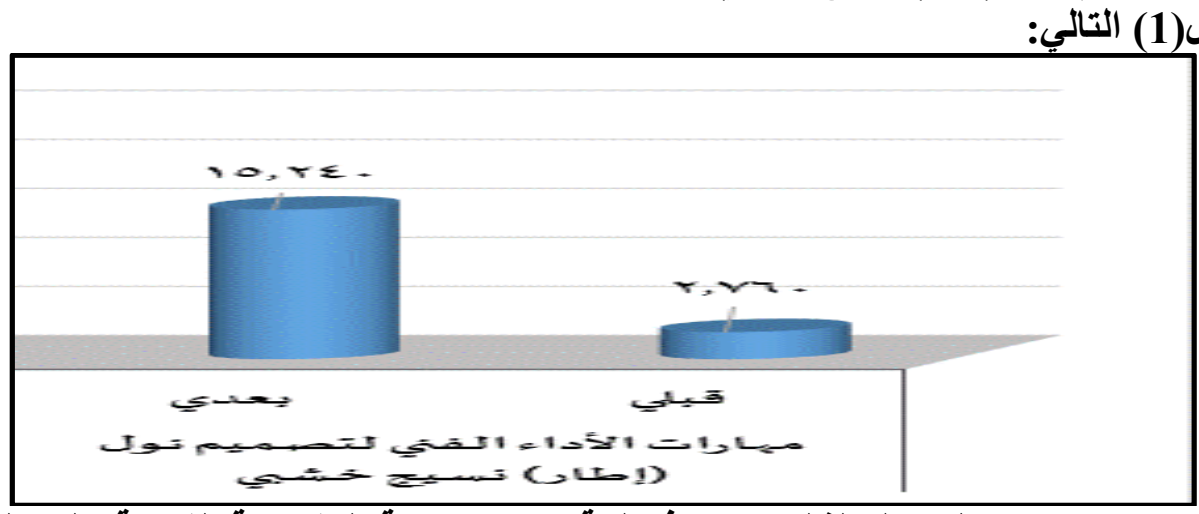

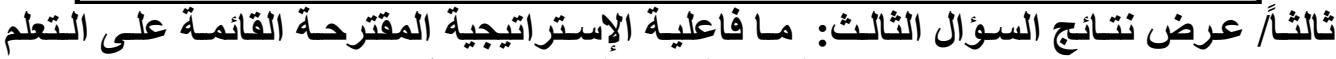

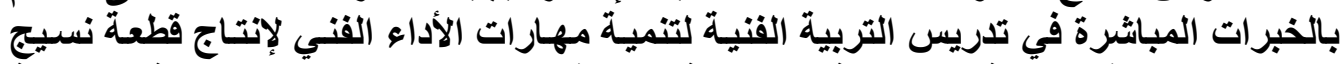

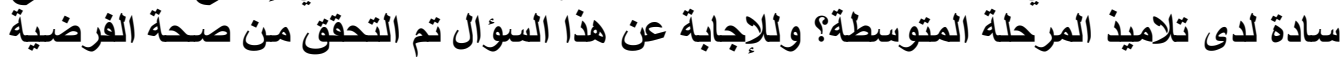

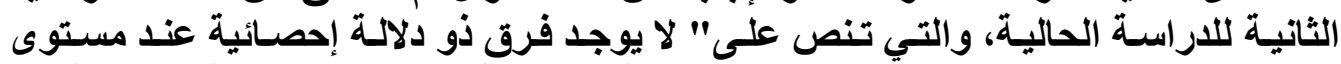

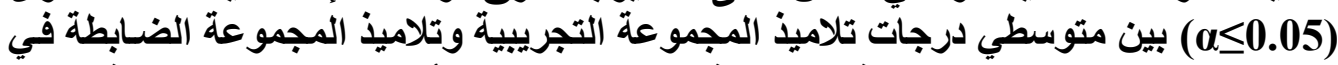

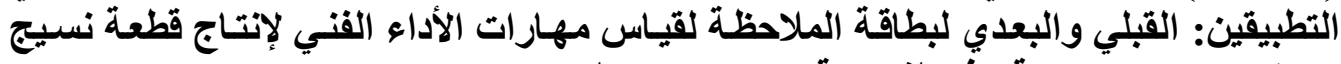

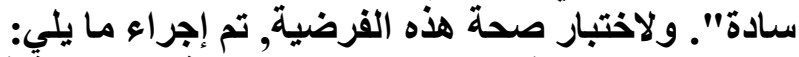

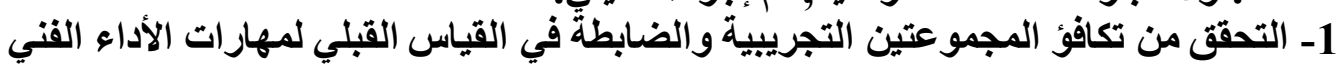
لإنتاج قطعة نسيج سنادة: 


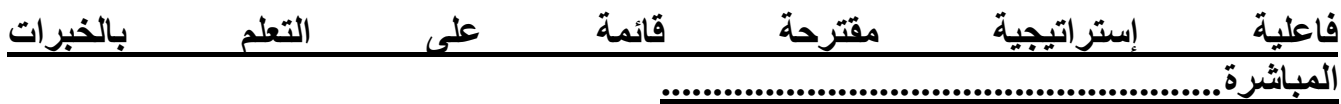

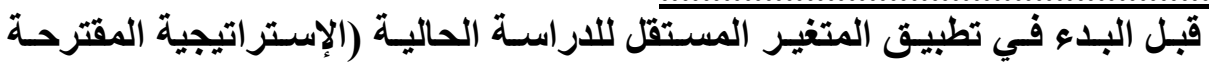

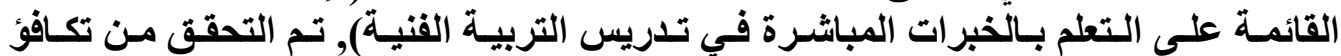
المجموعتين التجريبية والضابطة في الاختبار القبلي لمهارات الأداء الفني لإنتاج قطعة نسيج

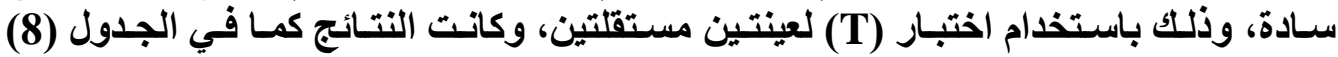
التالىي.

\section{جدول8:}

نتائج اختبار(T) لعينتين مستقلتين للمقارنة بين متوسط درجات تلاميذ المجموعتين التجريبية والضابطة في

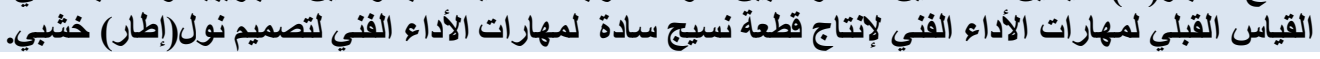

\begin{tabular}{|c|c|c|c|c|c|c|c|}
\hline الإحصائية & الحرية & $\begin{array}{l}\text { قيمة } \\
\text { (T) }\end{array}$ & الانعراف & المستوسطي & العدد & المجموعة & المقارنة \\
\hline \multirow{2}{*}{0.990} & \multirow{2}{*}{47} & \multirow{2}{*}{0.102} & 1.382 & 5.080 & 25 & التجريبية & \multirow{2}{*}{ لإنتاج قطعة نسيج سأدية } \\
\hline & & & 1.233 & 5.042 & 24 & الضابطة & \\
\hline
\end{tabular}

يتضح من الجدول (8) أن المتوسط الحسابي لارجات تلاميذ المجموعة التجريبية يسـاوي

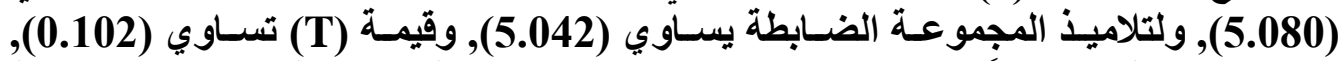

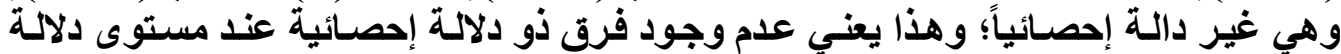

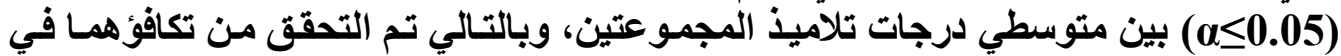

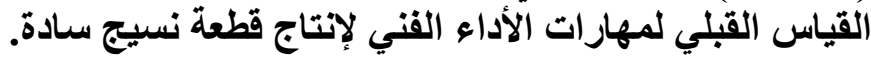

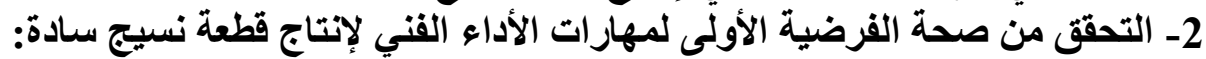

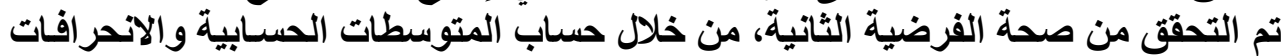

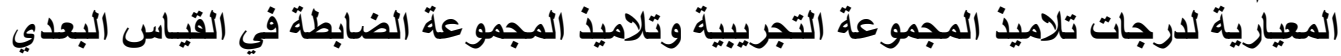

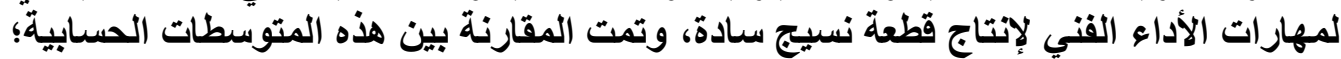

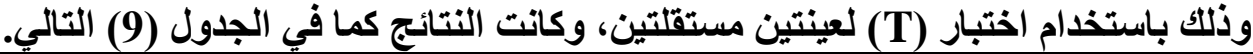

\begin{tabular}{|c|c|c|c|c|c|c|c|}
\hline التجريبية & لمجمو. & جإن تلامياً & ن & بذ للمقارذ & قياس & ضابطة فينتير & نتائج اختبا \\
\hline الإحصائية & الرجات & قيمة (T) & الالمعرياري & الحستوسط & العدد & المجموعة & المقارنة \\
\hline \multirow{2}{*}{0.01} & \multirow{2}{*}{47} & \multirow{2}{*}{24.643} & 3.727 & 25.160 & 25 & التجريبية & \multirow{2}{*}{ مهار مهات الإنتاج } \\
\hline & & & 1.139 & 5.583 & 24 & الضابطة & \\
\hline
\end{tabular}

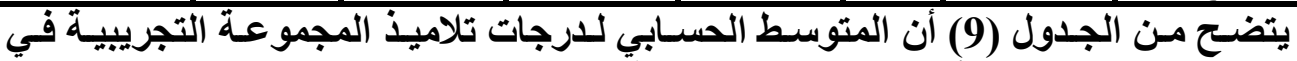

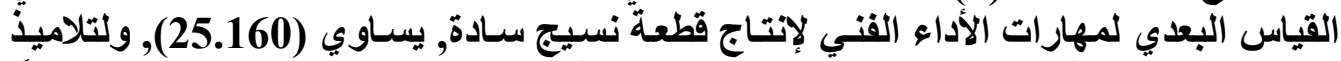

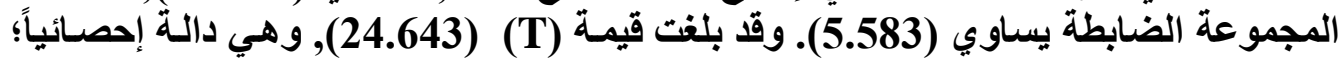

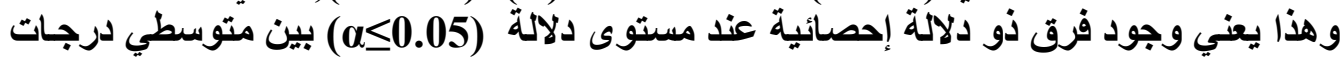




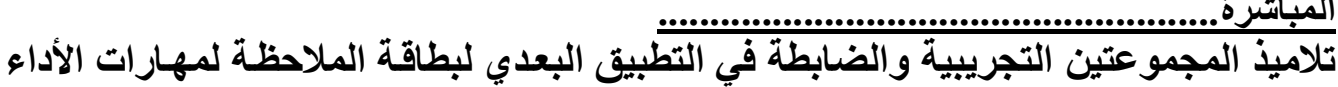

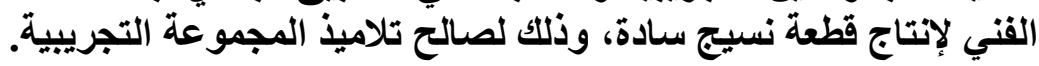




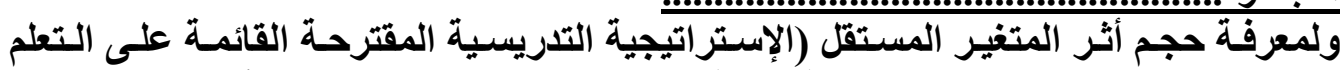

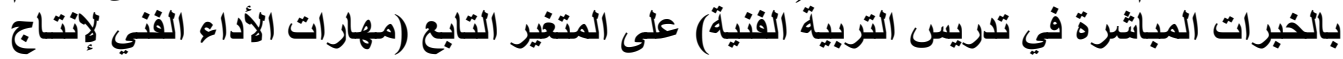

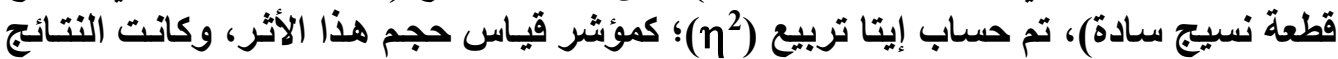
كما في الجدول (10) التبالي.

\begin{tabular}{|c|c|c|c|c|}
\hline \multicolumn{5}{|c|}{ 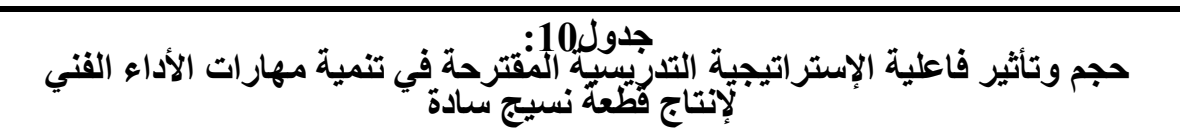 } \\
\hline حجم الأثر & قايتياة مربع & البمستوسي & المتّبطيط & مهارات الأداء الفني \\
\hline كبير & 0.966 & 25.160 & 5.080 & مـارات الإنتاج قطعة نسيج سناءدة الفني \\
\hline
\end{tabular}

يتضح من الجدول (10) أن قيمة إيتا تربيع (10)؛ كمؤشر قياس حجم هذا الأثر، تسـاوي

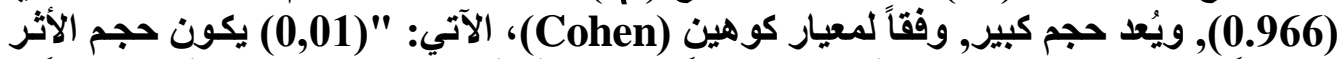

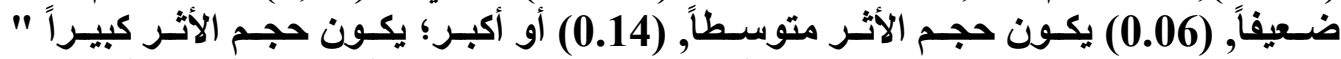

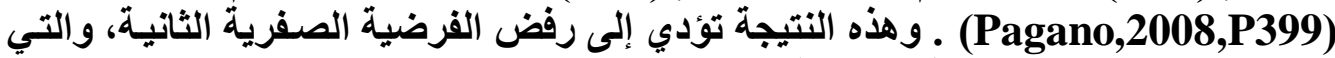

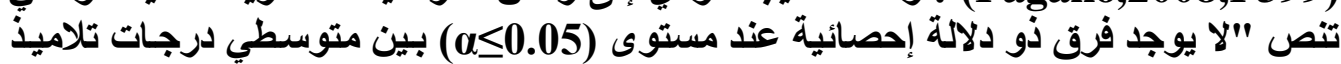

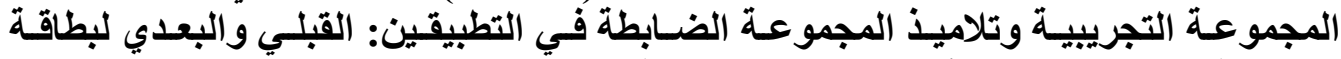

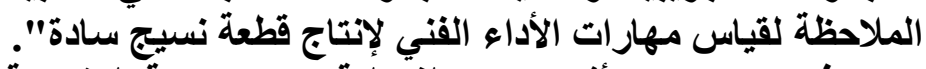

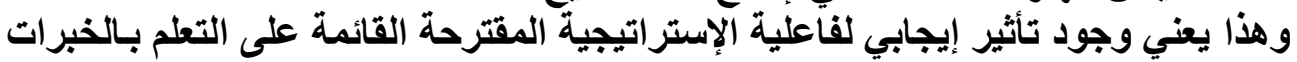

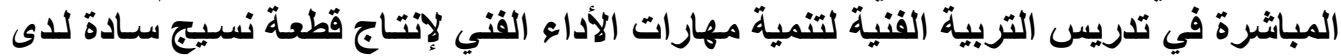
التلاميذ أفراد المجموعة توريس التجريبة التبية.

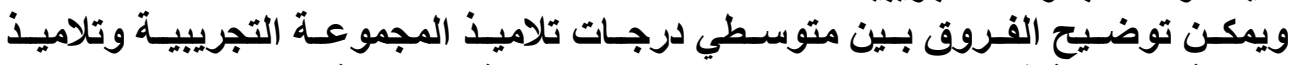

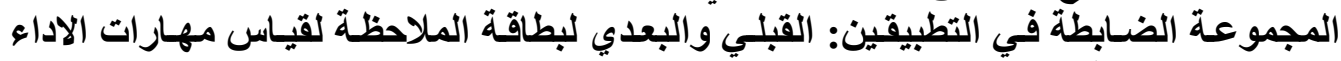

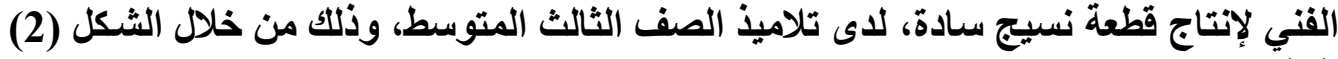
التالي:

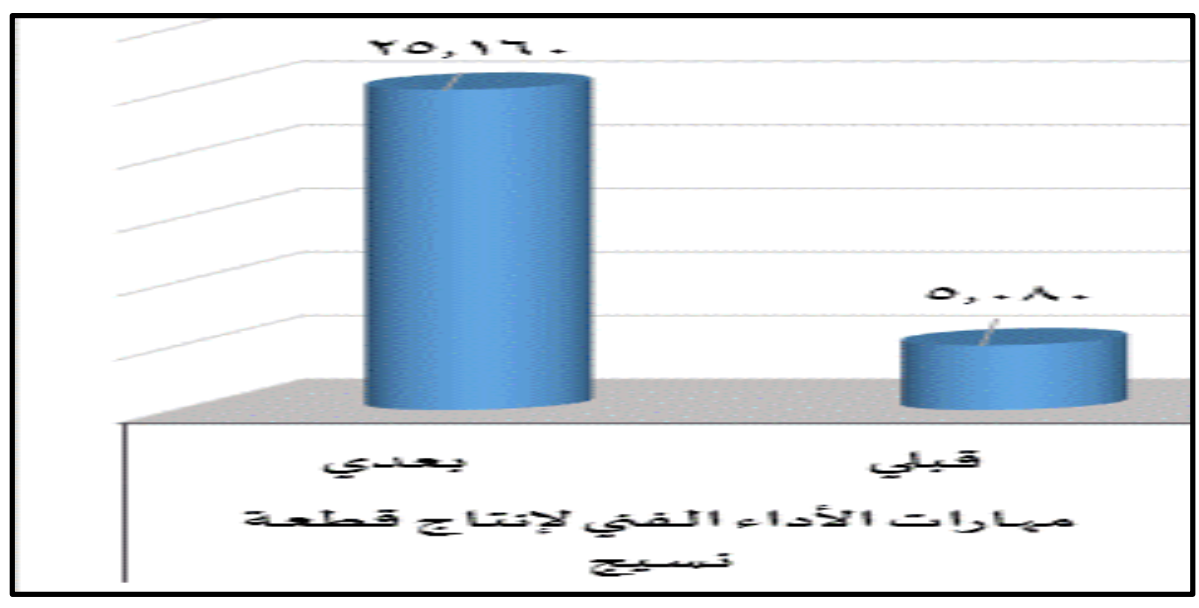




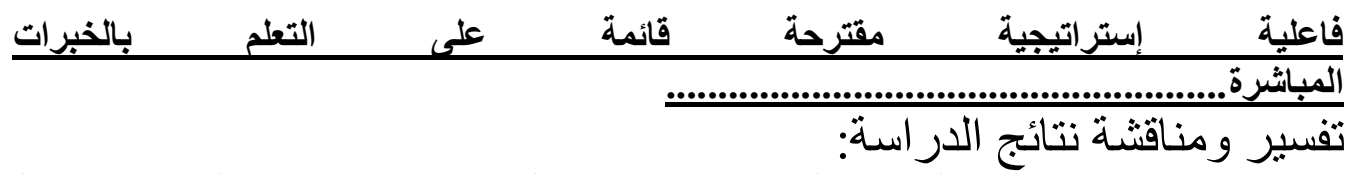

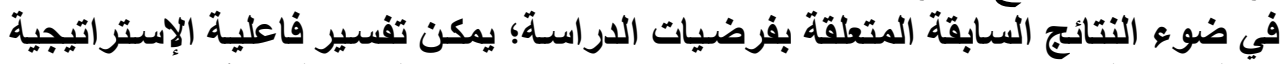

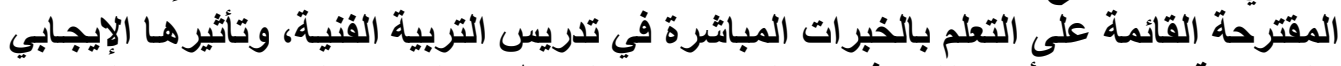

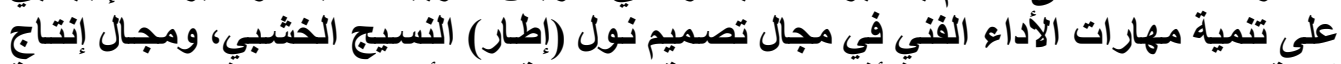

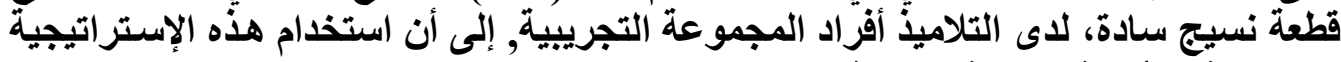

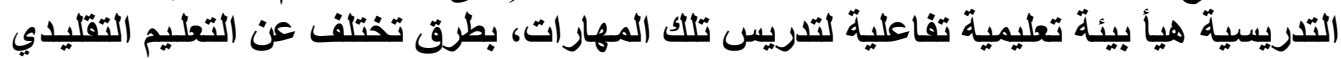

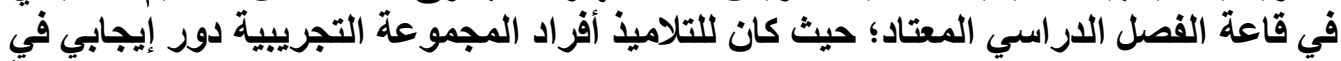

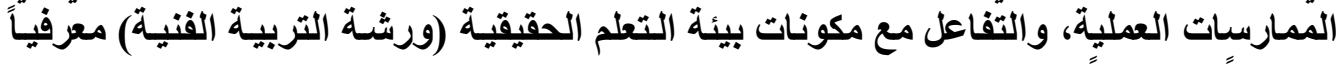
ومهارياً ووجدات النياً.

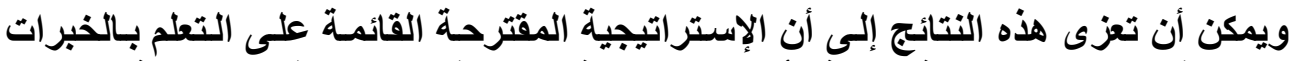

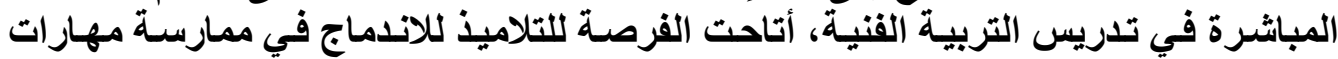

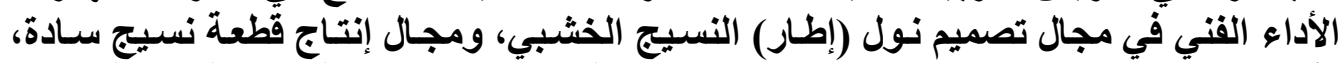

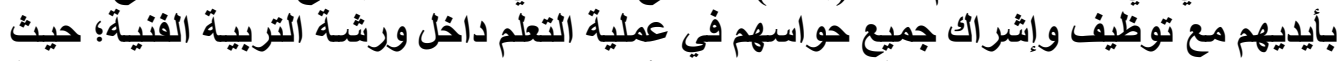

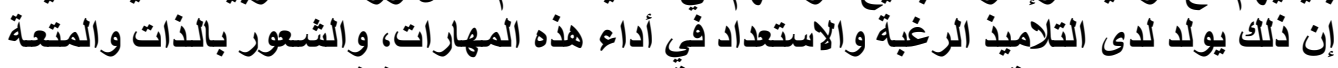

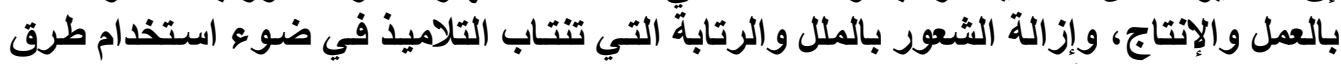

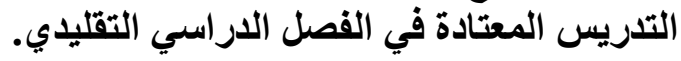




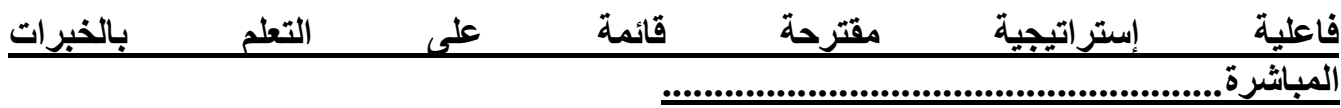

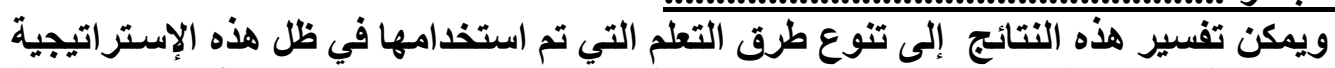

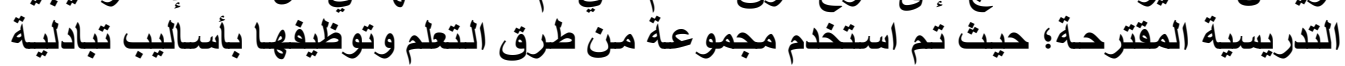

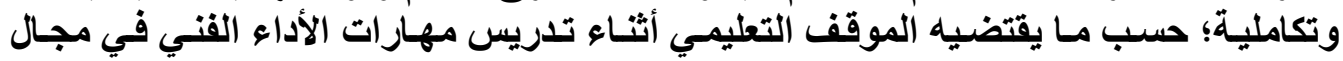

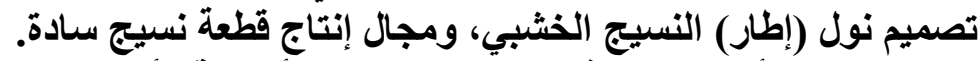

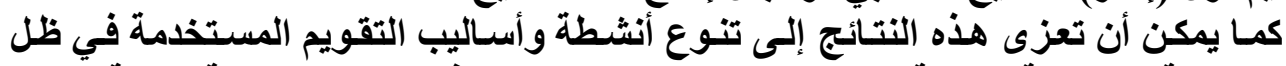

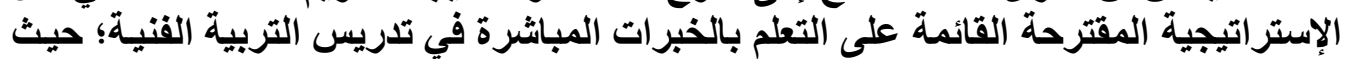

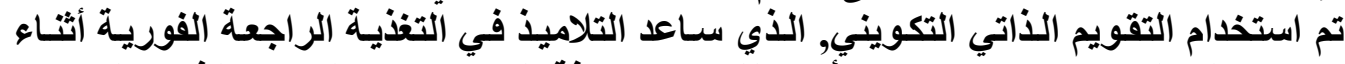

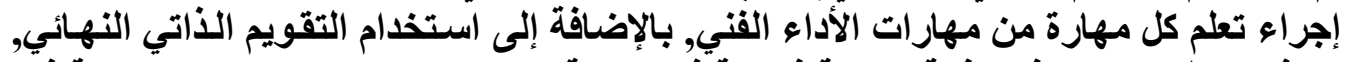

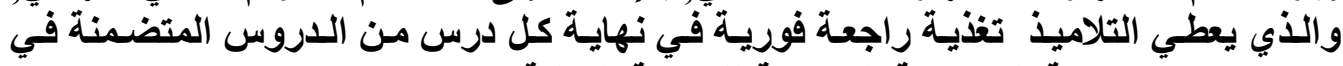

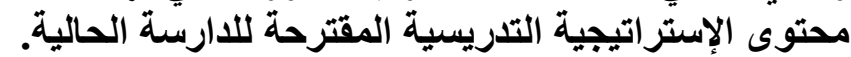

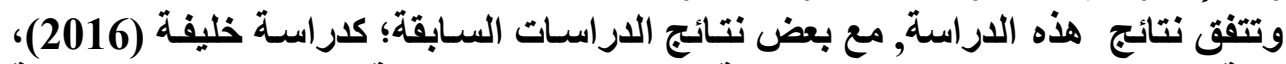

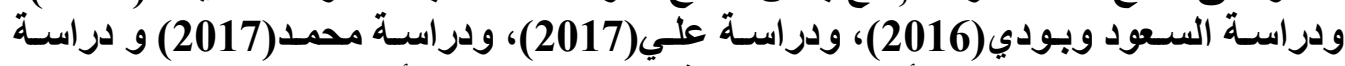

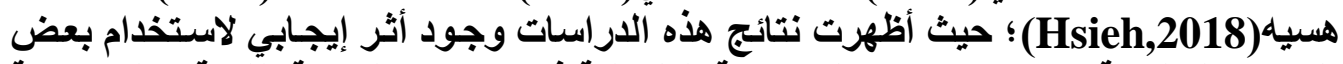

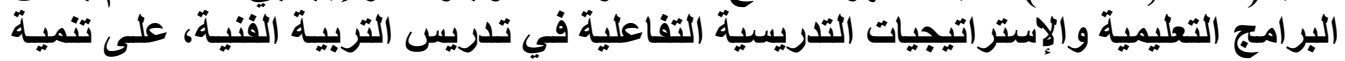

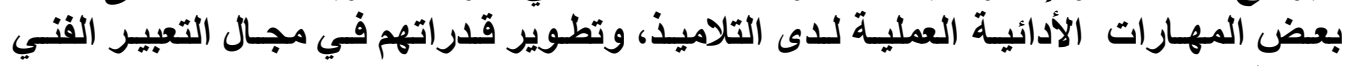

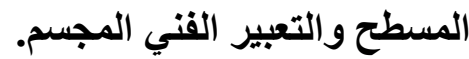
ملخص نتائج الدر أسة: 1- وجود أثر إيجابي لفاعلية الإستراتيجية المقترحة القائمة على التطلم بالخبرات المباشرة في

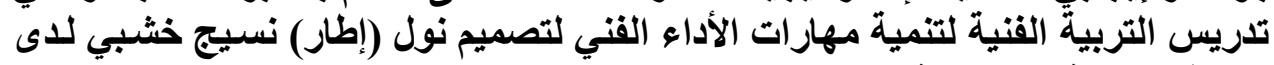
تلاميذ المرحلة المتوسطة. 2- وجود أثر إيجابي لفاعلية الإستراتيجية المقترحة القائمة علي التعلم بالخبرات المباشرة في

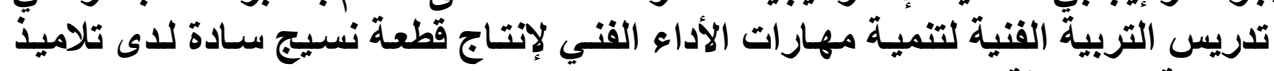
المرحلة المتوسطة. 
في ضوء ما توصلت إليه الدراسة من نتائج , يمكن تقديم التوصيات الآتية :

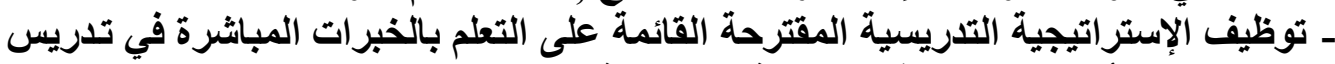

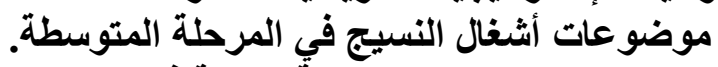

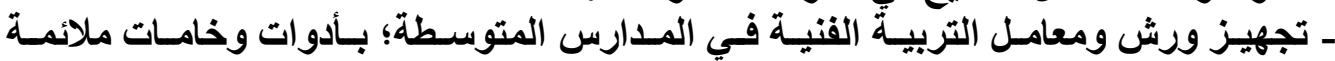

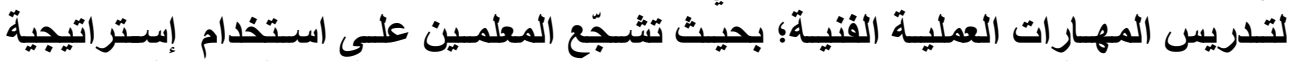

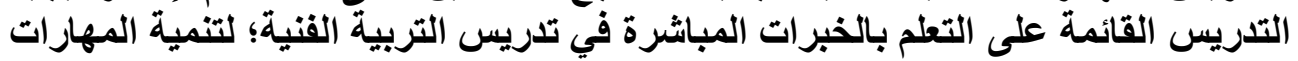
الأدائية في جميع مجالات التمانية التربية الفنية العملية العبية.

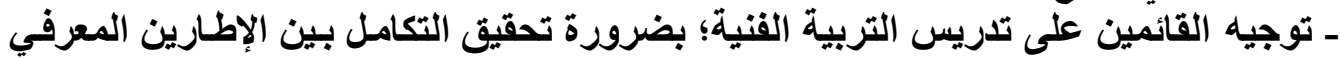

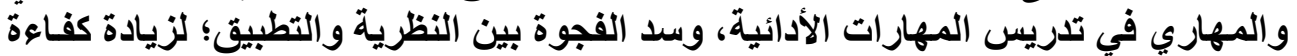
تذريس المهارّات الأدائية الفنية.

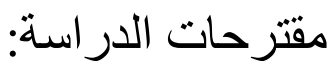

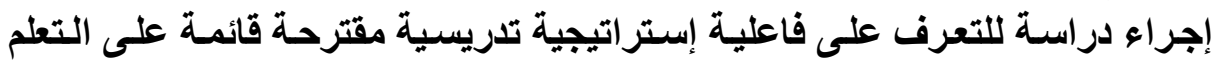

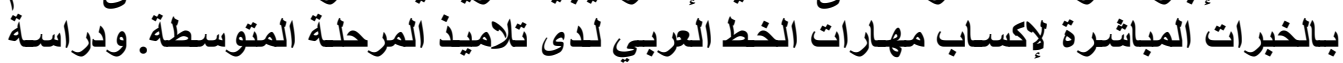

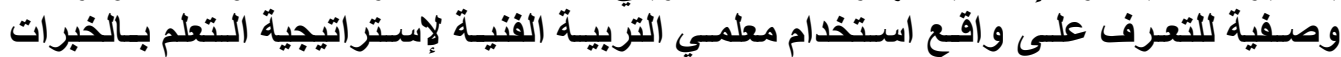
المباشرة في تدريس مجالات الفنون التطبيقية في المرحلة المتوسطة. 


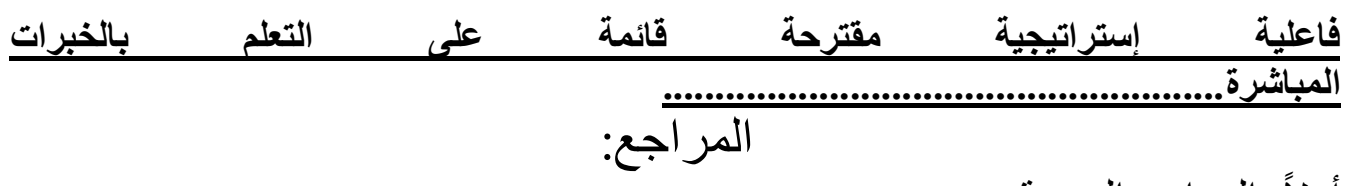

أولاً: المر اجع العربية:

ـ أبو شعالة، حسين ميلاد(2016). الأشغال الفنية ودور هـا في تنميـة الرؤيـة الجماليـة لدى الطفل. مجلة الكية

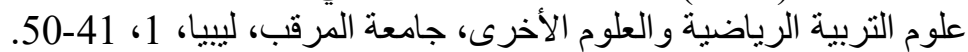

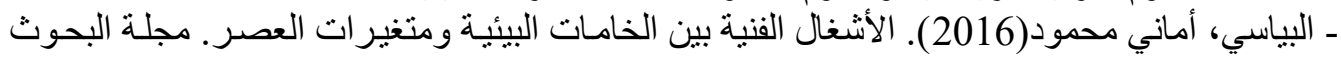

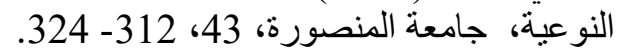

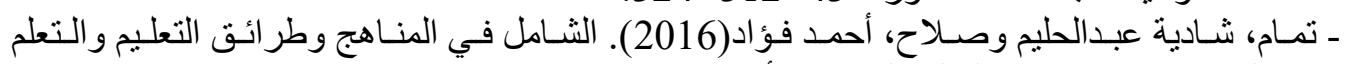
الحديثة. مركز ديبونو لتعليم التفكير : الأردن.

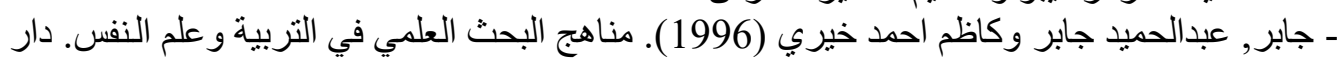

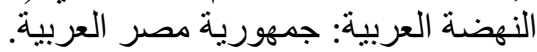
ـ حسين، عبدالمنعم خيري(2013). القياس والتقويم في الفن و التربيـة الفنية. مركز الكتاب الأكاديمي للنشر و التوزيع: الأرّن:

ـ الحيلة، محمد محمود (2008). التربية الفنية وأساليب تدريسها. دار المسيرة للنشر و التوزيع: الأردن. ـ خليفة، حسن محمد حويل(2016). فاعلية برنامج قائم على إستر اتيجيات التعلم المنظم ذاتياً في تميـة

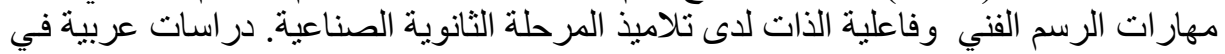

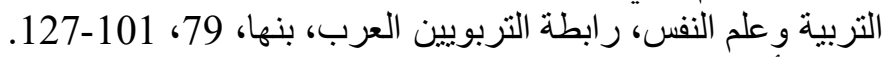

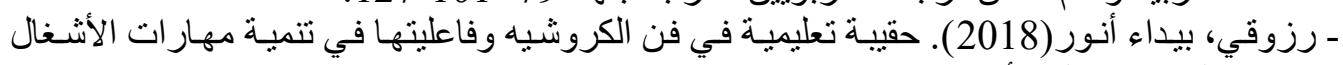

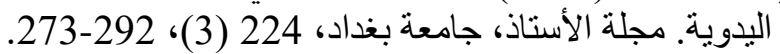

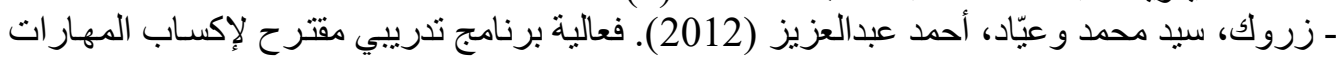

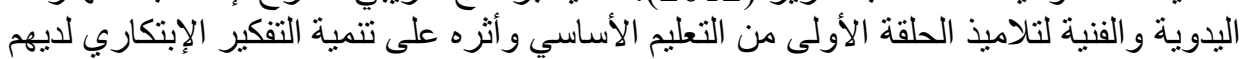

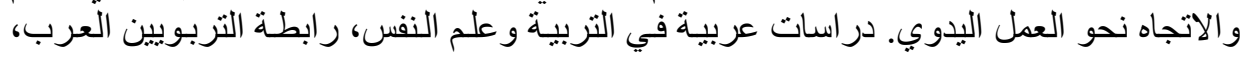

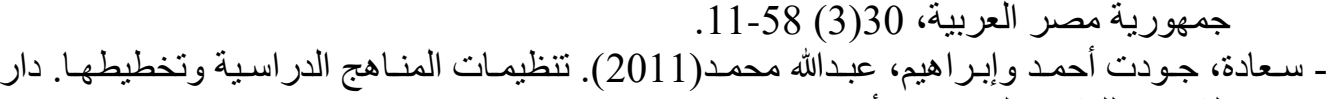
الشروق للنشر و التوزيع: الأردن.

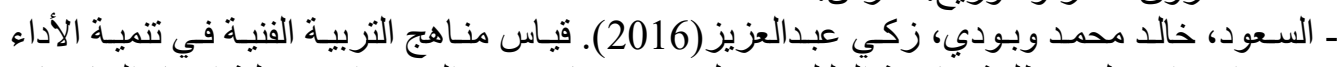

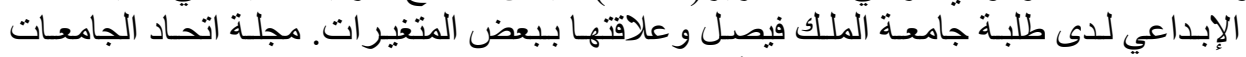

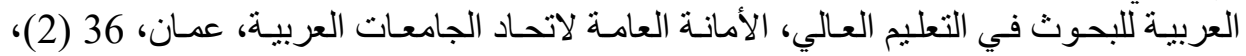
$217-201$ ـ شحاته، حسن و النجار، زينب(2011). معجم المصطلحات التربوية والنفسية. الدار المصرية اللبنانية: جمهورية مصر العربية ولنجانية ـ شحاته، حسن(2016). أساسيات التعليم و التعلم توجهات حديثة وتطبيقاتها. دار العالم العربي للنشر والتوزيع: جمهورية مصر العربية.

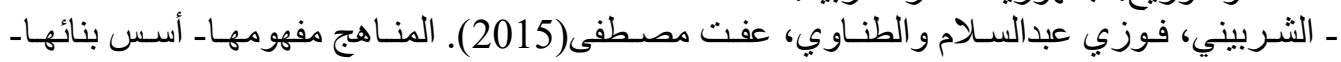

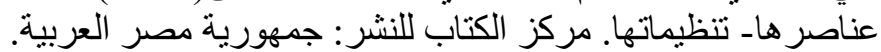

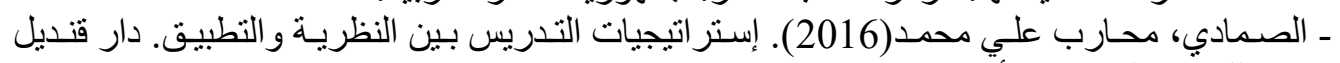

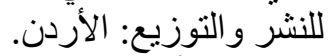
ـ طعيمة، رشدي أحمد وآخرونيع: آلاردن. دار المسيرة للنشر و التوزيع: الأردن. 
- عبدالقادر، أمينة محمد إبر اهيم(2014). فاعلية برنامج مدار بالحاسوب قائم على المهار الات الفنية في

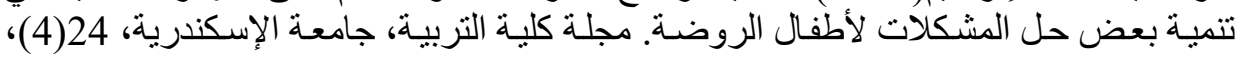

ـ علي، زينب محمود أحمد(2017). فاعلية استخدام إستراتيجية قبعات التفكير الست في تدريس التربيـة

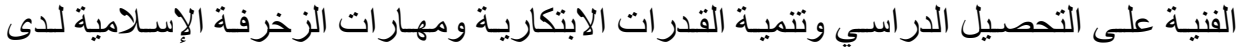

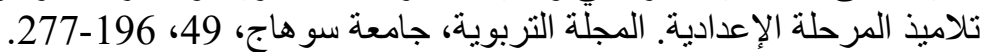

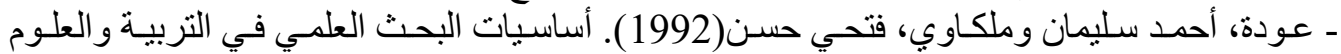
الإنسانية. مكتبة الكتاني: الأردن.

ـ الغريب, رمزية (1996). التقويم والقياس النفسي و التربوي. مكتبة الأنجلو المصرية: جمهورية مصر

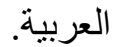
ـ فان دالين، ديوبولد(2010). مناهج البحث في التربية و علم النفس. ترجمة محمد نبيل نوفل و آخرون.

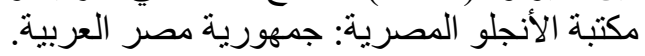

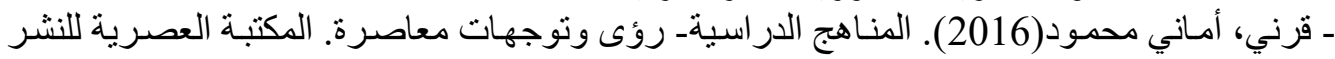
والتوزيع: جمهورية مصرد العربية.

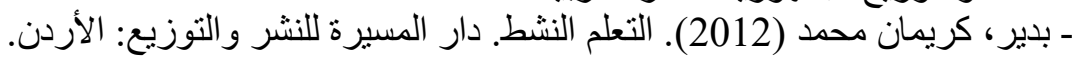

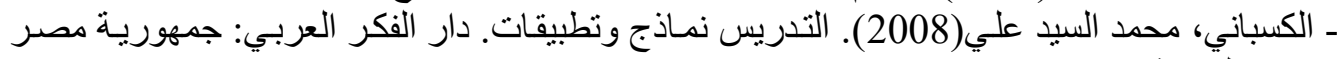

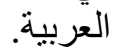
ـ اللقاني، أحمد حسين و الجمل، علي أحمد(2013). معجم المصطلحات التربويـة المعرّفة في المنـاهج وطرق التدريس. عالم الكتب: جمهورية مصر العربية العربية. ـ مبروك، فرج(2016). الأنشطة المدرسية وتطبيقاتها. دار حميثر اللنشر و التوزيع، جمهورية مصر

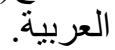
ـ محمد، زياد هاشم(2017). فعالية نظرية الخبرة على إتقان الأداء المهاري لطلبة قسم التربية الفنية في

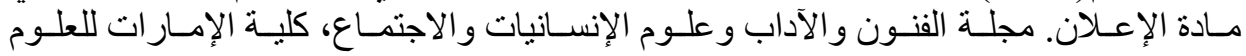

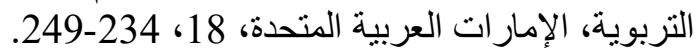

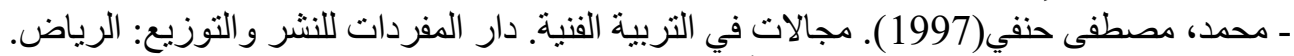

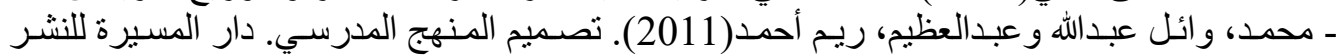
والتوزيع: الأردن.

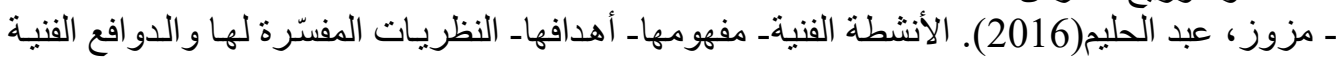

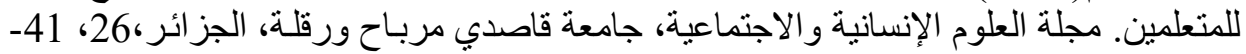
.50 ـ المسعري، ناصر عبدالله(2009). مناهج وطرق تدريس التربية الفنية و اتجاهاتها الحديثة في التعليم العام. دار الصميعي للنشر والتوزيع: الرياض.

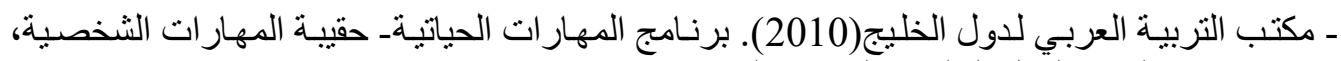
مكتب التربية لدول الخليج العربي: الرياض. ـ المؤتمر الدولي لتقويم التعليم(2018، ديسمبر ). مهار ات المستقبلـ تنمينها وتقويمها. هيئة تقويم التعليم

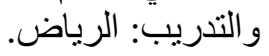

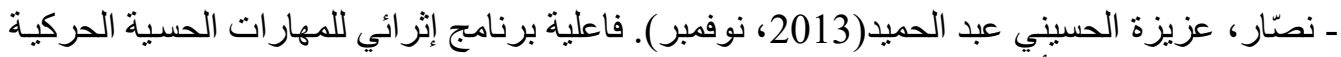

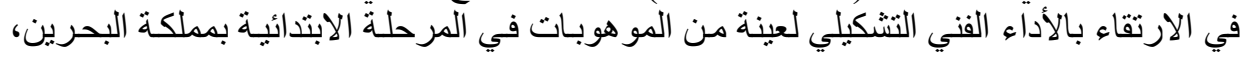

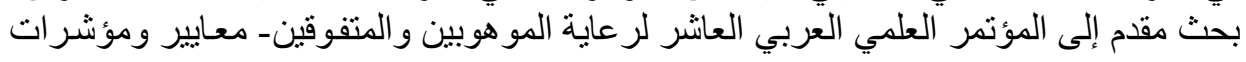




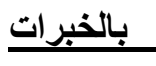

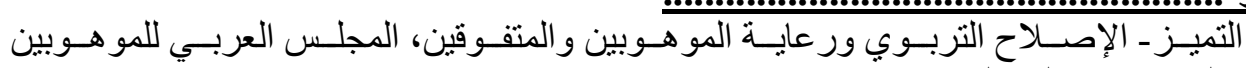

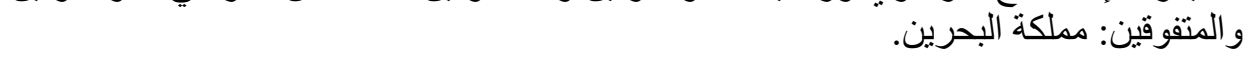
ـ الهنداوي، علي فالح(2014). علم نفس النمو و الطفولـة والمر اهقة. دار الكتاب الجامعي: الإمـار ات العربية المتحدة. ـ الوكبل، حلمي أحمد، و المفتي، محمد أمين(2015). أسس بنـاء المنـاهج الدراسية وتنظيماتها. دار

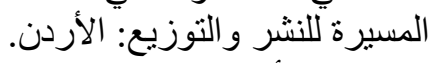
ثانيا: المر اجع الأجنبية:

- Bailey, E.(2018). Using Culturally Relevant Experiential \& Leonard, J., Holifield., Q., Moore,C., Education to Enhance Urban Children's Knowledge and Engagement in Science. Journal of Experiential Education, 41(2), 137-153.

- Burke, A.(2019). Mokyklos Estetines Ugdymo(si) Aplinkos Ir Mokiniu Menines Saviraiskos Sasajos. Journal Acta Paedagogica Vilnensia, 42, 99-128.

- Hsieh, C.(2018). Developing Design through a Creative Problem-Solving Process- A Group Community Art Project. The International Journal Of Art \& Design Education, 37(3), 541-554.

- Hursen, C., \& Islek., D.(2017). The Effect Of A School-Based Outdoor

Education Program On Visual Arts Teachers' Success And SelfEfficacy Beliefs. South African Journal of Education,37(3), 1- 17.

- Lvon, H., \& Kuscevic, D.(2013). School and the Cultural-Heritage Environment: Pedagogical, Creative and Artistic Aspects. Center for Educational Policy Studies Journal, 3(2), 29-50.

- Pagano, R. (2008). Understanding Statistics in the Behavioral Sciences. $9^{\text {th }}$ Edition. Belmont, Ca: Wadsworth.

- Ruokonen, I.(2018). 'I - from dreams to reality': A Case Study of Developing Youngsters' Self-Efficacy and Social Skills through an Arts Educational Project in Schools. The International Journal Of Art \& Design Education, 37(3),480-492.

- The 3rd International Conference.(2019, March). on Culture, Education and Economic Development of Modern Society. The International Science and Culture Center for Academic Contacts -ISCCAC-, Moscow, Russia. 